\title{
Fictions of the gift: Generosity, obligation, and economy in eighteenth-century England
}

Cynthia J. Klekar

West Virginia University

Follow this and additional works at: https://researchrepository.wvu.edu/etd

\section{Recommended Citation}

Klekar, Cynthia J., "Fictions of the gift: Generosity, obligation, and economy in eighteenth-century England" (2005). Graduate Theses, Dissertations, and Problem Reports. 2315.

https://researchrepository.wvu.edu/etd/2315

This Dissertation is protected by copyright and/or related rights. It has been brought to you by the The Research Repository @ WVU with permission from the rights-holder(s). You are free to use this Dissertation in any way that is permitted by the copyright and related rights legislation that applies to your use. For other uses you must obtain permission from the rights-holder(s) directly, unless additional rights are indicated by a Creative Commons license in the record and/ or on the work itself. This Dissertation has been accepted for inclusion in WVU Graduate Theses, Dissertations, and Problem Reports collection by an authorized administrator of The Research Repository @ WVU.

For more information, please contact researchrepository@mail.wvu.edu. 


\title{
FICTIONS OF THE GIFT: GENEROSITY, OBLIGATION, AND ECONOMY IN EIGHTEENTH-CENTURY ENGLAND
}

\author{
Cynthia J. Klekar \\ Dissertation submitted to the \\ Eberly College of Arts and Sciences \\ at West Virginia University \\ in partial fulfillment of the requirements \\ for the degree of \\ Doctor of Philosophy \\ in \\ English \\ Robert M. Markley, Ph.D., Chair \\ Marilyn Francus, Ph.D. \\ John Lamb, Ph.D. \\ Johnathan Burton, Ph.D. \\ Beth Kowaleski-Wallace, Ph.D. \\ Department of English \\ Morgantown, West Virginia \\ 2005
}

Keywords: Eighteenth-century, British novel, Gift Economy, Trade, Property, Gender

Copyright 2005 Cynthia J. Klekar 


\title{
ABSTRACT \\ FiCTIONS OF THE GIFT: GENEROSITY, OBLIGATION, AND ECONOMY IN EIGHTEENTH-CENTURY ENGLAND
}

\author{
Cynthia J. Klekar
}

Fictions of the Gift: Generosity, Obligation, and Economy in Eighteenth-Century English Literature examines the relationship between generosity, obligation, economy, and the gift in eighteenth-century English literature and culture. The central inquiry of the project investigates the paradoxical nature of the gift and ways in which the politics of a gift economy informed both practical and symbolic relations of domination in the period. Given the widespread nature of the language of the gift in the period, I concentrate on cultural texts and eighteenthcentury novels to demonstrate the work of the gift within a number of eighteenth-century institutions, such as international trade, diplomacy, property, marriage, and the family. By analyzing representations of gift economies in social and literary texts, such as Lord George Macartney's China journal, Daniel Defoe's Roxana, Henry Fielding's Tom Jones, and Frances Burney's Cecilia, I demonstrate how the fiction of the disinterested gift underwrites a number of the period's social and economic concerns. Drawing on the work of Marcel Mauss, George Bataille, Pierre Bourdieu, Jacques Derrida, and Marshal Sahlins, I locate a specific ideology of the gift during the eighteenth century. The gift serves an ideological purpose specific to the eighteenth century and emerges as a way to ameliorate the conflicts that arose as the patronage system waned and capitalism and individualism became more prominent and seemingly threatened socioeconomic hierarchies. In this respect, the gift becomes a way to maintain relations of domination in a period in which forms of domination were being challenged and changed. Although eighteenth-century texts do not represent a gift economy as the primary system of exchange or acquisition of wealth, the language of the gift nevertheless is adopted simultaneously to disguise and to describe the harsh realities of profit, obligation, and domination by depicting a symbolic exchange of loss. The gift enacts the affective bonds of the patronage system--of equal and mutual favor and return--but paradoxically functions to mask the amorality of self-interest and manipulation. The narrative of the gift in the eighteenth century substitutes for the explicit relations of competitive capitalist exchange an implicit and seemingly disinterested ethos of mutual benefit. 


\section{TABLE OF CONTENTS}

\section{Chapter One:}

Gifts, Obligation, and Economy

in the "Age of Benevolence"

II. Chapter Two:

"Prisoners in Silken Bonds": Obligation, Trade, and Diplomacy in English Voyages

to Japan and China

\section{Chapter Three:}

"Comply and Live, Deny and Starve":Obligation

and Asymmetrical Exchange in Defoe's Roxana

IV. Chapter Four:

Property, Legitimacy, and Socioeconomic Debt:

The Misrecongized Gift in Tom Jones

V. Chapter Five:

'Her Gift Was Compelled': Gender

and the Failure of the 'Gift' in Cecilia

Works Cited 


\title{
Chapter ONE
}

\section{Gifts, Obligation, and Economy in the "Age of Benevolence"}

\begin{abstract}
I.
In the closing act of Congreve's The Way of the World, Mrs. Fainall presents a "gift of deed" to Mirabell, and enacts an important transition within the rhetoric of gift-giving from an ethos of aristocratic patronage to a complex and on-going negotiation of value. ${ }^{1}$ This exchange is emblematic of the continual and often problematic transformation of social values in the eighteenth century. In this dramatic moment, Fainall, who represents an economy of honor and patronage (he has married both for money and to blackmail Lady Wishfort to hand over more), is displaced by Mirabell, who represents the new economy based on a utilitarian ethic of mutual exchange and contractual obligation. ${ }^{2}$ Thus, in the presentation of the gift, the play dramatizes the emerging legitimacy of contractual relations underpinning social authority and economic power, as well as Mirabell's skill in using his emotional and gender-based power over Mrs. Fainall, his
\end{abstract}

\footnotetext{
${ }^{1}$ William Congreve, The Way of the World, ed. Brice Harris, Restoration Plays, (New York, NY: The Modern Library, 1953) 592.

${ }^{2}$ The complexities of social and economic transition dramatized in The Way of the World are discussed in further detail by Richard Braverman, "Capital Relations and The Way of the World," ELH 52.1 (1985): 133-58.
} 
former mistress, to prosper in his efforts to marry Millamant. The hero's ultimate control of interpersonal and legal relationships is cast in a language of gift, debt, and obligation that becomes increasingly important later in the eighteenth century. The gift of deed that Mrs. Fainall signs over to Mirabell is indeed in the form of a "gift" that both invokes obligations and is the product of her obligation to her former lover. The gift is represented both as property that can be exchanged and as an embodiment of reciprocity between giver and receiver. Rather than entailing obligations of honor and service, the "gift of deed" represents the enactment of capitalist relations in the form of gift exchange, thereby concealing the negotiation process and the power relations bolstered by the exchange. Significantly, Congreve leaves the audience in the dark about the existence of Mrs. Fainall's gift of deed to her former lover until Act 5. What seems to be a Machiavellian strategy on Fainall's part has been rendered irrelevant from before the start of the play because Mrs. Fainall's "gift" both empowers Mirabell and effectively compels her to aid him in his designs on Millamant. In this sense, Fainall's impotence emphasizes the fall of courtly obligation and the rise of capital relations. This scene and the play overall mark an acknowledgment of the shift in eighteenth-century social, political, and economic conceptions of debt and obligation. 
I draw on this scene from Congreve's play in order to situate the argument of my dissertation historically. My contention is that the anxieties and conflicts that accompanied the cultural and economic changes in the period were dealt with, in literary works, by manipulating the language and practice of gift economy. As Fainall's fate suggests, the patronage system in 1700 was succumbing to a competitive, market-based economy. Fainall relies on a traditional system that regulates the transmission of landed property--property follows the legal ties of marriage and blood. He expects to triumph because he believes he can coerce both daughter and mother. Mirabell, on the other hand, represents a system of innovation and status mobility, consummate with the settlement of 1688 which recognized the sovereignty of parliament as well as the prerogatives of property. Thus, the gift exchange permits him to redefine the terms of an old social order within the context of a new economy. Mirabell's new way of looking at the world stresses the legalization of the prerogative will, the limitations of heroic and courtly conventions, and the triumph of the legal document and negotiated settlement. Such negotiations, however, are always asymmetrical and always reassert unequal distributions of power and property. The future Mrs. Fainall doesn't give Mirabell her estate solely because she loves him; fearing that she is pregnant with his child, she is coerced by him into marrying "a false and 
designing lover" and signs her gift of deed over to him to protect the land and her income from her future husband.

In this sense, the asymmetry of gift exchange characterizes the action of the play: the exchange of women in the play is disguised by the exchange of gifts, and the commodification of Mrs. Fainall and Millamant is recast in a language of generosity, complicity, and love for love. The significance of this scene is that it recalls a generosity and affective giving that characterized idealized depictions of the aristocratic patronage system in medieval and renaissance societies, but in actuality perpetuates a competitive, market-based system that should benefit women and the lower classes; however, in actuality the gift subverts this possibility through a seemingly selfless gift exchange that creates new relations of obligation and reinforces traditional ones.

\section{II.}

Fictions of the Gift: Generosity, Obligation, and Economy in Eighteenth-Century English Literature locates a specific ideology of the gift during the complex transition from a hierarchical feudal order to one of economic exchange based on credit and contract. ${ }^{3}$ The gift serves an ideological purpose specific to the

\footnotetext{
${ }^{3}$ This shift has been documented in a number of ways by a number of critics. For representative examples, see J.G.A. Pocock, The Ancient Constitution and the Feudal Law: English Historical Thought in the Seventeenth Century (Cambridge: Cambridge University Press, 1957); Pocock, Politics, Language, and Time: Essays on
} 
eighteenth century and emerges as a way to ameliorate the conflicts that arose as the patronage system waned and capitalism and individualism became more prominent and seemingly threatened socioeconomic hierarchies. In this respect, the gift becomes a way to maintain relations of domination in a period in which forms of domination were being challenged and changed. Although eighteenth-century texts do not represent a gift economy as the primary system of exchange or acquisition of wealth, the language of the gift nevertheless is adopted simultaneously to disguise and to describe the harsh realities of profit, obligation, and domination by depicting a symbolic exchange of loss. The gift enacts the affective bonds of the patronage system--of equal and mutual favor and return--but paradoxically functions to further and mask the amorality of self-interest and manipulation. The narrative of the gift in the eighteenth century substitutes for the explicit relations of competitive capitalist exchange an implicit and seemingly disinterested ethos of mutual benefit. My dissertation examines the relationship between generosity, obligation, economy, and the gift in what I argue is a representation of a masculinist and often exploitative economy in eighteenth-century English literature. The central inquiry of the project investigates the paradoxical nature of the gift and

Political Thought and History (New York, NY: Antheneum, 1971); Christopher Hill, Puritism and Revolution (London: Secker and Warburgh, 1958); and Paul Langford, Public Life and the Propertied Englishman: 16891798 (Oxford: Clarendon Press, 1991). 
the ways in which the politics of a gift economy informed both practical and symbolic relations of domination in the period. Given the widespread nature of the language of the gift, I have chosen to concentrate on several important cultural texts and eighteenth-century novels to demonstrate the work of the gift within a number of eighteenth-century institutions, and the impact of the gift on conceptions of gender and class. I structure my argument chronologically, moving from an analysis of public institutions, such as international trade, diplomacy, and business, to an analysis of private institutions, such as property, marriage, and the family.

By analyzing representations of gift economies in social and literary texts, such as Macartney's China journal, Daniel Defoe's Roxana, Henry Fielding's Tom Jones, and Frances Burney's Cecilia, I demonstrate how the fiction of the disinterested gift underwrites a number of the period's social and economic concerns, such as authority, gender, labor, property, and marriage. I interrogate the assumption that gift exchange cultivates disinterested personal relations and explore how seemingly disinterested gestures, like Congreve's "gift of deed" in The Way of the World, bolster state, paternal, and filial authority in the eighteenth century. As England and Europe experienced profound economic transitions, the gift became a critical means by which to deflect the emerging confusion about 
origins, value, class, and property. It is my claim that the discourse of the gift both complicates and promises to work through these issues. In the literary representations I examine, the gift is used to transfer property, to disguise business as diplomacy, to displace notions of consumption and production, and to suture over the period's crisis in value, property, gender, courtship, and marriage. My concerns include also identifying the justifications for gifts in the period and the strategies used to valorize gift exchange. The concern in the eighteenth century with charitable giving, the upper class' preoccupation with regulating responsible charity for the protection of the state, and the exchange of women in marriage, point to a middle- and upper-class benevolence as the primary agent of a seemingly disinterested generosity. Although the writers of the period named theirs" an "Age of Benevolence," my dissertation suggests that an essentially hegemonic and paternal authority over charity and generosity recasts the period not as the age of benevolence, but as the age of obligation. ${ }^{4}$

Therefore, eighteenth-century literary critics must read the gift in the period not just as part of an on-going dialogue about social relations, but as a historically specific phenomenon directly related to the ways in which the period is

${ }^{4}$ Eighteenth-century writers who characterize the period as "The Age of Benevolence" and/or discuss the period's preoccupation with benevolence include David Hume, Adam Smith, The Earl of Shaftesbury, Henry Fielding, Daniel Defoe, Frances Hutchinson, Bernard Mandeville, Richard Price, and Jonathan Edwards. 
characterized. An analysis of gift exchange specifically in this period reopens many debates about the period and its legacy, both historically and in literary culture. I propose to show that the conception of the eighteenth century as the age of benevolence is inaccurate, that the agency women seemed to have gained in the period is much more limited than normally assumed due to modes of symbolic domination, and that in this period it is the gift, not capitalism, that comprises the vocabulary for discussing political and personal relationships.

Historically, the period embodies the tendency to naturalize generosity in a way that enables power relations to flourish ideologically. Politically, morally, and aesthetically, eighteenth-century culture revolved around the collective misrecognition of the gift and the power of this misrecognition to bolster patriarchal authority and vastly unequal concentrations of wealth. Contemporary discourses of the gift emerged from state, religious, and private attempts to institute public charity, attempts to legitimize traditional systems of authority, and the rise of sentimentality as a marker for moral superiority. An analysis of the gift and generosity in the eighteenth century reveals a cultural tendency to disguise in both the public and private spheres strategies for manipulating power relations.

The number of charitable institutions founded at this time 
cloak the period in a rhetoric of benevolence and social responsibility--over one hundred societies and institutions were created in the eighteenth century to support various charities, schools, hospitals, and almshouses, and to promote specific reforms. Both political and religious documents emphasized giving to the poor as a means to deflect personal and moral responsibility. Clearly, this sudden and widespread interest in charity was driven by a moral instinct: charity offered an escape from personal guilt in this life and an escape from punishment in the afterlife. However, it was also driven by socioeconomic concerns, and the primary motive behind subscribing to a charitable institution was more often than not, in many ways, related to social mediation and authority. Essentially, charity was seen either as strengthening the nation by providing subsistence to the poor and opportunities for labor and production that would ultimately benefit the state, or as an encouragement to corruption and vice.

The Lying-in hospital and the Foundling hospital used appeals to social usefulness to attract subscribers. These charities stressed the number of soldiers, sailors, and laborers who could be saved and added to the national stock. As Donna Andrews states, "That charity that did not stress its practical usefulness, and relied only on disinterested appeals, found it 
much more difficult to attract public aid." 5 For example, the Lock Hospital did not stress the practical benefits of the charity but relied on an appeal to the spirit of Christian charity and thus had far less subscribers. This demonstrates the intersections between giving and self-interest in the emergence of public charities. The successful charities also were able to boast a list of well-known names, famous lords, and important city politicians, so that they attracted smaller, lesser wellknown subscribers who wished to see their names on the same lists. Andrews points out that the number of merchant subscribers was considerably low since they were accustomed to "considering the security and size of the return" before committing themselves or their money to an investment. ${ }^{6}$ Once citizens felt confident that their money would not be lost or spent recklessly, they could indulge fully in contributing to charity. While research supports that most philanthropists did contribute voluntarily, evidence contradicts the solely disinterested motive seemingly informing the subscribers'donations.

The substantial amount of studies that examine charity and benevolence in the eighteenth century fail to interrogate fully

${ }^{5}$ Donna T. Andrews, Philanthropy and Police: London Charity in the Eighteenth century (Princeton: Princeton University Press, 1989), 71.

${ }^{6}$ Ibid, 72 . 
the gift beyond a conception of public duty. ${ }^{7}$ While movements supporting parish relief and foundling hospitals are well documented, the gift as a concept within day to day business or between specific individuals of similar rank and class is glossed over as a natural human inclination to reaffirm social relations through symbolic gestures. These seemingly disinterested exchanges that proliferate in eighteenth-century literature and culture repeatedly are relegated to an affective realm in direct opposition to the self-interestedness of capitalism. In examining a variety of eighteenth-century texts, I draw on the work of contemporary theorists Georges Bataille, Pierre Bourdieu, Jacques Derrida, and Marshall Sahlins, who, in different ways, question the nature and work of the gift. The debates that characterize their works demand a reexamination of eighteenth-century England's commitment to an ethos of generosity. Novels, diaries, poetry, drama, and political tracts point to the prevalence and importance of gift relations in eighteenth-century England, repeatedly demonstrating their implication in wider disparities of power in English society. Typically, however, analyses of instrumental gift relations in industrial or proto-industrial societies, such as England in the

\footnotetext{
${ }^{7}$ For representative studies see Andrews; Beth Fowkes Tobin, Superintending the Poor: Charitable Ladies and Paternal Landlords in British Fiction 1770-1860 (New Haven: Yale University Press, 1993); Roy Porter, "The Gift Relation: Philanthropy and Provincial Hospitals in Eighteenth-century England," in eds. Lindsay Granshaw and Roy Porter, The Hospital in History (London: Routledge, 1989), 149-78; and W. K. Jordan, The Charities of London 1480-1660: The Aspirations and the Achievements of the Urban Society (London: Ruskin House, 1960).
} 
eighteenth century, have focused on charitable donations rather than on economic and social exchange more broadly, suggesting that gift-related behaviors were marginal to the modern market. Because gift economies historically are viewed as alternatives to the self-interest and calculation of capitalism, the gift maintains an idealized status and its obligatory nature is hidden by seemingly reciprocal and equal exchanges. My project, therefore, reads eighteenth-century texts for the ways they represent the socioeconomic work of the gift, social and individual expectations of reciprocity, the motivations for giving, and the relations that are maintained and fractured within gift economies. The social and literary texts of this period present the rise, complication, and confusion of affective relationships in a market-based culture. On both a public and private level, the gift promises to resolve these conflicts. By examining eighteenth-century representations of gift exchange, I demonstrate how the gift in this period entails both symbolic and practical forms of obligation that serve in a capitalist culture to support both a symbolic paternal authority and an unequal distribution of property.

The multiple definitions of the gift in the eighteenth century are summed up by Samuel Johnson's definition. ${ }^{8}$ According to Johnson, a gift could take the form of a "bequest, endowment,

${ }^{8}$ E.L McAdam, Jr.and George Milne, eds., Johnson's Dictionary, (New York: Pantheon Books, 1963). 
or alms given to the poor;" an inheritance; or anything "bestowed without price; an oblation, offering, bribe." ${ }^{9}$ Eighteenth-century texts consistently conflate the terms "gift," "loan," "favor," "duty," and "debt," thus complicating the ostensible simplicity and selflessness of the gift. A number of texts demonstrate that dowries, contracts, and the marriage market continue the tradition of identifying women and the female body as gifts. Bernard Mandeville's essays on charity and Adam Smith's economic writings are among those that demonstrate the extent to which the politics of generosity permeated both social and private life: the period's concern with giving and receiving informs political tracts, utopian narratives, poetry, drama, and the early novel. Moreover, the narrative of the gift takes the form of a variety of voices, from upper-class educated men, to the laboring lower class, to women. While some of this material lies beyond the scope of this dissertation, the widespread use of the language of the gift testifies to the ideological significance of a rhetoric that is often ignored or misread by critics of eighteenth-century literature.

\section{III.}

Although the language and practice of gift exchange seems to belong to the fields of anthropology and sociology, the gift also

\footnotetext{
${ }^{9}$ Ibid, 149.
} 
involves questions of narrative: gifts tell stories about social interaction. The central question I pose in this project is why, in a period in which people and relationships are more and more defined by a capitalist vocabulary, are the same people and relationships just as often, or in some cases even more so, described in terms of disinterested benevolence and mutual exchange? Accompanying that question is the concern that although gifts and capital are seemingly antithetical, eighteenth-century texts typically do not register an anxiety or conflict about the conflation of gifts and capital, even when they seem to mark a transition in the use of such language, as in the Way of the World.

As economists and anthropologists alike make clear, the advent of capitalism did not mean the death of the gift. The archaic and primitive forms of society to which most anthropologists refer when discussing gift economy may seem inconsequential in the twenty-first century. However, the gift's ability to bind social relations remains at work, and perhaps was even stronger in the eighteenth century precisely because of the threat posed by capitalist innovation. In fact, in most eighteenth-century novels that seem to be about money, it is the gift, not the commodity, that receives the most attention and that is crucial in defining self-identity, kinship relations, social obligation, and the socially sanctioned symbolic relations 
of domination. All of the texts I discuss, it can be argued, offer a critique of the charitable spirit of the period, a narrative of obligation that exposes the ramifications attached to so-called disinterested gestures of benevolence.

I would like to explain how my interdisciplinary approach offers a new way to understand the period and the central conflicts that often seemed to dominate non-fictional and literary texts. For literary scholars, most anthropological studies analyze and describe communities with social, political, and economic conceptions of the world, their communities, and their own identities that are dramatically different from early modern European perceptions of experience. For example, Marcel Mauss's ground-breaking analysis of gifts, Essai sur le don, addresses the meaning and function of the gift within a precapitalist Maori culture whose ideological values and assumptions seemingly operate outside of familiar realms of profit, individualism, and economic domination. ${ }^{10}$ Consequently, it is reasonable to ask how such an anthropological approach can be used to examine the radically different culture of eighteenthcentury England; a culture which takes as its basis of personal and social signification principles concerned primarily with property, profit, individualism, and socioeconomic stratification. My answer to this question lies not in arguing

\footnotetext{
${ }^{10}$ Marcel Mauss, The Gift: The Form and Reason for Exchange in Archaic Societies, trans. W.D. Halls, (London: Routledge, 1990).
} 
for similarities between different cultures but in demonstrating that a connection exists between the languages and methodologies of non-European and early modern European cultures. While Mauss's Maori culture may function within a system of gift exchange and reciprocity, that culture still depends on complex economic exchanges based on notions of value and valuation to mediate social and personal experience. In this respect, the languages of gift and obligation are not limited to "primitive" cultures. As I will demonstrate in this project, communities maintain themselves on the belief that relationships with other individuals ensure their own survival. In the eighteenth century, Adam Smith claims that there never can be a "community of thieves and robbers": they would have to agree not to steal from each other in order to maintain a sense of community. ${ }^{11}$ Like other writers of the period, Smith sees morality and exchange as interdependent. In this respect, the language of gift exchange offers a way to reassert the identity of communities based on mutual obligations at a time when such relationships were perceived to be in crisis. In the remainder of this introduction, I examine the assumed disparity between gift economies and market economies that I outlined above, as well as the complex role played by gift exchange in capitalist culture. In discussing the work of Bataille, Bourdieu, Derrida, and Sahlins, I demonstrate the

\footnotetext{
${ }^{11}$ Adam Smith, The Theory of Moral Sentiments, ed. D.D. Raphael and A.L McFie (Oxford: Clarendon Press, 1976).
} 
timeliness and relevance of my argument to current economic theory. These writers represent a variety of theoretical approaches to understanding gift economies, and I critique these theories to emphasize the need for an expanded paradigm that accounts for the internalization of the logic of gift exchange in relationships based on affective exchanges rather than simply material transactions. I argue that although contemporary theory attempts to demystify the gift, ultimately it remains an idealized embodiment of an ethic of generosity. Thus, those who seek to formulate a theory of gift economy as an alternative to capitalism in actuality reinscribe the problem they attempt to solve.

Almost all twentieth-century critiques of gift economy respond either explicitly or implicitly to Mauss. The notion that gift exchange throws into relief the impersonal calculations of capitalism was best articulated by Mauss and has informed a generation of scholars who sought to defend or critique the notion of a system of exchange that did not seek to maximize profit and further self-interest. ${ }^{12}$ Mauss defines gift economy as a series of reciprocal exchanges that invoke an obligation to reciprocity, thereby mediating social relationships that are free

\footnotetext{
${ }^{12}$ For a number of interdisciplinary responses to Mauss see Alan D. Schrift, ed., The Logic of the Gift: Toward an Ethic of Generosity (New York: Routledge, 1997); Mark Osteen, ed., The Question of the Gift: Essays Across Disciplines (New York: Routledge, 2002); Margot Finn, The Character of Credit: Personal Debt in English Culture, 1740-1914 (Cambridge: Cambridge University Press, 2003), 7-11; and Natalie Zemon Davis, The Gift in Sixteenth-Century France (Madison: The University of Wisconsin Press, 2000), 3-10.
} 
from concerns of material gain: "... clans, families, and individuals create bonds through perpetual services and countergifts of all kinds, usually in the form of a free gift...". ${ }^{13}$ In this economy, it is the gift, not the commodity, that accounts for the acquisition and distribution of all wealth: the gift has the capacity to demand a return immediately or the promise of a return in the future, creating an "unceasing circling of both goods and services, returned and to be returned". ${ }^{14}$ This obligation, according to Mauss, functions socially to negotiate competing claims and to settle disputes about authority, rank, and familial status. For example, one could defeat a rival by giving a gift with the knowledge that the rival could not possibly reciprocate; thus, the opponent suffers defeat because he is thereafter always under an obligation he cannot fulfill. Despite the obligatory nature of the gift, however, Mauss perceives gift economy as distinct from the principles of capitalism. He makes clear that gift economy is not dependant on individual production or on profit--neither the giver nor the receiver acquires any material gain: "the object received as gift, the received object in general, engages, links magically, religiously, morally, juridically the giver and the receiver". ${ }^{15}$

\footnotetext{
${ }^{13}$ Marcel Mauss, "Gift, Gift,” trans. Koen Decoster in Schrift, 28.

${ }^{14}$ Ibid, 29.

${ }^{15}$ Ibid, 29.
} 
The gift supposedly informs and structures non-material values only--alliances, diplomacy, friendship, kinship, sacrifice, and marriage.

Mauss's essay continues to provoke a dialogue on giftexchange for two fundamental reasons. First, his basic assertion locates the gift in primitive societies as a form of exchange that privileges social relations between people rather than material relations between objects. Gifts are exchanged with the expectation of an immediate reciprocal equivalent or the understanding that an equivalent counter-gift will be given at a later date. In this sense, the gift entails obvious obligation-the initial gift must be returned. Therefore, the gift in primitive societies always entails either implicitly or explicitly a double assumption--that one will receive and hence one will give. The second argument that gives rise to debate is Mauss's claim that the socially mediating work of the gift resides in the "hau" of the gift, a mystical social quality that he defines as "the total social fact."16 For Mauss, the hau is the property that compels the gift to circulate, to be given and returned: "it is the spirit of the thing to come back again and again."17 By assigning this mystical quality to the gift, Mauss sees gifts acting on society to reinforce personal relationships

\footnotetext{
${ }^{16}$ Ibid.

${ }^{17}$ Ibid.
} 
between the subjects transacting, rather than members of society using gifts to establish a relationship and to negotiate the comparative values of the objects exchanged. Mauss's theory is open to critique, therefore, because the notion of the hau fails to explain why we give in the first place and thus his explanation replaces interested gestures with the mystical quality of the gift.

Mauss's claim has encouraged at least some of his readers to perceive gift economies as idealized forms of disinterested exchange based on an ethic of generosity rather than profit. Anthropologist C.A. Gregory draws from Mauss' study a distinction between the work of commodities and the work of gifts: "Commodity exchange establishes objective quantitative relationships between the objects transacted, while gift exchange establishes personal qualitative relationships between the subjects transacting."18 In gift economies, objects take on a non-alienated form--the personification process dominates and things and people assume a social function. As a result, gift economy establishes personal, qualitative relationships between subjects. In contrast, according to Gregory, in capitalist economics things and people take on the form of objects, thereby objectifying the relationship between people and establishing a relationship between things. Rather than reinscribing the opposition between

\footnotetext{
${ }^{18}$ C.A. Gregory, Gifts and Commodities (London: Academic Press, 1982), 41.
} 
gift and commodity that Gregory describes, a number of critics within the social sciences and humanities have attempted to theorize a logic of gift exchange applicable to modern society. Questions of the gift within contemporary discourse can be traced to four distinct responses to Mauss, exemplified by the work of Georges Bataille, Pierre Bourdieu, Jacques Derrida, and Marshall Sahlins. I begin with Bataille who most closely frames a paradigm influenced by Mauss. Bataille proposes in The Accursed Share that the basic movement of economy is predicated on loss--a general economy of surplus, sacrifice, and gifts. ${ }^{19}$ The modern capitalist economy, which he terms a restricted economy, in turn stultifies the natural process of expenditure by restricting economy to accumulation and "squandering without reciprocation." ${ }^{20}$ Bataille is very much influenced by Mauss in his assertion that a return to "the basic movement that restores wealth to its function, to gift-giving" will alleviate disparities of wealth by forcing the expenditure of excess rather than reinforcing the limits of accumulation. ${ }^{21}$ Bataille's theory, idealized in its attempt to provide an alternative to modern poverty, socioeconomic inequality, and war, reifies Mauss's

\footnotetext{
${ }^{19}$ Georges Bataille, The Accursed Share: An Essay on General Economy, Vol. 1 Consumption, trans. Robert Hurley, (New York: Zone Books, 1988) 25.

${ }^{20}$ Ibid, 20.

${ }^{21}$ Ibid, 38.
} 
notion that gift economies take place outside of interest, and he fails to recognize or critique the logic of value that incites competing desires for goods--whether exchanged reciprocally as excess or in market negotiations.

Bourdieu comes closer to collapsing the dichotomy between gift economies and capitalism by describing gift exchange as the necessary and collective misrecognition that informs social practice. Bourdieu examines the gift as a mode of social domination and argues in The Logic Practice that the gift works as a "veil of enchanted relations" to cover up violence. ${ }^{22} \mathrm{He}$ identifies gift exchange as a practice of irreversible actions constructed in time: a sustained, collective misrecognition of the "objective" truth:

This generative model ... reduces exchange to a series of successive choices performed on the basis of a small number of principles with the aid of a simple combinatory formula, and which makes it possible to give a very economical account of an infinity of particular cases of exchanges phenomenally as different as exchanges of gifts, words, or challenges... [which] reproduces, in its own order, the functioning of habitus....23

\footnotetext{
${ }^{22}$ Pierre Bourdieu, The Logic of Practice, trans. Richard Nice (Cambridge: Polity Press, 1990), 217.

${ }^{23}$ Ibid, 100 .
} 
The logic of practice "proceeds through a series of irreversible choices, made under pressure and often involving heavy stakes...in response to other choices obeying the same logic." ${ }^{24}$ For Bourdieu, then, relinquishing the idea of gift exchange as a primitive, pre-capitalist practice allows us to examine it as a phenomenon of exchange itself, with strict laws and inscribed models of behavior that inform both pre-modern and modern societies. His "economical account" of the dynamics governing "an infinity of particular cases of exchanges" implicates both givers and receivers, who, once engaged in the process, either become trapped in the laws of the practice or risk disrupting social constructs and symbolic notions of honor, authority, and power. ${ }^{25}$ Gifts, therefore, act as symbolic capital in the sense that they are capital misrecognized. Gift exchange is the conversion of economic capital into symbolic capital which produces relations of dependence that have an economic basis but which are disguised:

The motor of the whole dialect of challenge and riposte, gift and counter-gift, is not an abstract axiomatics but the sense of honour, a disposition inculcated by all early education and constantly demanded and reinforced by the group, and inscribed in

\footnotetext{
${ }^{24} \mathrm{Ibid}, 103$.

${ }^{25}$ Ibid, 100.
} 
the postures and gestures of the body... as in the automatisms of language and thought... ${ }^{26}$

In this respect, the gift must be misrecognized because it is a form of symbolic violence, of enacting a relationship of dominance and dependence, as Mirabell seems to recognize; according to Bourdieu, "..the strategy of the gift will be destroyed if its true nature is revealed."27 Bourdieu's critique ultimately implicates the gift not just in a general sense of obligation, but to specific systems of domination.

In a different but related vein, Derrida argues that the gift itself is impossible; that the giving of a gift is a paradoxical instance in which the gift is negated by its very recognition as gift. Derrida argues that the "possibility of the impossibility of the gift" is inherent in all acts of gift exchange. ${ }^{28}$ The staging of gift-giving eludes the possible since the moment the gift presents itself as gift it simultaneously is annulled:

For there to be gift, it is necessary that the gift not even appear, that it not be perceived or received as gift...as soon as it appears as gift or as soon as it signifies itself as gift, there is no longer any 'logic

\footnotetext{
${ }^{26} \mathrm{Ibid}, 103$.
}

${ }^{27}$ Ibid, 126.

${ }^{28}$ Jacques Derrida, Given Time. 1. Counterfeit Money, trans. Peggy Kamuf (Chicago: University of Chicago Press, 1992), 7. 
of the gift'. ${ }^{29}$

The gift implicates both the subject and the recipient irrevocably in networks of debt, obligation, and self-interest. It is the conditions that define the gift--giving and receiving in return--that "produce the annulment, the annihilation, the destruction of the gift." ${ }^{30}$ Because it is necessary that the recipient not give back, it also is imperative that at the same time he or she not acknowledge the gift as such; recognition of the gift as gift implies a restitution in that it demands in exchange a "symbolic equivalent;" it "perceives the gift...the intentional meaning of the gift... [and] this simple identification of the gift seems to destroy it." ${ }^{31}$ It is the impossibility that interrupts exchange and makes the gift economic, even if there is no gift because the gift "gives back only to the self." 32

Derrida defines the beginning of this (un)economy in the act of exchange, the precise moment when the gift is (mis) recognized by both parties as gift. It is at this moment that economy interrupts the exchange and the gift no longer exists. Recognition of the gift as gift implies that there must be a

\footnotetext{
${ }^{29}$ Ibid, 13.

${ }^{30}$ Ibid, 12.

${ }^{31}$ Ibid, 13-14.

${ }^{32}$ Ibid, 16.
} 
return even if that return lies in a symbolic equivalent. Once the giver and receiver perceive the meaning of the gift--that something has been given that entails labor, expense, or sacrifice on the part of the giver, and that there is intention behind the giving of the gift--then the gift is destroyed. It is the simple identification of the gift that destroys it. What Bourdieu identifies as a necessary process of misrecognition--the gift is possible in the sense that it goes unrecognized for what it truly entails--Derrida deconstructs as impossible. For Bourdieu, the gift never ceases to operate within a system and a logic of economy, but, for Derrida, the gift never ceases to be impossible--it signifies an irrevocable interruption of the logic of idealized reciprocity and exchange.

Sahlins reinforces both Bourdieu's and Derrida's arguments when he critiques the "spirit of the gift."33 Sahlins calls into question the very structure of the exchange itself--the physical act of exchange he sees as annulling the work of the gift. He argues that Mauss's paradigm--that A gives to B, B gives to C, and $\mathrm{C}$ gives back to A--inevitably creates advantage and undue loss:

The introduction of a third party could only unduly complicate and obscure the point.... But if [the point] is rather that one man's gift should not be another

\footnotetext{
${ }^{33}$ Marshall Sahlins, "The Spirit of the Gift" in Shrift, 70-99.
} 
man's capital, and therefore the fruits of a gift ought to be passed back to the original holder, then the introduction of a third party is necessary. It is necessary precisely to show a turnover; the gift has had issue; the recipient has used it to his advantage. ${ }^{34}$

Sahlins' use of the word advantage exposes the innate interest involved in Mauss's theory of gift exchange. More importantly, he points out that in the Maori culture specifically, return gifts are larger and more excessive than the principle of equivalentreturn demands. Sahlins concludes that the exchange turns "upon the exchange between the second and third party" and that what Mauss calls the hau in Maori culture could be better translated "as profit." 35 The gift does not cement a mystical or affective bond among members of a community, but implicates them in complex networks of exchange and re-valuation.

My dissertation explores the consequences of these theories--that the gift is misrecognized, impossible, and defined not by a mystical hau but by profit--by identifying the gift as a means to mask interested commodity exchange. My response to Mauss and to the critics above involves an examination of value, and I would argue that the issue in all of these theoretical arguments,

\footnotetext{
${ }^{34}$ Ibid, 79 .

${ }^{35}$ Ibid, 79 .
} 
but which none articulate, is one of value. Inevitably, the gift is implicated in the economic--even as it is misrecognized or impossible--because it is value. The mystical hau of the gift is not mystical at all because any notion of reciprocity or generosity relies ultimately on an ability to recognize, attribute, or confer value on objects that are given or received. Because the gift has value it incites an expectation of return, a practical, realistic, and necessary expectation that when something is given it has a value that will obligate a return of an equal or greater value. In this sense, I argue throughout this dissertation that the gift is a commodity in disguise.

Marx defines the commodity as an object outside of ourselves that by its very properties satisfies human wants--either a physical want or a want of fancy. ${ }^{36}$ The commodity either has a use-value--a utility--or an exchange value--a proportion in which its value in use can be exchanged for another value in use. Although gift economies appear to function on a social level to establish inter-personal relations, the given object is what retains the power to invoke those relations. Therefore, it must have or be able to acquire the kind of arbitrary exchange value that Marx attributes to commodities.

In order for the gift to meet our expectations of generosity

\footnotetext{
${ }^{36}$ Karl Marx, The Critique of Capitalism, in Robert E. Tucker, ed. The Marx-Engels Reader, $2^{\text {nd }}$ ed. (New York: W.W. Norton \& Company Inc, 1978), 201-465.
} 
and benevolence, the gift must have value. If the gift does not have value, if the recipient does not find in the gift a use value or an exchange value, the gesture of the gift fails. Therefore, I argue that capitalist principles inevitably are at the root of the logic of the gift because the gift depends on a system of exchange that naturally perceives a value in the gifts exchanged. This perception results in gift economies being inherently dialectical: every act of gift-giving is precipitated by a recognition of value within a commodity that can then function as a gift; this recognition invests the "gift" with the power to demand a return. Simultaneously, the value embedded in a counter-gift--even before the first recipient recognizes the gift as gift--precipitates every act of gift exchange. Rather than enacting a reciprocal and balanced exchange, gift giving provokes an ongoing negotiation of values. Unlike a commodity, which is assessed and valued according to an absolute standard--Marx's general equivalent--gifts seem to negotiate their relative values with and against each other. The fiction of gift exchange is that it somehow suspends or erases the dependence of valuation on a general equivalent.

Thus, I would argue, Derrida comes to the impossible too late. His identification of the gift as impossible in exchange fails to recognize the value the commodity holds prior to its introduction into circuits of benevolence, debt, or obligation 
that allows it to function as gift and embody a sense of sacrifice, affection, and disinterest. Bataille, too, overlooks the concept of value. The expenditure he promotes must always already derive from an awareness, even if an unconscious one, of a return that embodies value--of an idealized reciprocity that must be violated in excess expenditure and loss. The fascination with loss resides in the fascination with gain--the belief in a gained value is only appreciated in the context of what is lost-a substitution is always expected or at least hoped for. While Bourdieu and Sahlins come closest to implicating the gift in the logic of exchange that mutually informs capitalism and theories of the gift, both hold open the possibility that either the logic of practice or the spirit of the gift can continue to suture over precisely the problems with the gift--its misrecognized violence and inevitable demand for a return and profit.

In response to these critics, I argue for an expanded paradigm that identifies gifts in all stages of gift exchange as commodities, and thus inherently economic. In this dissertation, I demonstrate that theoretically and historically there is never an instance of equal gift exchange--when what one gives is equivalent to what one receives. Rather, gift economies act as a stabilizing mechanism that underwrite a collective economic fantasy of equitable exchange. This fantasy fosters the misrecognition Bourdieu identifies of the values of benevolence, 
generosity, and disinterestedness associated with reciprocity. Eighteenth-century representations are crucial for this study because they offer both an historical and theoretical entrance into reading acts of disinterested exchange and obligation. In the literary and cultural texts that I study, gifts assume a fundamental importance as markers for a range of values-reciprocity, benevolence, generosity, friendship, diplomacy, love, and sacrifice--that either implicitly or explicitly are seen to stand outside of capitalist calculation. By examining eighteenth-century representations of gift economies, I demonstrate that gift exchange entails both symbolic and practical forms of obligation that negate the possibility of disinterested economic exchange: a gift is never congruent with itself and serves in a capitalist culture to support in both the political and domestic spheres a symbolic paternal authority. My examination of the narrative of the gift is a study of the account of the gift in the eighteenth century, of why early modern capitalists gave and expected to receive within a system of exchange innately predicated on loss.

\section{IV.}

In different ways in the chapters that follow, I argue that the sociocultural circumstances of the eighteenth century reveal a complex relationship between giving and receiving that has 
ideological consequences for conceptions of gender, family, and socioeconomic identity. In order truly to appreciate the ramifications of gift exchange in early modern capitalist culture, the motivations for giving require examinations beyond the abstract notion of social charity. Therefore, I discuss representations of exchanges that clearly elude or resist moral prerogatives. Rather than focusing solely on the poor and the philanthropic institutions constructed to aid and monitor the lower classes, my study examines gifts given within relatively equal socioeconomic classes and the power relations inherent in those exchanges.

Chapters two through five offer close examinations of this collective misrecognition of the gift and the modes of domination the gift supported in the eighteenth century. The account of the gift presents itself as "impossible" and "misrecognized" in both fictional and non-fictional texts. Chapter two, titled "Prisoners in Silken Bonds': Obligation, Diplomacy, and Trade in English Voyages to Japan and China," focuses on public representations of gift exchange within the conceptions of international economy evident in diplomatic encounters at the beginning of the seventeenth century and at the end of the eighteenth century. I begin with this analysis of public transactions conceived of in terms of the gift to trace the development of ideas of a collective and disinterested economy as 
an alternative to capitalist practice. This chapter precedes my discussion of private institutions and novels because I argue that the misrecognition of the gift begins in the public sphere.

I assert in this chapter that the inevitable loss that accompanies the gift simultaneously situates it as a domestic and international signifier of civility that mediates relations of power and difference. Thus, gifts presented to Japanese and Chinese officials as incentives for expanding English trade become the means to elicit desire, create illusions of superiority, and to "give" generously what one cannot sell. My reading of historical documents examines catalogues of gifts exchanged between English and Far East merchants to show that the gift, while seemingly antithetical to basic capitalist principles, serves to define diplomatic and economic relationships that the English unsuccessfully try to manipulate for material gain.

Chapter three "'Comply and Live, Deny and Starve': Asymmetrical Exchange in Defoe's Roxana" argues that the account of the gift--of why we give and expect to receive in return--in the eighteenth century produces a specific narrative structure, one that is problematized by the very nature of the complex subject it seeks to represent. Because gift exchange fosters unending obligatory relationships, narrative attempts to represent this process necessarily reflect the inability of the 
exchange to produce a coherent conclusion. While this structure permeates both cultural documents and literary representations, I draw mainly on Roxana as an exemplary text. Roxana, along with other texts I examine in subsequent chapters, demonstrates the impossibility of rendering satisfactorily an account of the gift. First, the narrative structure of Roxana is complicated by the fact that the plot revolves around the on-going exchange of gifts and the heroine's inability to engage in equivalent exchanges. The unending obligation Roxana experiences forces the novel to conclude abruptly because Defoe cannot articulate an end to the cycle of exchanges that drives his narrative.

Moreover, Roxana's self-interrogation, in which she questions her continuing career as a mistress despite having achieved financial independence, demonstrates precisely the fiction of the gift. Although Roxana has economic security, the novel's inability to resolve her obligation as a receiver of gifts formally and ideologically demonstrates that the initial gift that led to this security has never been and can never be repaid. The reciprocity she offers by giving over her body to the landlord is not a disinterested return but an obligation. Moreover, it is an obligation that continues to accrue interest, thereby preventing Roxana from escaping the first debt, and the narrative from representing an equal and completed gift exchange. While financially Roxana can reciprocate, morally she always is 
indebted. Thus, the account of the gift reveals its double bind: the gift appears as an idealized, non-commodified act of agency and generosity that simultaneously enables a coercive, unending obligation that begets further obligation--an obligation from which one cannot be released, even within an imaginative rendering .

Chapter four, "Property, Legitimacy, and Socioeconomic Debt: The Misrecognized Gift in Tom Jones," examines issues of upperclass authority, ownership, and benevolence in Henry Fieling's Tom Jones. I argue that gift giving--misrecognized as a generous and disinterested act--sutures over relations of authority and domination that underlie the socioeconomic order depicted in the novel. To understand the dynamics of asymmetrical exchange in Tom Jones, I draw on the work of Bourdieu and Slavoj Zizek. In drawing on both of their concepts of misrecognition, I identify a double-misrecognition as the actual practice that enables both capitalist and gift exchange to be possible. In contrast to Zizek who describes misrecognition as the overlooking of the "universal, socio-synthetic dimensions" of an act, and Bourdieu who identifies misrecognition as the overlooking of "imposed relations of kinship, neighborhood, or work," I argue that misrecognition inheres in the socioeconomic dimension of exchange--whether capitalist, gift, or barter. The exchange must be misrecognized as performative: each act must represent an 
idealized social relationship that can be rendered in terms of mutual advantages and reciprocal obligations.

Squire Allworthy's unending generosity is misrecognized by his recipients in order to deny (to themselves as well as to others) the obligation they have to his authority, both before and after they receive his gifts. In analyzing key episodes in the novel, I argue that Allworthy exchanges his material property for the coerced return of an unending moral and social obligation. What his recipients interpret as disinterested gifts that they want to honor in return for his generosity are, in actuality, contracts that bind them to Allworthy's moral standard. The recipients of Allworthy's "gifts," including Tom, misrecognize asymmetrical relations of obligation because they misrecognize their socioeconomic debts to Allworthy and the order he embodies. Throughout Tom Jones the ideology of domination must be misrecognized as the rationale for the affective and mutual bonds of social cohesion.

Chapter five, titled "'Her Gift Was Compelled': Gender and the Failure of the Gift in Cecilia," extends my discussion of affective relations by providing a contrast to the gender politics of courtship seen in Roxana and Tom Jones. This chapter moves to the seemingly most private of relations, the family. I demonstrate how the public and collective fantasy of equal exchange becomes a way to manipulate kinship and gender roles to 
conceal power relations and perpetuate in the private sphere a public ideal of authority. I examine Cecilia for the ways in which the novel inscribes the gift as a feminized and domesticated practice in order to bolster a repressive and patrilineal economic system. I interrogates the values of the gift that align generosity with the feminine, the power relations involved in giving and receiving, and questions of how notions of feminine agency are complicated by acts of giving .

My analysis looks at the heroine's relationship to Harrel, Albany, her guardians, and the Delville family to examine the many ways in which Cecilia is imposed upon through the notion of the gift. As a woman who accrues both debts and obligations, she occupies the role of agent and object--someone with money to give and control, and yet someone who, as woman, is controlled and exchanged through the laws of primogeniture and marriage. Cecilia depicts women and children as owing paternal obligations that are necessary to regulate and reinforce an ideology of paternal authority and patrilineal succession. Furthermore, the novel dramatizes challenges to the assumed division between the public and private spheres by relegating all forms of exchange within the private as "gifts" that nonetheless have material consequences for Burney's heroine. My reading of Cecilia ties in to both the theoretical and historical concerns with which I began 


\section{$\boldsymbol{V}$}

Emerging capitalist principles in the eighteenth century blur the boundary between commodity and "gift," calling into question historical and contemporary possibilities of ethical gift exchange. Critics such as James Thompson have argued that the period reveals an anxiety towards stabilizing notions of value and language that economic changes called into question: "The historical conditions of money and its transformation into capital in conjunction with the advent of various and disturbing new forms of paper money, provoked a semiological crisis over the concept of value." ${ }^{37}$ Thompson describes the emergence of eighteenth-century economic instability as a consequence of the severe debasement of English coinage following a half-century of "shifting regimes and neglect, from the civil war through the interregnum and the Restoration...." ${ }^{38}$

...for it is the period which witnesses the end of primitive accumulation and enclosure and that transition to agrarian capitalism, the development of the first stage of market capitalism, and the extension of commodity relations into all areas of social life. ${ }^{39}$

\footnotetext{
${ }^{37}$ James Thompson, Models of Value: Eighteenth-century Political Economy and the Novel(Durham: Duke University Press: 1996), 17.

${ }^{38}$ Ibid, 15 .

${ }^{39}$ Ibid, 33.
} 
Paper credit and speculative finance also contributed to shifts in value. The change in conceptions of the nature of property from a material, immovable, and stable form such as land to an immaterial and fluid one threatened traditional socioeconomic order. This was perpetuated further through the development of public credit, banking facilities, and joint stock companies. ${ }^{40}$ As Catherine Ingrassia points out, "With a change in the nature of value systems, property became increasingly unreal. The new financial instruments of Exchange Alley were largely immaterial forms of property that could be realized only imaginatively." 41 Like such phenomena as speculative investment and credit, the gift relies on a liminal moment of indeterminancy. Therefore, although similarly ambiguous, the gift becomes a cultural fantasy invoked as a means to reassert stability beyond the vagaries of the market. Because these emerging economic issues could not readily be stabilized in the eighteenth century, the gift functions as a way to put into abeyance conflicts of value and to draw to attention the practice of exchange itself. The seeming disinterestedness of gift exchange allows it to perform acts of ideological recuperation by masking the realities of capitalist exploitation and self-interest. Significantly, a society that

\footnotetext{
${ }^{40}$ For representative studies on economic innovation, banking practices, and exchange in the Eighteenth century see Thompson, Models of Value; Catherine Ingrassia, Authorship, Commerce, and Gender in Early Eighteenth-century England: A Culture of Paper Credit (Cambridge: Cambridge University Press, 1998); and Liz Bellamy, Commerce, Morality, and the Eighteenth-century Novel (Cambridge: Cambridge University Press, 1998).

${ }^{41}$ Ingrassia, 5.
} 
relied on overt charity to reconcile political and religious responsibility simultaneously and collectively adopted a misrecognition of other forms of giving to perpetuate a symbolic mode of domination.

Although eighteenth-century economic theory points to the coin and the banknote as the confusing and unstable signifiers of capitalism, the gift in eighteenth-century England most often took the form of money or of a commodity. Therefore, in an analysis of a culture where money comes to represent the confusion between intrinsic and extrinsic value in both monetary terms and in terms of social identity, the gifts of money and commodities which hold the potential either to stabilize or overturn the tenuous definition of value become even more appealing to the theorist and critic than the theory of money itself. Thompson argues that capitalism emerges as a model for regulating the self. The language of capital, he maintains, becomes analogous to the language of the self and social relations. In extending and supplementing his argument, this dissertation suggests that as capitalism emerges so does the seeming opposition to capitalism, and that the gift, too, in its misrecognition, becomes, in the eighteenth century, a model for the self. 


\section{Chapter TWO}

\section{"Prisoners in Silken Bonds": Obligation, Trade, and Diplomacy in English Voyages to Japan and China}

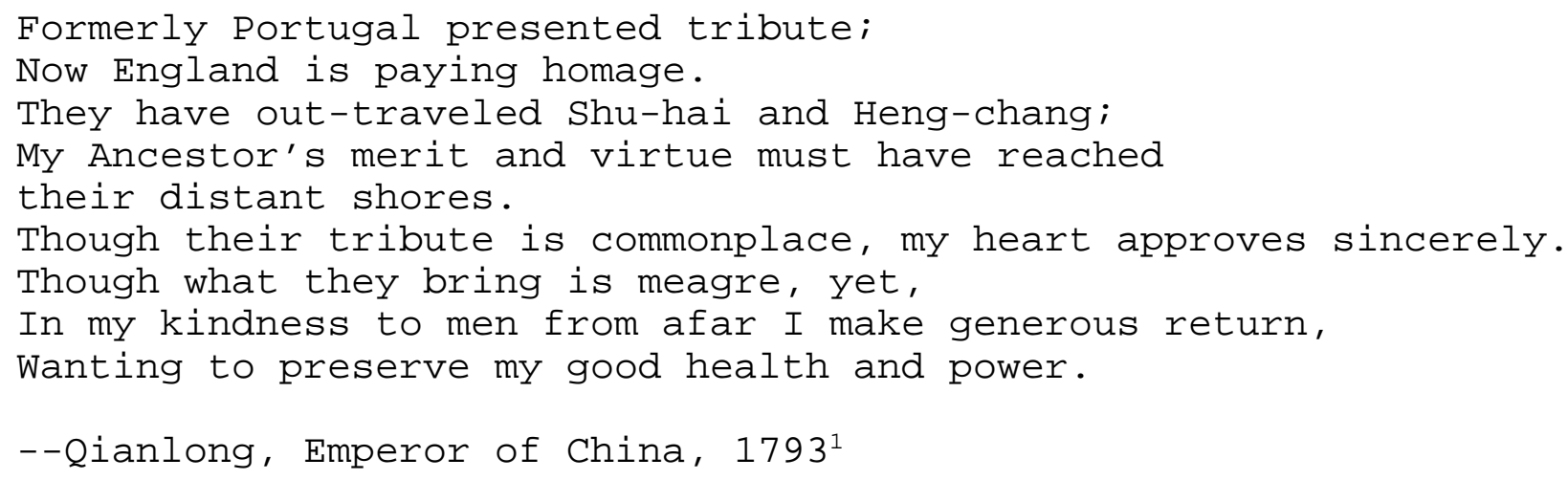

\section{$I$.}

The poem above, composed by the Chinese Emperor Qianlong to mark the arrival of Lord George Macartney's embassy in Jehol, China, in 1793, invokes a cross-cultural language of gift exchange, reciprocity, and obligation that informed early modern conceptions of international trade and diplomacy. In the mind of the Emperor and in accordance with a long-standing Chinese cultural self-perception, Macartney's appearance at the Imperial Court, his letter from King George III, and the presents he offers register solely as a tributary offering: the gesture of a 1963), $x$.

\footnotetext{
${ }^{1}$ Lord George Macartney, An Embassy to China, ed. J.L. Cranmer-Byng, (Hamden: Archon Books,
} 
barbarian race to acknowledge and to celebrate China's cultural and religious superiority, and to reinforce the Emperor's supreme virtue. Acknowledging precedent for the honor by invoking Portugal's diplomatic standing as a country that has recognized China's greatness and, therefore, gained the privilege of a trading monopoly in Macao, the Emperor interprets the gifts Macartney brings as a sign of deference to a more powerful and advanced society, one whose merit has extended across the globe. Although the gifts the English bring are viewed as "commonplace," and their commercial value in China "meagre," the Emperor shows respect for the distance the embassy traveled and the tributary offering they transported by making what he considers to be an adequate and "generous return"--namely, his kindness. The Emperor's return of kindness, however benevolent and commensurate it appeared from the Chinese point of view, was perceived by the English as an unequal exchange. Their mission--although they understood that China expected a tribute--was to gain in exchange for their innovative and scientifically advanced gifts a diplomatic trading treaty, commercial ports of trade, and compensation for the grievances of the English merchants. However, the Emperor's language implies that his reciprocity derives solely from a benevolent nature, that he gives in return out of respect, not out of obligation. This distinction slyly displaces momentarily the obligation implicit in any gift 
exchange; in other words, Qianlong does not consider himself indebted to the English or required to make a return. Yet, almost simultaneously, the Emperor does acknowledge an obligation, though not to the English. The Emperor's return gift of hospitality is a submission required of him to a divine authority and to ancestral good fortune, both of which have endowed him with the power to give generously. Furthermore, the Emperor anticipates a return for this obedience to authority as well--he gives adequately to the English to preserve the kingdom's honor and so that he may maintain in return "good health and power." Thus, the notion of the gift as an ostensibly disinterested gesture of civility--of an equal exchange between reciprocally respectful nations--becomes problematic: what the English viewed as civility the Chinese interpreted as a ritual of subjection. Qianlong articulates an Asian perception of the complex intersections among trade negotiations, diplomatic gift exchanges, and cultural authority that ironically informed an English ideology of early modern trade as well. The poem invokes notions of honor, reciprocity, and return, a vocabulary, that in seventeenth- and eighteenth-century mercantile and political narratives, repeatedly qualifies profit-based concerns in the relationships the English sought to establish and extend in the Far East. The English gave to the Emperor in expectation of an equal return, an expectation that they articulated only in order 
to obligate the Emperor to grant their requests. Although the English accepted his gifts and other amenities while in China, their expectation of an equal and satisfactory return necessitated an on-going diplomatic exchange that deferred the commercial negotiations they sought literally at their own expense. In this sense, the language of the gift, despite its ostensibly disinterested nature, created between the English and their would-be trading partners unequal relations of obligation and domination.

This chapter examines the intersections between seventeenthand eighteenth-century conceptions of the gift in commercial trade and diplomatic relations to argue that the Eurocentric ideology of mutually beneficial trade was promoted by a fantasy of equal exchange that sutured over relations of subjection and domination. Rather than establishing relations of equality through disinterested and benevolent gifts, diplomatic gifts are used--by both Europeans and Asian nations--to mask the aggressive and acquisitive self-interest that characterizes relations of power and domination. I draw on English travel and diplomatic narratives and their representations of gift exchange, as well as East Asian conceptions of tribute, to examine how both East and West utilized the language of the gift to negotiate competing conceptions of cultural authority. Specifically, I examine the journal of John Saris, the captain of the first East India 
Company ship to land in Japan in 1613, and the published accounts by Lord Macartney, leader of the first English Embassy to China in 1793 .

English tracts on trade during this period, such as Nicholas Barbon's A Discourse of Trade, John Evelyn's Navigation and Commerce: Their Original and Progress, and Adam Smith's The Wealth of Nations, emphasize that the success of public trading practices was grounded in the development of personal and disinterested relations mediated by a general gift economy. ${ }^{2}$ The gift in these narratives served two functions. First, for philosophers of trade, the rhetoric of mutual exchange displaced motives of self-interest and profit. The language of the gift drew attention to the ostensible benevolence and tolerance of both the English and Far East peoples, positing each nation as rich enough to market in a general economy based on surplus. Second, for the English the mutuality and benefit sutured over the processes of consumption and production that threatened to feminize the English and either strip the Far East of natural resources so as to preserve those at home, or to displace anxieties about the fact that the English literally during the course of the eighteenth century were becoming addicted to tea,

${ }^{2}$ Nicholas Barbon, A Discourse of Trade, (London, 1690); John Evelyn, Navigation and Commerce, Their Original and Progress, (London, 1674); Adam Smith, The Wealth of Nations, Books I-III, ed. Andrew Skinner, Rev. ed, (New York: Penguin, 1999). 
porcelain, and later, opium. The language of the gift transposed to diplomacy reflects two dialectics. First, each exchange is an end in itself that establishes what are supposed to be "timeless relations": for the English, a civilized and mutually beneficial trade, for the Chinese, in 1793, the tributary status of another barbarian country. Yet, second, the exchange also promoted an unending obligation so that, in theory, gifts must be exchanged each and every time emissaries meet, and these occasions too are open to radically different interpretations: for the English, ongoing negotiations to transform financial and symbolic burdens and obligations to mutual trade; for the Japanese and Chinese courts, a re-enactment of subjection.

In the accounts of Saris and Macartney, the detailed descriptions of gifts offered to the Shogun and the Qianlong Emperor seemingly promote an ideal of mutually beneficial trade. Journals such as Saris' are monopolized by discussions of giftexchange, which stands out as the primary form of diplomacy involved in foreign relations. In fact, the detailing of gifts often overshadows the commercial aspects of such enterprises, including account records, the progress of the factory, and the sale of commodities--those aspects of these missions vital to East India Company officials for profit-based ventures. The prominence of gifts in Saris' journal demonstrates that the role of gift exchange held far greater implications than those 
associated solely with social customs or diplomatic formalities. The gifts inscribed the English and the Japanese shogun in a network of social debt and reciprocity, one that was much more tenuous and complex than the English may have realized, and which paradoxically held far more severe consequences than the actual business relationships they sought to forge.

This complexity is due to the cross-cultural awareness of the obligatory nature of the gift and its role in mediating a market economy. Both European merchants and the courts of the Far East recognized the inherent social aspects of commerce: in order to cultivate a productive business relationship, European merchants and court officials had first to cultivate a personal and political relationship of mutual trust that supposedly would mirror and enact an idealized relationship between an English merchant and his East Asian counterpart. The inordinate amount of time spent by merchants and emissaries documenting gift exchanges, including the types of gifts exchanged, the places and times, and the social transactions occurring simultaneously with the gift-exchange, demonstrates both how gifts permeate commercial activity and how dependent self-interested capitalism is on the social dynamics of the gift. My reading of these texts, then, explores the ways in which diplomatic customs complicated attempts at trade and trapped the participants in on-going 


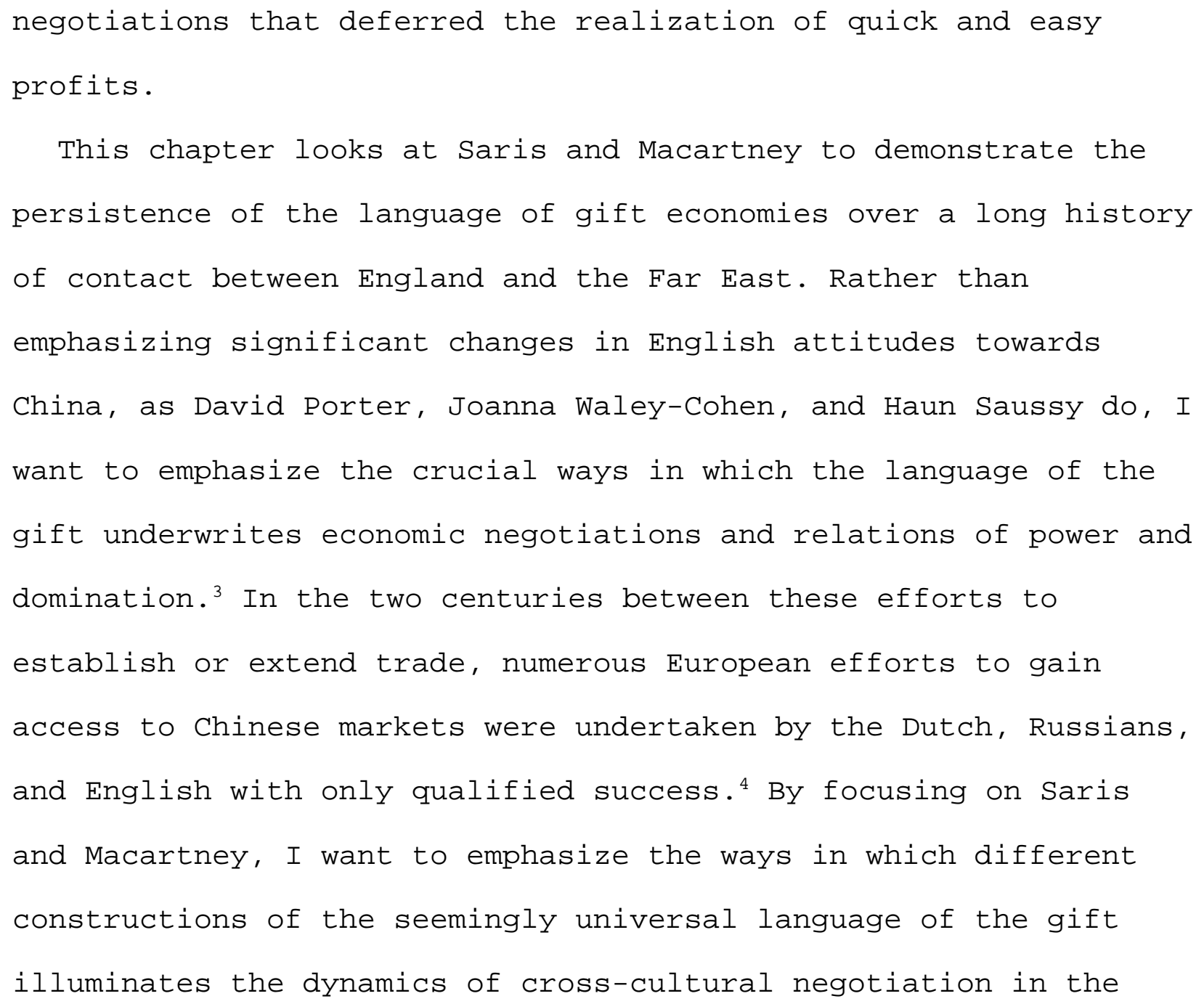

${ }^{3}$ David Porter, Ideographia: The Chinese Cipher in Early Modern Europe, (Stanford: Stanford University Press, 2001); Haun Saussy, Great Walls of Discourse and Other Adventures in Cultural China, (Cambridge: Harvard University Press, 2001); Joanna Waley-Cohen, The Sextants of Beijing: Global Currents in Chinese History, (New York: Norton, 1999).

${ }^{4}$ The first hand accounts of these efforts include Jan Nieuhoff, An Embassy from the East-India Company of the United Provinces, to the Grand Tartar Cham Emperor of China; Delivered by their Excellencies Peter de Goyer, and Jacob De Keyzer, At his Imperial City of China, trans. John Ogilby, (London, 1669); Evret Ides Ysbrants, Three Years Travels from Moscow Over-Land to China, (London, 1706); Alexander Hamilton, A New Account of the East Indies: 2 vols, (Edinburgh, 1727). For discussions of the significance of these ventures see John E. Willis Jr., Pepper, Guns, and Parleys: The Dutch East India Company and China, 1662-1681, (Cambridge: Harvard University Press, 1974); John E. Willis Jr., Embassies and Illusions: Dutch and Portuguese Envoys to K'ang-hsi, 1667-1687, (Cambridge: Council on East Asian Studies, Harvard University, 1984); and Derek Massarella, A World Elsewhere: Europe's Encounter with Japan in the Sixteenth and Seventeenth Centuries, (New Haven: Yale University Press, 1990). 
early modern world. Furthermore, I want to establish how some of the travel narratives and diplomatic encounters that are described by English merchants in the Far East demonstrate the inextricable link between gifts, economy, and capital in international negotiations during the early modern era. These important cultural texts reveal the ideological assumptions and values that link gifts and exchange and suggest why the gift figures as a central narrative in fictional texts throughout the eighteenth century. Although notions of the gift are most often relegated to the category of an uneconomic, disinterested exchange, this chapter will demonstrate how the logic of the gift underwrites both English and Asian conceptions of commercial exchange. Most analyses of international relations between England and Asia have focused on mercantile competition, and the colonial and/or post-colonial implications of England's contact with the Far East, suggesting that the gift-related behaviors documented in these interactions were marginal to the modern market. ${ }^{5}$ Deconstructing the gift in early modern trade demystifies gift exchange as a selfless and disinterested "alternative" to capitalism, and demonstrates the ways in which capitalist obligation was grounded in social relations.

\footnotetext{
${ }^{5}$ See particularly Andre Gunder Frank, Reorient: Global Economy in the Asian Age, (Berkeley and Los Angeles: University of California Press, 1997); Kenneth Pomeranz, Europe, China, and the Making of the Modern World Economy, (Princeton: Princeton University Press, 2000); and K.-N Chaudhuri, Asia before Europe: Economy and Civilization of the Indian Ocean from the Rise of Islam to 1750, (Cambridge: Cambridge University Press, 1990).
} 
Such an analysis reveals the means by which diplomacy ostensibly based on trust and equality was manipulated by both Europeans and Asian countries to establish modes of dominance and subjection. The accounts of Saris' and of Macartney's embassy, therefore, reveal a complex negotiation between English attempts to represent themselves as benevolent but superior trading partners and the diplomatic relations that compelled English subjection to Japan and China in exchange for commercial privileges. In this sense, the travel narrative and the ideology of trade it espouses becomes less about global economic growth and progress, and more about the means through which to mediate assertions of and anxieties about cultural superiority. While the English and other Europeans based their notions of their superiority on Christianity, individual liberty, and property, they were all too aware of the limitations of their economic and military power in the Far East. Thus, early modern documentation of cross-cultural relations offers an historic and practical precedent for the ideological questions and interventions raised by the critics discussed in the introduction--Derrida, Bataille, and Bourdieu, specifically. The impossibility of the gift posed by Derrida, the fascination with loss discussed by Bataille, and the misrecognized violence that Bourdieu identifies in gift exchange all enact themselves in what should be an equal, straightforward, disinterested economic transaction--cross- 
cultural trade. Furthermore, by examining the historical

dimensions of gift exchange and capitalism and their fundamental dependence on both overt exchange and covert obligation, we can understand more fully the ideological conflict that pervaded eighteenth century fictional representations as well. The historical economic knot of interest and disinterest that the gift and capitalism are intended to deny is revealed to be, for writers and readers of the eighteenth century, a natural, necessary, and collectively (mis) understood narrative of social life.

\section{II .}

Trade in early modern England at best was paradoxical in the consciousness of economists and traders. The language of trade throughout the seventeenth and eighteenth centuries repeatedly invokes images of mutual exchange, benefit, and equality, demonstrating interpenetrating conceptual vocabularies between capitalism and gift exchange rather than a fundamental opposition. Trade was viewed simultaneously as profit-based competition and as mutually beneficial for all involved. In George Lillo's The London Merchant, Thorowgood declares that "trade had promoted humanity...by mutual benefits diffusing 
mutual love from pole to pole." ${ }^{6}$ The idealized notion that successful trade provided global order, stability, and "mutual love" was promoted in both fiction and political tracts. John Evelyn, in his tract Navigation and Commerce: Their Original and Progress, states, "In a word, Justice and the Right of nations, are the objects of Commerce: it maintains society, disposes to action and communicates the graces..." 7 Banished from Evelyn's description is the reality of England's wars with the Dutch and the complex regulations of the Navigation Acts. The ideology of trade looks to the rhetoric of civilized society, actually turning away from profit-based competition and military conflict to situate trade as natural, moral, and as the mark of civility. Although a century later Adam Smith comes closest to recognizing the asymmetry of trade, he nonetheless acknowledges the reciprocal benefits it entails: "...trade, which, without force or constraint, is naturally and regularly carried on between any two places is always advantageous, though not always equally so, to both." These examples show that despite the capitalist nature of trade, its success depended on suppressing the differences between a restricted economy of profit and a general economy of the gift.

${ }^{6}$ George Lillo, The London Merchant, ed. Lincoln Faller in The Broadview Anthology of Restoration and Eighteenth-Century Drama., Gen. Ed J.Douglas Canfield, (Peterborough: Ontario, 2001), III.I, 9-10.

${ }^{7}$ Evelyn, 14. 
Beyond the language of mutual civility, the actual portrayal of gifts attempts to present trade in the conceptual framework of civilized cooperation, as a means to establish friendly ties rather than competing markets. The rhetoric of trade thus intersects with conceptions of the gift--both the Europeans and the Far East nations recognized the gift as a crucial aspect of diplomatic policy because it ostensibly embodied social and affective relations: pledges of friendship between distant monarchs. Evelyn and even Smith depict the negotiations of trade as universally understood, just as the gifts exchanged between countries signify an inherent naturalness, a mutual understanding of respect and generosity, that is seemingly a necessary prerequisite to trade. The gift exchanges between representatives of trading nations are depicted as the foundation of a civilized relationship based on mutual trust. This idea of mutual exchange underwrites the widespread images of circulation that describe international trade and, particularly, English efforts to open trade with Japan and extend it in China. As David Porter suggests, "The ideal of free circulation that functions as the implicit standard of cultural legitimacy in British accounts...derived from an established tradition ... which proposed the vitality of trade as the paramount measure of a nation's greatness" and "...accords it...axiomatic status with 
respect to civilized society." ${ }^{8}$ I would argue that the universal language of the mercantile age is coextensive with the language of the gift--of "reciprocal advantages" that defer the potential for conflict under the guise of benevolence and disinterested exchange. Mercantile language relied on a mutuality, "diffusing mutual love from pole to pole" and disguised its self-interest in aggrandizement by claiming that all would profit, that these capitalist ventures predicated on market value being higher than production and transportation costs would somehow add up to an equal benefit for all. The paradox is that this language of equality provoked ostensible acts of equal exchanges that were relegated outside of the market in order to secure capitalist advantage. Because English accounts treat gift exchange as an international signifier of a desire for such mutual benefit, of the many cross-cultural practices, appearances, and beliefs encountered during early modern voyages to the Far East, gift exchange is distinguished as a rare common denominator: the concept of exchanging gifts as a practice in foreign communities, between lords and servants, or between merchants of different countries is documented without fascination or novelty, but described rather as a familiar and anticipated practice.

${ }^{8}$ Porter, 198. 


\section{III.}

The gift in early modern trade and diplomacy created, as Derrida and Bourdieu suggest, always misrecognized relations of obligation. English and European traders assumed an ahistorical and transcultural function of the gift. They believed that they would present the Far East nations with gifts that registered European progress and, in return, receive equal gifts, such as advantages in the marketplace. This equitable exchange would reflect in the eyes of the other an "accurate" reflection of English self-perceptions of their status as a civilized nation. Negotiations between Saris and the Japanese began immediately upon the English arrival in Japan, and the first order of business noted in his journal was to prepare and transport presents from the King to the Japanese Shogun. This process took five days, as the crew had to travel into the city carrying the presents and then negotiate an audience with the Japanese ruler by first having the gifts inspected and then placed for a requisite period of time in the Chamber of Presents. Only after pages of describing these preparations and exchanges does Saris briefly mention in one sentence that, "we then landed our goods and registered at the Customs house" (19). ${ }^{9}$ Likewise, whenever communications were sent back and forth between the English and

\footnotetext{
${ }^{9}$ John Saris, The First Voyage of the English to Japan, ed. Takanobu Otsuka, (Tokyo: The Tokyo Bunko [The Oriental Library], 1941). Subsequent references are to this edition.
} 
Japanese, they were addressed only after a gift exchange. At one point the Shogun sent officials to Saris' ship with two vests of violet broad cloth that are thoroughly described by Saris, along with an offer to take up residence rent-free in a local estate. Saris agreed, then related what he gave in return for this generosity: "one faire silk carpet, on faire large satin Quilt, and one sash" (43). Following this account is a brief mention of the communication that occasioned the visit to the ship in the first place: the Shogun wanted to inquire, "what customs were due in and out" on goods the English wanted to trade (43). Saris' attention to the giving and receiving of such gifts does not mean, however, that there were no conflicts involved in the politics of giving and receiving presents, or the manner in which they were exchanged. For example, Saris describes his surprise at the Japanese secretary's staunch refusal to accept his present, and his claim that if he did so it would be "as much as his life were worth if he accepted any gift" (178). Although the Shogun had the secretary and other officials deliver presents to the English, the only Japanese official who could accept a present was the Shogun. Moreover, the Japanese were known for their particular emphasis on the wrapping of presents. Anthropologist Joy Hendry notes that Japanese gift-wrapping was an elaborate and accomplished practice, requiring so many layers of special paper that they were beyond practical justification. Still, these 
culturally specific practices were readily accepted by the English, and relations between Saris and the Japanese Shogun continued productively as long as the requisite presents were exchanged, and the unspoken expectation of reciprocity on-going.

While gift exchange served on the surface to foster a civilized reciprocity, a close examination of the actual gifts exchanged proves that the gifts were unequal and problematic in maintaining a restricted market economy. The list of gifts presented to Saris and his crew from the Japanese consisted mainly of agricultural commodities: cattle, milk, lettuce, chickens, hens, plantens, and lemons, to name a few. Immediately, one recognizes that these "gifts" hold immense symbolic and practical value for the giver: they comprise the natural food resources of Japan and were significant commercial objects in the Japanese market. Thus, the distinction between gifts and commodities is deliberately blurred. The Japanese, obviously familiar with the custom of gift exchange and its unspoken obligations, use their commodities as gifts to appear hospitable and welcoming, while the goods that attracted the European traders, such as cloths, gowns, silks, and varnished armors, remain in the marketplace for sale. Rather than give these over freely, the Japanese manipulate the instability of gift and commodity to cultivate social relations while maintaining a commercial advantage: the English will have to pay 
for the commercial goods they desire.

The gifts given to the Japanese by the Europeans were vastly different yet equally successful in manipulating both social and commercial relations. Instead of providing commodities with both use and exchange value, such as the food given by the Japanese, the British gave luxury items, like silk carpets, elaborately decorated napkins, satin quilts, and woolen cotton pieces--items that were rare in Japan and which were used to elicit desire for more European trade. Significantly, the goods they offered as gifts were not resources or products from England, but commodities purchased along the trade route to Japan. The English consistently tried to get the Japanese to buy cloth and clothes that were manufactured in Britain or, with far more success, that they had purchased in India or Batavia on the way to Japan. In the latter case, the English East India Company used gold and silver bullion to buy cotton goods in India in order to resell them for a profit in Japan or China. The gifts Saris mentions are used both to establish a social relationship but also to whet the receivers' appetites so that the Japanese will want to buy the items in bulk once trade has been established. The English were trying to find a market and attempting to present themselves as reliable and friendly traders who were more civil than the Portuguese and at least as civil as the Dutch. As with the Japanese efforts to use the English as a counterweight to the 
Portuguese and Dutch, Saris uses gifts to suture over an attempt to dominate the commercial arena by using the ritual of gift exchange to create for the Japanese both the obligation to reciprocate and the desire for foreign goods. Therefore, gifts, not commodities, provide the vocabulary for understanding the relationships between the East India Company and Japanese officials between 1613 and 1621 .

The obligation to give and the social expectation of fulfilling the obligation that is forced upon both parties ensures continual communication, cooperation, and assistance, which proves in Saris' journal to override monetary concerns. The gift is not represented as a bribe, but as a natural and legitimate step in the process of establishing commercial relations. But the obligation of the gift becomes a burden for the recipient and the donor, and at one point negotiations become strained. The tension is caused not by violence, deceit, or an unreasonable denial of requests, which, significantly, Saris documents in his journal, but by the failure to reciprocate a gift. After some time in Japan, Saris had a second audience with the Shogun to discuss further the trade negotiations. As with every time Saris or an English representative visited the Shogun, he brought various gifts that were offered before making any requests. However, in this particular instance, the Shogun dismissed Saris without making his return of gifts. At this, 
Saris writes: "he had not gifts to present, which truly is the greatest wrong or indignity that ever hitherto was offered to any Christian" (xxxviii). Significantly, this episode occurred soon after the English and Japanese confirmed their trade agreement in which the English were granted all of the privileges they sought except their primary request: the freedom to sell in Japan Chinese prizes that might be captured as punishment for China rejecting trade with England. Moreover, the Shogun's diplomatic snub is followed by the journal's first accounts of violence and unrest in Japan. Suddenly, Saris' account of the peaceful coexistence of the English with the Japanese is disrupted by his attention to violence within the Japanese community, including many beheadings and the burning of property and bodies. Once trade is restricted in ways that ensure that the East India Company will have a hard time competing with the Dutch, the Shogun disrupts the reciprocal exchanges that characterized English and Japanese negotiations. Moreover, this is followed by Saris' account of violence among the Japanese and against Christians. The use of the word "Christian" and Saris' sudden attention to unrest in Japan follow so closely upon one another that the narrative effect is to associate the lack of proper gift behavior with religious ignorance and brutality, a moral judgment made by Saris as a result of his recognition of the English economic subservience in the negotiations for trade. 
The ritual of gift exchange continued to inform the East India Company's trading venture in Japan even after it had been deemed a failure and the merchants recalled to England. Ironically, the development of commercial trade relations depended greatly on an economy predicated on loss; the substantial value of gifts involved drew into question the very viability of trade as a profit-making venture. Saris' final journal entries demonstrate that while the gift enabled the English to negotiate with Japan, it ultimately was detrimental to their main goal: economic profit by establishing the EIC as a carrier for trade between Japan and Northeast China. Saris states that he made it clear to the shogun that the company was leaving Firando not because of any ill-treatment from the Japanese but because of the "loss of ships and the bad prospects of the China trade" (195). However, even at this juncture, the Company was still obliged to send someone to deliver "the customary gifts" to the Shogun (196). Consequently, the time and resources required to prepare and deliver the gifts were so great that nearly six months passed before the English were ready to quit Firando. Saris' insistence on fulfilling this social duty seemingly undermines basic economic logic: the obligation to give in return for the generosity of having been allowed to establish a factory in Japan forces further economic losses because the English must stay in Firando until the gifts have been received. 
IV.

The English experience in early seventeenth-century Japan was revisited, with variations, by European nations in the seventeenth and eighteenth centuries trying to extend their limited trade to China. In 1655 the Dutch send word to the new Qing Emperor in Beijing that they were interested in establishing trading privileges in China. ${ }^{10}$ The response they received stated clearly that presents should be brought and presented ceremoniously to the Emperor. However, the Dutch intentionally disregarded this request, and their merchant was denied access to the Emperor. Significantly, the Dutch offered instead a sum of 20,000 crowns to buy their trading rights in China. ${ }^{11}$ The Emperor immediately refused the money, expressing dismay at the introduction of a non-tribute-based contract and demanded that the merchants of the Dutch East India Company (VOC) return with appropriate gifts. Rather than accept a payment to add to the treasury or to purchase foreign goods, the Chinese Emperor insists on a gesture of deference from the Dutch: he refuses the negotiation of money for trade because it implies an equal relationship between the partners transacting. Rather, the Emperor expects the Dutch to submit to his demands absolutely, or

\footnotetext{
${ }^{10}$ Jan Nieuhoff, An Embassy from the East-India Company of the United Provinces, to the Grand Tartar Cham Emperor of China; Delivered by their Excellencies Peter de Goyer, and Jacob De Keyzer, At his Imperial City of China. Trans. John Ogilby, (London, 1669).

${ }^{11}$ Nieuhoff, 23.
} 
else negotiations will not be considered. For the Chinese, the exchange of goods and money--the definitive capitalist exchange-is not an adequate dynamic with which to define the commercial relationship between their empire and European barbarians. The Emperor's demands instead rely on the gift to introduce and to control commercial negotiations. Consequently, the Dutch and Chinese are implicated in an asymmetrical mercantile relationship: once the Dutch acquiesce to the Qing dynasty's demands, they spend their time and resources in China bargaining with the exchange of gifts, only to be repeatedly denied an equivalent return--the access to trading rights that they sought. More than a century later, Macartney's embassy is much more self-conscious about the presentation of gifts and the tributary mission expected by the Chinese. Macartney embarked on his mission knowing that his orders were to secure a number of traderelated privileges, yet he brought a letter from King George III to the Emperor that defined the mission as one of honor and friendship. Although the King's instructions to Macartney were chiefly to "free the trade carried on at Canton...and obtain the exports from China on cheaper terms," in his address to Qianlong, he writes, "...above all, our ardent wish has been to become acquainted with those celebrated institutions of your Majesty's populous and extensive Empire which have carried its prosperity to such a height as to be the admiration of all surrounding 
nations."12 Even at the end of the eighteenth century, the gift functions as a productive form of diplomacy because it masks self-interest and emphasis on profit with disinterested and complimentary giving. The English did not arrive in China in 1793 to establish markets by force, make demands, or even to negotiate outright. Instead, they arrived as envoys to pay homage to a different culture, to honor the country's government with gifts, and to establish friendly and profitable ties. Unlike the East India Company ships, which were restricted to trading only at Canton with merchant associations and port officials, Macartney's ships carried no commercial goods, paid no customs duties, and were allowed to sail North to Tianjin, the port of Beijing. ${ }^{13}$ Underwriting Macartney's misson is one obvious level of awareness; the English sent word to China that they would be coming to honor the Emperor's birthday, even as the orders for the embassy were being written, all of which concerned trade negotiations. But there is also an underlying obligation inherent in gift exchange, and obligations tied the English to a mode of subjection of which they did not approve and which, unknown to them, authorized negotiations about the conditions of their subjection rather than about equitable trade and mutual benefit.

12 Horse B. Morse, The Chronicles of the East India Company Trading to China 1635-1834, 5 vols, (Oxford: Clarendon, 1926-29) 214.

${ }^{13}$ Joanna Waley-Cohen, The Sextants of Beijing: Global Currents in Chinese History, (New York: Norton, 1999) 103. 
Until the nineteenth century, China operated under a tributary system that extended to surrounding regions and to Europe. The Chinese regarded every foreign mission to their country as a tributary mission, despite the visitors' intentions. The tribute system was a "natural expression of cultural egocentricity...[Chinese] superiority was not one of mere material power but one of culture."14 Because the tribute system defined all of China's relationships with what the Board of Rites considered barbarian cultures, Qing officials expected that "the uncultivated alien, however crass and stupid, could not but appreciate the superiority of Chinese civilization and would naturally seek to come and be transformed."15 As J.K. Fairbank suggests, the Chinese projected onto all foreigners a desire to submit themselves to the Emperor, effectively erasing European desire for trade. Because the Chinese relegated the English and others to tributary status, they insisted that tribute must consist of native produce, a symbolic offering of the fruits of the tributary country. At a time when Chinese taxes were often paid in produce and foreign trade was prohibited or severely restricted, European efforts to dazzle the Chinese with examples of their technological and scientific innovation seemed, at best, bad form and, at worst, a serious violation of protocol. Trade

\footnotetext{
129-149 (130).

${ }^{14}$ J.K. Fairbank, "Tributary Trade and China's Relations with the West," Far Eastern Quarterly, 1 (1942),

${ }^{15}$ Fairbank, 132.
} 
could only occur on terms dictated by the Chinese, who prohibited the exportation of contraband goods on foreign merchant vessels but allowed regulated exports in tribute vessels that were exempt from customs duty. In these terms, the tributary system encompassed a limited foreign trade as well as diplomatic rituals. Even though the Chinese lodged and fed embassies on tributary missions, they did so out of deference due from a superior power to a tributary vassal. What the English and other Europeans failed to understand was that the Chinese would not relinquish their own expectations about the significance and usevalue of diplomatic gifts.

Macartney knew before setting sail for China that the Chinese would perceive his embassy as a tribute-bearing mission and that any attempts to negotiate trade without a presentation of gifts would be fruitless. Macartney's flagship was followed by one devoted solely to the transportation of gifts. Not only the English, but the Dutch, Portuguese, and Russians already had encountered the complex cultural implications of the Chinese relationship between vassal and suzerain. However, the King's letter indicates that this deference to Chinese wishes was one of calculation rather than of cultural admiration or respect. Macartney's voyage, according to the letter sent by the King, was to honor the Emperor on his birthday. Its language, however, recasts Macartney's real mission to secure trade advantages as an 
exchange of gifts. Before Macartney even landed in China, commercial trade intersected with the idealized gift. Rather than approach the Qianlong Emperor directly for expanded trading privileges, England first attempted to establish a symmetrical relationship based on trust and generosity. The expense of loading a ship with presents, and the cost of the presents themselves, indicate that the English expected the loss to be adequately compensated for by the authorization to establish more ports and factories in China.

Although Macartney did arrive bearing gifts, the very logic of "equitable exchange" interfered with his mission. Rather than negotiating a purely market-based exchange, Macartney was in a precarious position of having to determine Chinese conceptions of value. Since money was not acceptable as a gift, as the Dutch mission had discovered, Macartney had to determine what objects would please and fascinate the Chinese, what held a particularly high value in their culture, and what would flatter them enough to encourage their agreement to his terms. In other words, the exchange of gifts required a more tenuous negotiation of social and economic value, and such negotiations threatened the commercial enterprise because they always risked reinscribing the dialectic vision of what the gift symbolizes: equity for the English, tributary subjection for the Chinese. Rather than discussing openly an equivalent between money and privilege, the 
English and Chinese negotiate through the unequal exchange of gifts and the on-going pattern of obligation and reciprocity. The Chinese conception of the tribute-bearing mission implied that a barbarian people recognized "China's all-pervading goodness"(196). For the English, though, the "tribute" mission was a means to further their economic interests in China: their goal was not to pay homage to China's cultural superiority but to take advantage of their exotic resources, notably tea, porcelain, and silk, for import into England, sale along trade routes throughout the Far East, and re-exportation to Europe and America. Consequently, the rhetoric of mutual exchange in practice actually undermined England's mission because mutual exchange is impossible within the gift economy that they employ to symbolize their commercial intentions.

Commercial profit was relegated to secondary status soon after Macartney and his men arrived in Beijing. Believing the Chinese to be unimpressed with the list of the gifts brought over, Macartney improvised by adding to the list of presents both a private telescope and a lens that originally were brought to sell for a profit.

It appears that the expectations of the Chinese have been raised very high, by the manner in which the Embassy was announced, of the presents which it is to be accompanied with. ...they were conceived of to be of 
immense value, and when he mentioned what they were, it was thought that the Chinese would be very

disappointed. From these considerations Mr. Browne was induced to add his fine telescope to what we had already brought, and I have this day completed our apparatus with Parker's great lens, which Captain Macintosh brought out with him on a speculation, and which he has been prevailed upon to part with on very reasonable terms, forgoing all the profit which he had the prospect of deriving from the sale of so valuable and so uncommon an article. (69)

Marcartney recognized the importance of making impressive and valuable gifts and was willing to take a financial loss to impress the Chinese. Understanding the consequences of disappointing the Chinese in this diplomatic exchange, he offered up the most valuable and scientifically advanced objects--ones that otherwise promised to bring in a substantial profit--in an attempt to placate the Emperor. Short-term loss is sacrificed to the prospect of future profit. The gift becomes a way to disguise these interested relations and also a means to negotiate cultural subjection. The exchange of gifts allows each nation to defer or deny the prospect of subjection, obligation, and debt. As with Saris' experience in Japan, the gift appears to displace both 
obligations and challenges to self-conceptions of individual and national identity, and to keep in abeyance the subjection inherent in duty and debt.

On his way to the Imperial Palace, Macartney was informed that he was expected to perform the customary practice of the Kowtow. The kowtow required subjects to prostrate themselves and to perform three times in succession a bow and the "knocking" of one's head to the floor nine times. Previous European embassies had oscillated between not performing the kowtow and not adhering strictly to the exact court rituals that were taught to foreign ambassadors by Mandarins on the Board of Rites. The kowtow was the chief means by which the tributary ambassador repaid the Emperor for his generosity in arranging imperial board and lodging for the embassies; the court officials were charged to see that the emissary did the kowtow before the Emperor with accomplished ease. But the ritual itself, as seen in the debate over whether Macartney actually kowtowed, was no guarantee of admittance to the Imperial Court. In fact, some historians have speculated that Macartney's refusal to perform the kowtow was a key reason for his failure in China. For Macartney, the kowtow was a humiliating gesture that clearly demonstrated subservience to the Chinese emperor, and he therefore refused to perform it. For the Emperor, the kowtow was part of the customary tributary system in China, the system that demands the conferral of tribute 
to the Emperor before requests are made. The fact that the Chinese Emperor and Macartney argued over the proper definition of the gifts--the Emperor consistently referred to them as tribute while Macartney corrected, identifying them as presents-demonstrates, that the Emperor saw the kowtow as an extension of the tribute paid by the English with their gifts. In contrast, Marcartney sees the gifts not as tribute, but as a customary form of establishing friendly relations that he then hopes will open Chinese ports as a reciprocal gift. For Europeans going back to the seventeenth century, the acts of the ambassadors represented the acts of the sovereign. In other words, if Macartney prostrated himself before the Emperor it would be equivalent to King George III's doing so. But the Chinese, interpreting the presents as tribute, read the gifts as symbolizing the English envoy's acceptance of his subjection and expected that subjection to be legitimized by the bodily performance of the kowtow.

The question of the kowtow is significant because it makes clear the disguised subjection inherent in gift exchange. Rather than offer objects of value and novelty, Macartney is asked to physical condescend to the Emperor. Although in Chinese custom the Emperor kowtowed to God and to his parents, in Macartney's view it is far too much a physical indication of subjection. The very act of the kowtow puts the participant in vulnerable position, as he kneels and bows his head until it touches the 
floor. In spatial terms, the Emperor is elevated on his throne, and Macartney literally at the Emperor's feet. Macartney's refusal to kowtow demonstrates what the gift seeks to disguise-that for each participant of a gift exchange, the receiving of gifts is an act of subjection. Since the two cultures have very different views of what constitutes a gift, the entire process is an on-going negotiation--repeated attempts to place the receiver in debt and subjection. In the end, it is the ambiguity of the gifts and the practice of gift exchange that most defines English and Far East relations--as well as English and Far East identity.

Despite his boatload of gifts, Marcartney failed to recognize the centrality of the tributary system to Chinese culture, and his repeated deferral of diplomatic and cultural ceremony conflicted with Chinese expectations of reciprocity and subjection. As Morse notes, provisions were supplied, pilots were provided, and the transport of the Embassy and the presents was arranged for, all at the charge of the Emperor from the time they first landed in China, "but in the business for which he had come he could make no progress. They were no more than prisoners in silken bonds" (225). Morse's reference to the embassy as "prisoners in silken bonds" articulates the powers of obligation and subjection that drove relations between the English and the Chinese. The rhetoric of diplomacy, the controversy over the 
kowtow negotiations, and the performance required to sustain the official fiction that the English embassy was a gesture of friendship, displaced commercial relations; disinterested and benevolent gestures made it impossible for Macartney to broach the subject of trade and commerce. Macartney's hesitancy to discuss business during his audience with Qianlong ironically reinforced the fantasy structure that distinguishes between beneficence and profit. The Chinese, by presenting a welcoming and honorable reception for Macartney, use the English philosophy of trade to defer negotiations, the very negotiations that Macartney was instructed to pursue.

Marcartney's mission was destined to fail even before his ships set sail. The English were aware of the Chinese adamant refusal to extend trade beyond Canton. Macartney's entourage described China as a blocked, backward, and stagnant nation because the Chinese did not recognize the economic value of trade. In light of what eighteenth-century traders and economists knew about Chinese attitudes towards trade, the insistence on sending an envoy to China with a separate ship just to transport presents, and under the guise of friendly birthday wishes, demonstrates that the English believed that their gifts would obligate the Chinese to make at least some concessions. Macartney's anxiety about the quality, novelty, and value of the presents indicates that this seemingly disinterested form of 
exchange was, in actuality, a final and desperate move to force the Chinese through a means of what Bourdieu terms "symbolic violence" to give into their demands.

\section{$V I$.}

The persistent language of gift exchange, despite the East India Company's repeated failures to secure or to extend trade in Japan and China, points to the complexities of diplomatic and economic relations between 1600 and 1800. The practice of gift exchange in commercial relations emerges in the seventeenth and eighteenth centuries as a fantasy of reciprocal advantage that sutures over relations of domination and the potential for conflict. Despite the counterintuitive work of the gift in capitalist ventures, seventeenth- and eighteenth-century economists and merchants continued to describe and to justify trade in the rhetoric of the gift: mutual benefits and reciprocity. As Saris' journal indicates, however, while the gift serves as a key diplomatic tool, its gesture to civility and equality in actuality works to legitimize dominance, obligation, and subservience, for both the Europeans and their Far Eastern partners in exchange.

While each nation attempts to deny the commerce and profit gained from these relations, paradoxically, it is the rhetoric of 
the gift and the practical gift exchanges that complicate equality and provoke competition for cultural superiority. Embodied in the gifts that each culture considers valuable is an attempt to display through benevolence a cultural dominance. The narrative of the gift exchange is one that must balance precariously the fantasy of generosity and the unspoken assumption that the gift is both a market of surplus value that never can be reciprocated and an aggrieve gesture that demands a satisfactory return. Even though trade and commerce were supposedly to trump tribute and gifts as the primary form of economic exchange, the fantasy of the gift had to be maintained to suture over self-interested relations and to allow a continuance of "trade" as tribute, honor, friendship, and mutual benefit. On such ironic and half-understood self-deception rested a national identity based on the valorization of progress, profit, and enlightenment. 


\title{
Chapter ThreE
}

\section{"Comply and Live, Deny and Starve": \\ Obligation and Asymmetrical Exchange in Defoe's Roxana}

\begin{abstract}
$I$.
Early in Defoe's novel Roxana; or the Fortunate Mistress (1724), a suddenly generous and compassionate landlord rescues the heroine and her faithful maid from imminent penury. Although Roxana owes months in back rent and suffers the removal of most of her possessions by this landlord, her plight instigates a series of seemingly benevolent gestures: the landlord allows Roxana to remain in the house rent free, provides her and her maid with extravagant meals, and commits to a business partnership with the heroine to manage the lodging. But with no material property of her own to give as a return for the landlord's generosity, Roxana must sacrifice her virtue: she offers her body as an equivalent gift for his financial assistance. The obligation to give has severe moral consequences for Roxana. Recognizing that the landlord's motivations are far from selfless, she must weigh the value of her virtue against "a Principle of Gratitude" (36). ${ }^{1}$ Throughout this episode and the
\end{abstract}

\footnotetext{
${ }^{1}$ Daniel Defoe, Roxana; or the FortunateMistress, ed. Robert Clark (London: Orion Publishing Group, 1998). Subsequent references are to this edition.
} 
novel as a whole, Defoe casts the heroine's exchange of her body for material benefit in the language of the gift and obligation. The unspoken contract of gift exchange--that when one receives one must give in return--forces Roxana to give herself "up to the Devil, to shew [herself] grateful to [her] Benefactor" (36). This initial scene of gift exchange displays the complex system of debt, obligation, and authority that informed eighteenthcentury conceptions of the gift. As Roxana continues to profit materially throughout the novel, she is compelled to "ballance all obligations" (126) with the only gift that has a value for both her and the receiver. Yet her gift always invokes an ongoing circular practice because the inequality of the gifts irrevocably incites feelings of obligation and debt. As a result, Roxana spends the remainder of the novel attempting to repay a debt that in actuality never can be repaid. The unequal relationship between the material and sexual gifts demonstrates how each new gift enacts a debt that traps the participants in a series of asymmetrical exchanges that never can be completed.

In this chapter, I draw on the revisionist work of Pierre Bourdieu and Luce Irigaray on gift economies to argue that the complexities of gift exchange supplement theories of capitalist accumulation, and that a sophisticated understanding of the debts and obligations engendered by the asymmetrical logic of the gift illuminates the material and symbolic exchanges that pervade 
Roxana. ${ }^{2}$ Most critics of Defoe focus on the centrality of capitalism in his texts; critics of Roxana, such as Sandra Sherman, J.G.A Pocock, James Thompson, Michael McKeon, and Catherine Ingrassia, read Defoe as a "theorist" of eighteenthcentury capitalism who dramatizes both its virtues and its contradictions. ${ }^{3}$ I propose, however, that in Roxana, Defoe offers a crucial theoretical intervention into the discourses of capitalism. Reading Roxana as a narrative of asymmetrical gift exchange and within eighteenth-century conceptions of reciprocity reveals the novel to be less about money and business than about obligation and subjection, the symbolic means by which relations of domination were perpetuated in the period.

My reading of Roxana draws on contemporary gift economy theory, eighteenth-century conceptions of gender, business, and prostitution, and Defoe's own involvement with the period's philanthropic concerns to contest arguments that claim Roxana is an economic agent who chooses with whom she will do business, and

\footnotetext{
${ }^{2}$ William E. Hummel anticipates an aspect of my argument in his essay “"The Gift of my Father's Bounty': Patriarchal Patronization in Moll Flanders and Roxana" Rocky Mountain Review of Language and Literature, vol. 48:2 (1994): 119-41, when he describes the gifts in these texts as "vehicles for sexual exploitation" (121). However, his main argument suggests that Defoe uses gift exchange to create "emotional bonds between males and females" (120).

${ }^{3}$ Sandra Sherman, Finance and Fictionality in the Early Eighteenth Century: Accounting for Defoe (Cambridge: Cambridge University Press, 1996); J.G.A. Pocock, Virtue, Commerce, and History: Essays on Political Thought and History, Chiefly in the Eighteenth Century (Cambridge: Cambridge University Press, 1985); James Thompson, Models of Value: Eighteenth-Century Political Economy and the Novel (Durham: Duke University Press, 1996); Michael McKeon, The Origins of the English Novel: 1660-1740 (Baltimore: Johns Hopkins University Press, 2002); and Catherine Ingrassia, Authorship, Commerce, and Gender in Early Eighteenth-Century England: A Culture of Paper Credit (Cambridge: Cambridge University Press, 1998).
} 
who achieves her massive wealth through an astute manipulation of the capitalist system. Susan L. Jacobsen describes Roxana as "the epitome of commercial enterprise" and as an "entrepeneur" ${ }^{4}$ and David Durant identifies her as a "wise financier." ${ }^{5}$ This chapter, however, will demonstrate that the logic of the gift creates the fiction of Roxana's economic knowledge and agency. The gifts Roxana receives obligate her to a career as a "Woman of Business" (117), so that her narrative reconstructs capitalism not as a matter of individual ingenuity--whatever her obsessions with concealing and multiplying her riches--but as an obligation that never can be repaid. Defoe's narrative, therefore, is an account of Roxana's attempt to repay with her body the gift of financial security that her affairs allow her. The conclusion of Roxana demonstrates that Defoe ultimately condemns the means of exchange that allows Roxana her supposed financial freedom; his depiction of the collective fantasy of the gift provides only a temporary displacement of the overt violence to which she is subjected. Acts of giving in Defoe's works seem to occupy only a compensatory role, serving as a reassuring sign of benevolence, empathy, and Christian charity in a society greatly threatened by

\footnotetext{
${ }^{4}$ Susan L. Jacobsen, “A Dialogue of Commerce: Defoe's Roxana as Mistress and Entrepreneur" in Compendious Conversations: The Method of Dialogue in the Early Enlightenment, ed. Kevin Cope, (Frankfurt: Anglo-American Studies: vol. 4, 1992): 218-33, 220.

${ }^{5}$ David Durant, “Roxana's Fictions” Studies in the Novel, vol. 13 (Fall, 3): 225-236, 230.
} 
competitive economic gain and profit. In turn, the emphasis on capitalist accumulation in these texts perpetuates in Defoe's narrative worlds a fantasy that characters can distinguish between disinterested and self-interested economic principles: that gifts and sacrifice are opposed to and therefore separate from commodities and gain. This assumption is shared by critics who overlook in Roxana the complexity of gift exchange in the novel rather than interrogating the ways that these seemingly private and affective exchanges construct Roxana's self-identity and reflect a form of symbolic subjection disguised as benevolence. Defoe's texts simultaneously demonstrate in both social and fictional narratives the ways in which the principles of a gift economy are defined by the same values and motivations that determine the operation of a market system. By examining the nature and function of the gift in Roxana, I suggest that the moral corruption many contemporaries writers feared would result from a profit-based economy is best narrated not by Roxana's fall, but by the politics of a gift economy that bind her to an unending debt. In this regard, the novel's representation of the complexities of gift exchange reveals both the fiction of the disinterested gift and the intersections among gifts, obligation, and the negotiations of individual and social value. 


\section{II.}

To understand how the gift inflects Roxana's relationships as well as her fantasy of economic agency, it is necessary to interrogate her knowledge of finance in relation to her astute and anxiety-ridden recognition of her unending obligation. As Christopher Gabbard recently has suggested, Roxana's "financial acumen needs to be reconsidered, if not thrown entirely into question." ${ }^{6}$ Gabbard demonstrates the ways in which Roxana exposes herself as financially illiterate, pointing to her "admission of an inability to read 'Accompts'" and the fact that it is through Sir Robert's "successful investment strategies that she becomes an exceptionally wealthy woman." "While agreeing with Gabbard that Roxana's financial knowledge is limited, I would add that the misinterpretation of Roxana as a capitalist results from the work of the gift, which disguises her true position as a woman with limited agency in an economy governed by the laws that Bourdieu defines; ${ }^{8}$ she is always indebted and subjected to the authority of a masculine economy. What has been read as Roxana's sophisticated financial manipulation in actuality is her unwitting involvement in an unending cycle of reciprocity enabled

\footnotetext{
${ }^{6}$ Christopher Gabbard, “The Dutch Wives' Good Husbandry: Defoe's Roxana and Financial Literacy" Eighteenth Century Studies, vol. 37 (winter, 2004) 237-251, 237.

${ }^{7}$ Gabbard, 238.

${ }^{8}$ See the introduction to this dissertation.
} 
by a series of "fortunate" affairs with wealthy and generous men. In this sense, the gifts are insinuated upon Roxana and she willingly acknowledges the repost she owes for these gifts. Therefore, her participation in these exchanges must be evaluated within the vocabulary Roxana employs to tell her story: the vocabulary of obligation and loss rather than the vocabulary of capital and profit.

For most readers, the money, jewels, and clothing that Roxana receives during her affairs establish for her a basis of funds that accumulate through investment and interest. This accumulation most often is read as capital that Roxana owns and astutely manages. However, her self-description as a "Woman of Business" is undermined by her identification of each acquisition as a gift exchange that entails debt and reciprocity. In each of her affairs she openly defines herself as "bound by honor," (29) "infinitely oblig"d,"(57) "in gratitude," (109) and "indebted,"(223); her debt is cumulative and always asymmetrical. Roxana's entry into the business world, therefore, is predicated on her receiving gifts and perpetuating an economy of reciprocity: whether it is a dowry from her father, shelter and sustenance from the landlord, or jewels and clothing from the Prince, Roxana's identification of money always is in the form of a gift. As Susan Stave notes, technically any property a woman 
acquires in this period is constructed in the form of a gift. ${ }^{9}$

Wills, inheritances, dowries, pin money, and separate settlements are cast in the rhetoric of a male's generosity that obligates the female recipient to the memory and name of a patrilineal economy (which I shall argue in Chapter 4 on Burney's Cecilia). Following Roxana, a number of narratives, such as Clarissa and Cecilia to name just two, attempt to construct female ownership of property and wealth, but the obligation entailed in those acquisitions proves they never own anything but in fact owe a great deal for the privilege of enacting a fantasy of female autonomy. Rather than demonstrating a "modern" understanding of investment, Roxana describes her relationship to money and to the men who contribute to her wealth in a language of obligation and debt to an abstract patrilineal order.

The underlying confusion between capitalism and gift economy in Roxana is a product of what Pierre Bourdieu identifies as the "guaranteed misrecognition" of the gift. This misrecognition is aimed at

${ }^{9}$ Women devote their energies to finance rather than to pleasure, or "they use capital obtained through men within a sexual economy to fund their forays into a speculative financial economy (20). As historians note, women did work in the eighteenth century. Bridgett Hill and others catalogue a number of occupations performed by women, and uncover the number of women who assisted their husbands in managing business ventures. At the same time, women's participation in the economy is obscured by the tendency of eighteenth-century census takers to assign most of women's work under their male relative's names. Occasionally, women of the upper-classes are credited with the work they performed and demonstrate an agent-like relationship with money by giving to charities. Widows and unmarried daughters or sisters controlled their money but fortfeited much of their ability to control their fortunes if they married. Moreover, most women who came into money did so by receiving a gift, whether it was a bequest of a business or an annual sum left in a will. 
transmuting the inevitable and inevitably interested relations imposed by kinship, neighbourhood or work, into elective relations of reciprocity, through the sincere fiction of a disinterested exchange, and more profoundly, at transforming arbitrary relations of exploitation (of woman by man, younger brother by elder brother, the young by the elders) into durable, relations, grounded in nature. ${ }^{10}$

Benevolence and generosity become alternatives to self-interest only in that they facilitate the maintenance and reinscription of power relations through the fiction that gifts are disinterested. The fictions that Bourdieu describes allow the obligation inherent in gift exchange to be replaced by gratitude and equal sincerity, and the natural laws of opposition and domination are ostensibly displaced by mutual affection and voluntary relations. Consequently, in Roxana, gifts are mistaken for capital by both Roxana herself and by many of Defoe's readers. Because the perpetual exchange of gift and counter-gift in the novel takes place against a backdrop of investment, speculative finance, and the possibilities of individual improvement that the new economy promised, Roxana can appear as an independent, wealthy, and legitimate businesswoman able to negotiate and trade in the market. However, the seemingly disinterested exchange of gifts

\footnotetext{
${ }^{10}$ Pierre Bourdieu, The Logic of Practice (Stanford: Stanford University Press, 1990),112.
} 
highlights Roxana's inability to access independently her own wealth and to declare her autonomy. The gift produces the fiction that she chooses self-commodification and that her "capitalist" exchanges are equal negotiations of value.

Roxana's sense of obligation surfaces most dramatically in her moral self-doubt and self-recriminations. Her selfidentification in the novel is more prominently aligned with the necessity of prostitution rather than with the agency of business. Some readers, however, conflate Roxana's prostitution of her body with legitimate business: she seemingly profits from her sexual labor. This misconception is perpetuated by Roxana's own repeated references to herself as a whore, mistress, and prostitute. However, the language of the novel makes clear that Roxana's understanding of this role is not as a negotiating subject, but as an object who is bound by a debt to perform sexual labor. Roxana's ignorance of finances as well as her understanding of obligation demonstrate that her "career" as a prostitute is less an example of feminine economic agency, than an on-going effort to clear her debts, to return "equally" with a sexual labor that causes her a great deal of anguish. ${ }^{11}$ The fact

${ }^{11}$ Although women of various classes made money as prostitutes and mistresses and some enjoyed a level of influence, it was nonetheless illegal and many women were fined, jailed, and publicly punished for the crime In the eighteenth century, prostitution was not recognized as a legitimate form of business; it is described as a makeshift economy, one that falls outside of the boundaries of responsible and appropriate labor. 
that Roxana is able to accumulate wealth in exchange for her sexual labor does not allow her financial freedom but situates her in a position in which she symbolizes the gift, and each exchange of her body enacts a moral and economic loss without a sufficient return. Her body becomes, therefore, surplus, but it is a surplus of value for the men who can use it and discard it at their whim. Essentially, the gifts Roxana receives mean that her exploitation is recast as subjectivity; she becomes her debts .

While Roxana subsequently labels herself a "whore," she is never really in the position of being a prostitute forced to put a price on her favors. Although prostitutes may proclaim their economic agency, such as Angelica Bianca in Aphra Behn's The Rover (1702), the logic of capitalism undermines the prostitute's labor as subjective, profit-based work. Despite the exchange of money, the prostitute's body always occupies the position of the gift. As Luce Irigary explains, the prostitute always already is in circulation:

[They] have value only because they have already been appropriated by a man, and because they serve as the locus of relations-hidden ones-between men. Prostitution amounts to usage that is exchanged. Usage that is not merely potential: it has already been realized. The woman's body is valuable because it has 


$$
\begin{aligned}
& \text { already been used.... and has become once again no more } \\
& \text { than a vehicle for relations among men." } 12
\end{aligned}
$$

Roxana's self-identification as a prostitute entangles her in the infinite regress that results from the misrecognition of the gift. The irony of Roxana's situation is that at the same time that she strives to achieve an economic freedom and escape the necessity of marriage, she must submit to a patriarchal imperative: that she return gifts of money and sustenance with an "equal" gift, her body--the only gift Roxana has to give that embodies the dynamic of value for both the giver and the receiver. ${ }^{13}$ She can never repay her debts or meet her obligations because her sexual labor and self-identity can only provoke further instances of the asymmetries of power that inform the process of unending obligation.

\section{III.}

Roxana attempts to deny her obligation to the landlord by invoking the fiction that his generosity derives purely from a merciful nature. As opposed to Amy, who immediately suspects that

\footnotetext{
${ }^{12}$ Luce Irigaray, "Women on the Market," in Alan D. Shrift, ed., The Logic of the Gift: Towards and Ethic of Generosity (New York: Routledge, 1997).

${ }^{13}$ Furthermore, Roxana participates in unproductive labor, the antithesis of the capitalist ethic. “...the labor of the menial servant does not fix or realize itself in any particular subject or vendible commodity and seldom leaves any trace or value behind them for which an equal quantity of service could be afterwards procured," (Smith, The Wealth of Nations, Books I-III, ed., Andrew Skinner, Rev. Ed., [New York: Penguin] 430).
} 
his offer stems from an ulterior motive, Roxana invests herself in the fantasy of the gift, attempting to displace self-interest with the very vocabulary that defines it: "that's a hard thing too, that we should judge a Man to be wicked because he's charitable; and vicious because he is kind" (27). The landlord has ingratiated himself to Roxana, ironically, by "generously" giving to her the property he confiscated when she failed to pay the rent. By returning her furniture, plate, and linen as gifts, he appropriates the possessions and thereby appears to sacrifice his property out of compassion for Roxana. Roxana's initial fall into what she perceives to be prostitution comes on the heels of the landlord's sudden conversion from a ruthless creditor to a compassionate friend:

I was surprize'd, you may be sure, at the Bounty of a Man that had but a little while ago been my Terror, and had torn the Goods out of my House, like a Fury.... But now he put on a Face, not of a Man of Compassion only, but of a Man of Friendship and Kindness, and this was so unexpected, that it was surprising.

The landlord's transition occurs at a timely moment. Roxana has had to abandon her children and is on the brink of starvation. Consequently, his actions return to Roxana shelter, stability, and a comfortable life. Her gratitude then comes to be measured in terms of relief from extreme distress. As Roxana praises the 
landlord for rescuing her from starvation, she declares herself "Generously delivered," (33) and "beholden" (28). Suddenly, the confiscation of a bankrupt tenant's goods and shelter by the landlord in the name of business, self-interest, and the security of capital is displaced and a lavish and bountiful series of gifts comes to define the interpersonal dynamic between the landlord and Roxana. But the landlord's generosity merely is a way of making concrete the symbolic authority he already has over her. The fiction of the gift in the form of Roxana's returned property has erased the landlord's identity as a crass capitalist, but there is no guarantee that he will not again confiscate it; the landlord/tenant relationship has been suspended in theory only. Immediately after the return of the property, the language of the gift comes to represent not only the landlord's manipulation of Roxana, but of her self-identity as well.

Roxana clearly is aware of this tenuousness dynamic. She acknowledges early on that the gifts she receives from the landlord are burdened with implications of debt, duty, and obligation. Because Roxana does not recognize the return of the property as a return of her possessions to their rightful owner but as a generous gesture, she interprets her relationship with the landlord as asymmetrical. After his first few gestures, she anticipates that she must give something back and that indeed the 
landlord expects something in return. Roxana believes that everything she owns at this point in the narrative has been given to her by the landlord; however, the return of her property as a form of gift only displaces the fact that the landlord was responsible for their initial loss. As the landlord's gifts become more generous, Roxana questions "how should I ever make him a return any way suitable, was what I had not yet time to think of... I cou'd only say, that I should never forget it while I had Life, and shou'd be always ready to acknowledge it" (29). Her readiness to "acknowledge" material gifts cannot be restricted to mere verbal thanks. Thus, Roxana makes a return with the only form of property she believes she has to give. This exchange often is read as a capitalist transaction: she exchanges for subsistence her sexual labor. But Roxana realizes the limitations imposed upon her by receiving the landlord's "bounty": she does not choose to exchange her body in an economic transaction mediated by a general equivalent that would guarantee a universal standard of abstract value by which all transactions can be measured and evaluated, but looks to her body as a return that at least can begin to equal the generous gift of physical salvation: "I confess... I scarce had the power to deny him anything" (32). The events prior to Roxana's sleeping with the landlord are rife with her concerns about duty, obligation, and virtue. The landlord himself attempts to create a fictional 
equality by invoking the language of contract; he agrees to view Roxana as a wife and has made "an Equality" between them. These scenes embody both the elective gestures of benevolent concern for social relations as well as the interested calculation of capitalism: the landlord wants to donate his resources to rescue Roxana from starvation, but his intentions include also placing Roxana in a position to owe him perpetually.

While the landlord offers Roxana gifts that ensure her protection, the Prince offers gifts as a form of social legitimacy. The gifts from the landlord obligate Roxana because to refuse would be to starve, but the gifts from the Prince are accepted because she cannot say no. Roxana's relationship with the Prince continues her obligation to a masculine authority able to give generously. Although Roxana does not initially face the moral dilemma with him that she faced with the landlord, her complicity in the affair is predicated on her knowledge that the Prince's generosity must be returned. In this sense, the negotiation of value that occurs within a market exchange is bypassed and the logic of the gift usurps the exchange: to refuse the Prince would not only be an economic mistake but also a social transgression. The gifts embody the inequality between the male giver and the female receiver. The Prince never makes an offer that Roxana can refuse, but instead showers upon her gifts that she cannot turn down. Thus, without asking or demanding, 
Roxana becomes a "mistress" to the Prince: again, she realizes the equivalent gift for the cultural prestige of the Prince lies in her body, her only means of return. Roxana does not sell her body but is compelled to offer it as a return gift when the Prince gives her presents. Roxana admits without overtly saying so that she understands the Prince's intentions. He offers her the chance to "...make some Gentleman of quality happy, that may, in return, make you forget all your sorrows"(55) and that through their relationship she will know "what it is to oblige" a man. Their relationship is defined in terms of debt and obligation. Never does Roxana asks for payment or gifts, but rather, the Prince gives so profusely that she never has to ask.

Roxana's own assessment of her situation demonstrates that she is the Prince's mistress through obligation, rather than through economic choice: "I had now no poverty attending me; on the contrary, I was mistress of ten thousand pounds before the prince did anything for me"(71). Although she stays with the Prince for approximately eight years, she admits her inability to end the relationship and only when he says he can no longer see her does she consider herself free: "now I was at liberty..." (100). This acknowledged position of captivity and obligation displaces Roxana's financial agency. The language of capitalist commerce is not adequate enough to disguise her recognition that she has been forced into these obligatory acts through the 
seemingly innocent gesture of benevolence.

The question underwriting the novel is one which Roxana voices repeatedly: "What was I a Whore for now?" $(178 ; 179 ; 180)$ The question symbolizes her repeated loss and the unending obligation these asymmetrical exchanges entail. She first asks this question during her affair with the Prince, and later repeats it during her affair with the Lord. She recognizes throughout these subsequent affairs that there is no blatant economic reason to continue her "whoredom": "I was perfectly easie... I that had no poverty to introduce Vice, but was grown not only well supply'd, but Rich, and not only Rich, but was very Rich... (99). What Roxana fails to recognize is that her status as gift--her self as the only object she has to give--requires she remain in debt: gifts do not seal financial transactions but enact a series of exchanges that incite countergifts that, as Bourdieu suggests, perpetually mediate social relations of power. In this sense, her relationship with the Dutch Merchant is the most interesting and problematic in the novel. In this relationship more than any other, Roxana discusses openly, as a substitute for negotiation, the balancing of accounts not solely with money but with favors and gratitude. Just as is her relationship with the landlord, this relationship is predicated on the greatest gift, "saving [her] life," and creating the greatest debt of which Roxana can conceive. Significantly, by 
this point in the novel she has accumulated vast wealth, whereas when she knew the landlord she literally was on the street and starving. Still, before the Dutch merchant even implies an expected return, Roxana has decided to sleep with him, immediately correlating the gift of her body for use at his will as an equivalent for rescuing her. "I had a grateful sense... what gain he made was his due, .. and made no Advantage of me..." (109). Clearly, Roxana views the trade of her sexual labor as a means of "ballancing accounts." When the Dutch merchant hints that he will ask a great favor of her, she immediately decides that she will sleep with him, considering her body the ultimate return because she is "sensible of the Obligation I was under to him, for saving me from the worst Circumstance...I could deny him nothing" (130). Thus, Roxana does not identify her monetary wealth as an adequate return; as I have suggested previously, Roxana always has a sense that she doesn't own what has been given to her. Her insistence on repayment with her body demonstrates her anxiety that the money is not hers to give. How, then, do we read Roxana's body and the sexual labor that her body attracts and performs? Since there can be no production without capital, Roxana's body acts simultaneously as her basis of capital and her means of production. She may profit materially from this labor, and thus acquire money and status, but consistently throughout her "career" the means of production 
and social advancement lie in her body--in other words, her material profit never displaces her body as the primary object of desire that incites the process of evaluation, asymmetrical exchange, and consumption. For Roxana to act legitimately as an agent in the process of marketing her sexual labor, a third "alien entity" would have to dominate the process and embody an exchange value that both she and the men with whom she has sex could evaluate as an equivalent substitution.

Roxana depicts both the heroine's enacting of a logic of asymmetrical gift exchange and the ways in which such fictions inform and are informed by the discourses of capitalism that are associated with the eighteenth century. Capitalist exchange is predicated on the realization of both an exchange and use value embedded in the object. Goux explains, "The analysis of value can begin only when an equivalent appears on the scene. It begins with the first substitution. The value of the lost object is expressed in the body of the object replacing it" (22). The fiction of the gift is that it erases the dependence of a third entity for evaluation. In reality, however, the gift exchanges between Roxana and the men in her life inevitably depend on a general equivalent. When money and goods are given to Roxana, capitalist theory would assume that these objects obtain value by coming into relation with a second object, namely Roxana's body and her sexual labor. If she were a prostitute with a price list, 
each gift and each sexual encounter could be measured by the same abstract standard of value: money. But as Derrida recognizes, the fiction of the gift erases the transcendent mediation of the general equivalent and, paradoxically, the third entity that assigns value to the objects exchanged is Roxana's own inadequate and asymmetrical return. Thus, her physical body is exchanged as a "gift" at the same time that she must register its excessive return with the same "third entity," her body. It would seem that this creates an impossibility: how can Roxana make an evaluated and equal return when the object of value is predicated on its substitution of itself? The substitution in this case cannot exist, or it immediately cancels itself, being received and returned simultaneously--but each return puts Roxana in greater debt to the second participant. What Roxana repeatedly demonstrates is precisely the inequality of gift exchange, the loss entailed in a seemingly affective gesture, and the exploitation both perpetuated and concealed by the fantasy of the gift. The valuation that gift exchange seemingly avoids instead requires Roxana to accept willingly a substitution equivalent to loss. Thus, Roxana's gain throughout the novel is a gain of loss, her increased loss of virtue, principle, and autonomy.

Roxana's role in production, however, is to produce man's desire. Her affairs have the outward appearance of the business of a courtesan. In return for her sexual labor, she receives 
money and objects in the form of jewels, plate, and clothes. Over time, Roxana comes own "5600l" worth of goods, land securities, and a yearly income of fifty thousand pounds that she invests through the assistance of a financial manager. According to some critics, this accumulation is recognized by Defoe and his readers in modern economic terms of interest, capital, and investment, concepts that derive from the historic productions of capitalism. These terms objectify Roxana's acts as "business" and relegate them to a competitive economy. This theory, however, downplays the subjective relations of domination and authority involved in the transactions. Indeed, late in the novel, when her wealth has accrued to "two thousand fifty six Pounds a-year, Ready-Money, constantly coming in" (229) she continues to seek a position as a mistress, as a treasured object that will provoke more gifts. While there are historical examples of "fortunate mistresses" who maintained themselves by having secured a comfortable standard of living from wealthy men, there is an obvious element of fantasy in Roxana's substantial fortune. ${ }^{14}$ Roxana's wealth is predicated on the gift-so much so that she finds it impossible to give up a selective, upper-class form of prostitution and live morally on the money she has obtained. Not only does she recognize her relationship to money as that of a receiver, but she reenacts an

\footnotetext{
${ }^{14}$ One such example would be the infamous Nell Gwyn, the prostitute/actress whom some believe served as a model for Roxana.
} 
obligation to return with each gift she receives. Furthermore, despite her "success" as a "fortunate mistress," Roxana never claims to have "earned" her money, but to being increasingly fortunate in the quality of gifts she receives in exchange for her body. Importantly, Roxana never even asks for money or gifts, as the landlord, Prince, Lord, and Dutch Merchant always are more than willing to give before she can even request or demand assistance. Roxana does not negotiate, initiate, or exchange in immediate and mutual transactions with the men who keep her. Her role in these relationships is not as an independent agent involved in a negotiation of values, but as one who complies only after the fact in the exchange that has obligated her to do so. Roxana's constant fear of losing her money suggests that she recognizes her ignorance about how best to manage her fortune. ${ }^{15}$ She knows how much she has accumulated, but relies on others to decide how to keep it. Once she has acquired a substantial fortune, she enlists the help of Sir Robert Clayton (to whom she was recommended but did locate on her own) who manages her interest and investments. Initially, Roxana is reticent to take

${ }^{15}$ To understand the ways in which the asymmetrical exchange of gifts intersects with issues of gender, value, and business the eighteenth century, it is important to investigate eighteenth-century conceptions of women and business in the period. As Catherine Ingrassia points out, between the 1690s and 1753 an average of about 20 percent of the stock holdings an annuities were held by women. Women were an increasing presence in Grub Street and Exchange Alley. However, women's involvement in the speculative economy is represented as disordered. Female subjects are represented as having newly discovered "the pleasures of business" but compromise the distinction between business and pleasure "within a sexual economy focused primarily on men." Anxieties about commerce were represented in terms of the feminine. 
his advice, but each time ultimately agrees with clayton because she cannot conceive of an effective alternative; in fact, amid his insistence that she save more and spend less, Roxana admits "I knew not how to be a Miser" (208). In each of her affairs, Roxana plays a passive role in the financial arrangements. She accepts money, jewels, and goods as a gracious recipient, but the handling of her material and financial support is conducted by men. By rescuing Roxana from poverty at the beginning of the novel, the landlord assumes an authority over her belongings: he decides what to return and then secures Roxana's ownership with a contract of his making. After he is murdered, Roxana takes on the appearance of a widow with precarious finances and does not hesitate to allow the Prince to assert his economic benevolence and authority. Years later, the Dutch Merchant rescues Roxana from exposure and prevents the confiscation of the jewels which in actuality she does not legitimately own.

There is, however, an element of female financial intelligence in the novel, appropriately embodied in Amy. Indeed, Amy, the maid-servant who performs female and class appropriate work, is the most astute, responsible, and effective business person in the novel. It is Amy who repeatedly advises Roxana on concerns of money and concealment, makes numerous arrangements for lodgings and equipage, and recommends the Dutch Merchant as a source of financial advice and aid. Throughout the 
novel, she comes to Roxana's aid as a rational, moral, and moderate voice of reason, ironically in scenes in which the heroine construes her authority over Amy as business sense; in fact, she repeatedly calls Amy her "agent," recognizing her dependence on Amy's loyalty. By making Amy sleep with the landlord, Roxana, in effect, tries to make her doubly indebted-to the landlord and to Roxana herself--and to implicate her servant in the unequal economy of obligation. But Amy's primary debt is always to her mistress rather than to a masculine world of supposedly equal exchange--she can never do enough for Roxana. Ironically, the servant has a better grasp of commercial markets than her mistress. Unlike the men in the novel, Amy, who throughout enacts business exchanges, trades in gain for Roxana rather than loss. Moreover, Roxana's relationship with Amy actually denies Roxana the liberty and independence that is associated with business. She finds herself in debt to Amy for her servant's countless acts of seemingly selfless loyalty. She can repay Amy only by allowing her to continue to serve her.

The representation of Roxana as a woman amassing wealth, calculating her earnings, and discussing interest is a fiction that effectively sutures over yet another fiction: that Roxana can escape the cycle of the obligatory gift. Roxana's unwillingness to exchange her wealth means that the gifts she receives pile up and are not used: they represent a surplus, 
thereby defying capitalist ideology. Capitalist principles are guided by scarcity; gifts, however, are predicated on surplus. Roxana's relationships are based on the perpetuation of excess, thereby creating a return that is a social relationship of dominance rather than an economic relationship of equal gain. Roxana as gift is forced to stay enclosed in her apartment, she cannot perform other business with other men, and she cannot profit from the gifts because she cannot circulate them. She herself is treasured, confined, and a commodity in perpetual circulation.

\section{IV.}

Roxana herself remains a fiction throughout the novel. She imagines herself as an upper class courtesan, and appears to defy the consequences of age and repeated childbirth. Because Roxana does not legitimately own what she receives, but is rather in debt, she must always remain in disguise. A characteristic feature of the novel is Roxana's self-division: her inability to reconcile her growing bank account with her diminishing moral ethic. Her narrative is endemic of the inextricable link between women and gifts. The woman, in effect, is herself a gift--locked into a logic of self-interest and impossible obligations, obligations that never can be repaid. Her capital, therefore, is not hers to save and to invest but a gift that places her in debt 
to a masculine authority until she makes an "equivalent" return, and thus her dependence on a system of gifts encourage her to misrecognize her career as a courtesan as that of a business woman. In the language of the gift, the woman is the ultimate gift, staged as the object that mediates relations, ensures a return, and maintains the circulation of goods. Furthermore, it is her perception of herself as a gift that fosters her identification with a counterfeit identity. She repeatedly fashions herself into characters that men want--she assumes the form of desire that will make her self an appropriate return gift. As Hummel notes, "Roxana will reveal in her story that she is unable to create her own permanent identity despite (or because of) the gifts men invest in her."16 After the landlord's death, Roxana takes advantage of their supposed marriage situation so that she can benefit as a widow. Roxana is far more comfortable playing the role of the grieving widow so that she can benefit from the death of her supposed husband, the landlord. As a supposed widow, she plays at a role--the independent woman-that she can never legitimately assume as long as her husband who deserted her remains alive. Furthermore, when she dresses in the Turkish garb at the masquerade, she takes on the personae of the erotic, commodity-rich Far East, enacting in her performance for the king both a national and a masculine desire: the desire

\footnotetext{
${ }^{16}$ Hummel, 133.
} 
to conquer the foreign and to consume it, to profit from its exotic value. As the Dutch Merchant's lover and wife, Roxana appears to be to the mistress of astute husbandry, mimicking the qualities admired and accepted in Dutch wives more so than in English. ${ }^{17}$ Although Terry Castle claims that Defoe "stages the masquerade scene as Roxana's triumph--as a validation of feminine power," I would argue that the Turkish garb, as well as the role of grieving widow, astute business woman, and disinterested courtesan, are masks forced upon her. ${ }^{18}$ There is not just one "masquerade scene;" Roxana's entire sense of self-conception is a masquerade that disguises both her position as gift and the gifts she receives as masculine manipulations of power. Thus, it is even more difficult to accept Roxana as a wholly independent agent when she is forced to disguise her past, her means of wealth, and her own sense of personal identity.

The gift also informs Roxana's understanding of her debt to her children. Although she is unwilling to expose herself as a woman who survived through trading her sexual labor, when she begins to feel remorse, she looks to the gift as a means again to reconcile accounts. She finds her children and establishes them, setting them up in business and trade. She must remain anonymous, however, for many reasons, the primary reason being that she does

\footnotetext{
${ }^{17}$ See Gabbard for an in-depth analysis of Roxana's understanding of the Dutch wife's role in finance.

${ }^{18}$ Castle, 254.
} 
not want her children to feel indebted to her. Although she gives generously, she works not to interrupt the cycle of the gift by remaining anonymous. Roxana, however, suffers from her attempt in that she must disguise herself from her children at the same time that she wants to reunite with them. The responsibility of parish charity erases Roxana's past as a mother, and her part in this cycle again results in loss. Again, the logic of the gift disrupts Roxana's attempts to participate as an economic agent. As discussed in the introduction to this dissertation, a fundamental characteristic of the gift that allows it to perform ideological work is the ability of the gift to disguise origins. Gift exchange succeeds as a fantasy of disinterested exchange because the processes of production and consumption seemingly do not take place. Because Roxana embodies the logic of the gift she remains caught in an on-going effort to perpetuate her circulation as an object and thereby must deny the origins of her wealth--origins that are implicated in her need to remain hidden from her children. The source of her wealth is constantly hidden as her circulation between men is hidden. Her inability to accept this reality is her downfall, because to confront her daughter Susan would be to expose what she has fought so hard to deny--to herself and others: her subservience and dependence upon a masculine social order. To avoid confrontation, she must get rid of Susan. Roxana's refusal to reveal the truth, and Amy's 
decision to eliminate the necessity to do so by killing the girl, are the final actions before Roxana's ultimate fall. Instead of providing a conclusion to the gift exchange process that has dominated the narrative, the persistent necessity to deny the obligatory gift as it keeps the narrative in motion ultimately collapses--for Roxana and for Defoe.

\section{$\boldsymbol{V}$.}

Defoe's own investment in the charitable debates of the period inform Roxana and the problematic of the gift. In his An Essay upon Projects (1697), Defoe advocates insurance and friendly societies to provide for the poor and distressed. Later tracts, such as Giving Alms, No Charity (1728), propose projects for employing the poor, creating workhouses for vagrants, and a "College of Industry" that would employ people from area communities to work for and under the direction of the "college." But Defoe makes no pretense that his concerns for the poor are altruistic. In the preface to Giving Alms, he claims his proposals are for the good of the state and the positive perpetuation of trade: "People make trade, trade makes wealth, wealth makes cities..."(22) In fact, Defoe blames irresponsible and excessive charity as "the foundation of all our present grief" stating, "An alms ill-directed may be charity to the 
particular person, but becomes an injury to the public and no charity to the nation" (296). Defoe maintains that some gifts of charity, rather than allowing a person to reenter social life, only encouraged laziness and vice.

Roxana's declining morality is one consequence of the excessive gift Defoe warns against. It's clear from Defoe's social tracts that he recognized the motivation for giving as bound in and by the expectation of a return. Roxana's moral decline is not a product of the motivations for giving but of the obligatory nature of the gift and what excessive generosity generates: vice and a loss of virtue. The landlord's gestures are clearly excessive: they move beyond moral imperative when they become extreme; they not only sustain Roxana and Amy but allow them the opportunity to live beyond 'industry' and to ascend to a life of comparative luxury. The early scene depicting the debate between Roxana's relatives, then, sets up the duality that pervades the novel: moral consciousness versus necessity; the error occurs when the landlord lavishes upon Roxana much more than is necessary to sustain her, thus creating an excess of charity and in turn an excess of debt. Defoe's attitude towards giving distinguishes the "gifts" Roxana receives from those of economic assistance that aided the poor, elderly, and orphans and, therefore, the state.

The burden of reciprocity attached to the gift is narrated 
by Roxana's in-laws in the debate about their familial and Christian duty to her children. Following Roxana's abandonment by her brewer husband, her uncle-in-law and his wife debate the advantages and disadvantages of charitable giving. Both recognize clearly that giving entails both loss and an anticipated return. The wife insists that taking in Roxana's children will "rob what is rightfully [their] children's" (21). Her uncle-in-law, however, reverts to the Christian view of giving: by being charitable to the needy they will place themselves in a position to be "rewarded by God" (22). Both arguments rely on the structures that inform the most basic principles of a gift economy and invoke the dilemma that questions the disinterestedness of any charitable gesture. The wife recognizes that giving entails loss, no matter how kind and Christian the motives. This is the very essence of a general gift economy as defined by Mauss and Bataille. Knowing that Roxana is destitute and the children without inheritance, she reasonably concludes that their gifts of assistance will not be returned in kind. The uncle-in-law, however, views charity in spiritual terms, anticipating a return not from those whom he actually assists, but from God, in whose name he agrees to sacrifice temporal and monetary self-interest. Having already been asked repeatedly to take over the care of Roxana's starving children, the relatives are forced to take them in when they are left on their doorstep. 
Roxana's continued visits and her unquestionable reliance on the parish of the first born to assist indicate that it isn't benevolence that is expected, but the fulfillment of a duty. Defoe's writings emphasize public institutions for the poor. ${ }^{19}$ Like his contemporaries, Defoe attempts to apply a logic of equivalency to the workings of charity-non-profit making "gifts" to the indigent produce a series of consequences--trade--that promise a larger social return. As long as moral obligations can be rendered in terms of economic exchange, charity and benevolence can be reconciled to a capitalist logic--charity becomes a kind of investment. What the wife of Roxana's uncle-inlaw sees as a too generous gift, Roxana believes is expected as she views the family of the brewer husband as obligated by kinship to take in the destitute children. The novel, therefore, makes a distinction between charitable duty and benevolence. The uncle and the parish eventually take the children through a sense of moral obligation. This scene differs from those that represent giving between Roxana and the men in a number of ways, but the most significant difference is the emphasis on excess. Whereas the parish and the family are bound by state and familial obligation to assist, they do so only within reason: they give the children what they need to survive and potentially to make it on their own in the future as productive laborers contributing to

\footnotetext{
${ }^{19}$ See Maximillan E. Novak, Daniel Defoe: Master of Fcitions (Oxford: Oxford University Press, 2001).
} 
the state. The perspective of Roxana's uncle-in-law and the representation of the Parish insinuate that those gestures of charity that are a duty are finite. Roxana's gesture of a material return, however, is endless and leaves the rhetoric of religious and state duty behind to invoke a rhetoric of sin and immorality.

Therefore, the novel posits two types of charitable giving: A charity that is a duty and an excessive charity. The novel of accumulation by a woman forces her to trade in her virtue and strips her of maternal bonds by obligating her to a livelihood that is a debt. The excess of generosity puts Roxana in a position where she doesn't have to work but then her only means of repayment are through her body. The language in the first part of the novel parallels her diminishing bank account with her diminishing health. In effect, she claims that the landlord "brought her back from the dead"(36). It is safe to say that without his assistance, Roxana surely would have starved. In this context, Roxana's career and economic agency are symbolizations of excessive charity that corrupts the moral and economic wellbeing of the body and the state. 
Despite Roxana's growing wealth, she continues to accept gifts of money and material objects. While Roxana emulates Defoe's obsession with accumulation, she also reifies the dynamic of the woman as a receiver who is perpetually indebted to a masculine authority. Rather than acting as an agent, Roxana is a gift that remains in circulation mediating sites of social exchange rather than participating in equivalent transactions. Despite her growing wealth, an economic return is not feasible. As a woman who already is obligated to individual men and to a system that places her perpetually "in debt," she is not authorized to commit a business transaction or to exchange money. Although legally she can do so as a single woman, such actions do not and cannot redress the fundamental asymmetry of female debt and obligation. Her most valuable gift, which is simultaneously her most valuable commodity, is her self. Thus, the narrative ends abruptly as Defoe is unable to imagine a satisfactory conclusion to an account of the gift that perpetually incites obligation, or the fate of woman who as a recipient and a gift herself can never give enough. 


\title{
CHAPTER FOUR
}

\section{Property, Legitimacy, and Socioeconomic Debt:}

\section{The Misrecongized Gift in Tom Jones}

\begin{abstract}
$I$.
In Book III of Henry Fielding's Tom Jones: The History of a Foundling (1749), Tom sells a horse that was originally a gift from Squire Allworthy and uses the profits to assist the fired Gamekeeper Black George and his starving family. Tom parts with his horse, in which he took "more Pleasure in feeding..., than in riding..." (94) in order to alleviate "all the Miseries of Cold and Hunger" (94) that the family has endured. ${ }^{1}$ This scene is just one of many that prompts critics to align Tom with a celebrated spirit of benevolence in the novel, and to read him as one of Fielding's exemplary men of moral and civic virtue. ${ }^{2}$ These critics have read Tom's generosity as an indication of his innate goodness. Indeed, throughout the novel readers are reminded of Tom's "princely qualities," ${ }^{3}$ despite his adolescent
\end{abstract}

${ }^{1}$ Henry Fielding, Tom Jones: The History of a Foundling, ed. Sheridan Baker, (New York: W. W. Norton \& Company, 1995). Subsequent references are to this edition.

${ }^{2}$ Critics who have made this claim include, but are not limited to, Maaja Stewart, Liz Bellamy, Martin Battestin, Kenneth Rexroth, Sheridan Baker, and Patricia Meyers Spacks.

${ }^{3}$ Kenneth Rexroth, “Tom Jones,” The Saturday Review, (1968) 13-15. Reprinted in Tom Jones: A Norton Critical Edition, ed. Sheridan Baker, (New York: W. W. Norton \& Company, 1995), 675-677, 676. 
transgressions and London affair with Lady Bellaston, by his extended and seemingly unmotivated generosity--not only to his superiors, notably Allworthy, in forms of perpetual gratitude, but also to those below him and to those he does not even know-Tom assists financially at least five people during the course of the novel. Maaja A.Stewart claims that Tom's generosity to Black George and later to others arises from "a naturally noble nature" and that "he gratifies himself by gratifying those he loves." 4 In a similar vein, Liz Bellamy identifies Tom's indiscriminate generosity throughout the novel as "a natural impulse, an openhearted charity and benevolence, [free] from hypocrisy...." As Bellamy notes, "While the narrator enjoins us to prudence, the narrative points out benevolence as the most reliable code of personal conduct." 6 Moreover, Kenneth Rexroth reads Tom's "generosity of soul" as the defining feature of his "gentlemanliness," which determines the events through which his "true heritage is revealed."7 For Stewart, Bellamy, Rexroth and others, such generosity anchors the novel's moral universe. ${ }^{8}$

${ }^{4}$ Maaja A. Stewart, "Ingratitude in Tom Jones," Journal of English and Germanic Philology, vol. 89 (1990), 512-532, 514. $1998,90$.

${ }^{5}$ Liz Bellamy, Commerce, Morality and the Eighteenth-Century Novel, (New York: Cambridge UP),

${ }^{6}$ Bellamy, 90.

${ }^{7}$ Rexroth, 676 .

${ }^{8}$ Other critics that discuss generosity as the central moral value in the novel include Martin Battestin, The Moral Basis of Fielding's Art: A Study of Joseph Andrews (Middleton, Conn.: Wesleyan University Press, 1959); 
In contrast to these critics, I argue in this chapter that like all the other acts of giving in the novel, Tom's generosity can be traced to the complex burdens of social and personal debts. Tom's obligations situate his benevolence within the novel's depictions of class privilege and virtue, and show Tom, like other characters, acting on the assumption that he will receive something in return. While the obligations under which he operates as Allworthy's heir--even after he has been banished-differ from those that torment Defoe's Roxana, they nonetheless situate Fielding's hero within the complex economies of gift giving that I have described in previous chapters.

Tom's own explanation for his actions in the scene when he sells his horse clearly demonstrates that he was driven to assist the family first and foremost out of feelings of guilt. He tells Allworthy, "I could not bear to see these poor Wretches naked and starving, and at the same time know myself to have been the Occasion of their suffering--I could not bear it sir, on my soul I could not" (94). Tom's explanation shows that he does not assist the family simply because he can or because he feels naturally inclined to do so, but because he feels he must give in order to alleviate his conscience for having caused their downfall. Although Tom is not entirely without compassion for the

Bernard Harrison, Henry Fielding's Tom Jones: The Novelist as Moral Philosopher (London: Sussex University Press, 1975); and Sean Shesgreen "The Moral Function of Thwakum, Square, and Allworthy," Studies in the Novel, 2 (1970) 159-67. 
less fortunate, he acknowledges that guilt is the primary reason he sells his horse and gives away the proceeds. Indeed, Tom does bear some responsibility for Black George's fate because Black George was fired for taking part in a poaching incident at Tom's encouragement, and then punished for allowing Tom to take willingly all the blame. The hero's guilt is, in this sense, both personal and social.

In this scene, Tom's actions distinguish him from other characters in the novel--such as Thwackum, Square and Blifil, who expect to be rewarded in Allworthy's will--because he does not give with the expectation of a monetary return; however, he expects a moral return--he believes that his good deed will cancel or alleviate his debt to Black George and provide psychological relief from his guilt over the incident. Tom's later acts of giving--to Molly, Partridge, the highway robber, and the Millers--also reveal that his understanding of beneficence derives from a strict sense of duty, debt, and obligation, and not from innate disembodied notions of honor and compassion. Tom's repeated gift-giving is crucial because these acts underscore the readers' recognition both that he has internalized a complex value system based on a sense of moral obligation and that he recognizes that this obligation works in two ways. As a foundling who is the recipient of countless acts of benevolence, it emphasizes that his sense of unending 
obligation to Allworthy and to the paternalistic sociopolitical authority that he embodies is open-ended--Tom can never entirely clear this debt of gratitude. And, Tom's sense of obligation demands that he act generously in giving gifts to those below him on the social scale, both to alleviate his conscience and to bind the Black Georges of the world (at least in theory) to a hierarchical economy of privilege and patronage. In this sense, Tom's seemingly natural benevolence enacts a prolonged repayment of debt by illustrating the foundling as naturally indebted to an upper-class moral and economic authority. The illegitimate and potentially disruptive figure of the novel's foundling emerges as the hero precisely because he recognizes his debt to Allworthy and to the ideology that aligns property with moral propriety. Thus, Tom the foundling ironically becomes a legitimizing figure who willingly and repeatedly repays Allworthy's gifts of compassion and mercy by giving to others. He stabilizes the value system that depends on the yoking of property and propriety by reenacting through his willingness to give the upper-class moral authority he assumes at the end of the novel. ${ }^{9}$

\footnotetext{
${ }^{9}$ Wolfram Schmidgen anticipates my argument that Tom is a legitimizing figure in "Illegitimacy and Social Observations: The Bastard in the Eighteenth-Century Novel" ELH 69.1(2002) 133-166. He states, "In Tom's case, the bastard's susceptibility to being absorbed by his immediate environment and circumstances ensures the perpetuation of a society with a hierarchical sense of social space...the placelessness of the bastard is nothing more than the negative of place and therefore bound to reinforce a social organization based on rank," 150.
} 
In this chapter, I want to examine the emphasis on benevolence in Tom Jones and the ways in which eighteenth-century notions of generosity intersect with the period's concerns about property and ownership. My analysis of Fielding's novel contributes to the larger argument I have been making about the widespread fantasy of the gift as a means of ideological recuperation in the eighteenth century. Just as Saris' and Macartney's accounts expose the work of the gift as a misrecognized form of power negotiation, and the gifts Roxana receives disguise her indebted and dependent position, Fielding's fictional representation demonstrates the narrative of the gift as one that legitimizes traditional notions of authority while perpetuating the fantasy of a society that, at least ideally, engages in exchanges of mutual benefit and concern. As opposed to Roxana and Cecilia, however, as I will demonstrate in the final chapter, Tom Jones narrates male social and personal obligations as cast in a rhetoric of honor and gratitude, a vocabulary of the gift that reasserts the values and ideals of fading systems of patronage and feudal relations. ${ }^{10}$

Drawing on Fielding's philosophy of benevolence and his

\footnotetext{
${ }^{10}$ For a discussion of gratitude and ingratitude in Tom Jones see Stewart. For discussions of changing values within the transition from a patronage system in the early eighteenth century see J.G.A. Pocock, "The Mobility of Property and the Rise of Eighteenth-century Sociology" in Theories of Property: Aristotle to the Present, ed. Anthony Parel and Thomas Flanagan, (Waterloo, Ont.: Wilfrid Laurier University Press, 1979), 89111, and Christopher Hill, Reformation to Industrial Revolution: A Social and Economic History of Britain, 15301780 (London: Weidenfeld \& Nicholson, 1968).
} 
investment in traditional views of property, I argue that the "subtext" of benevolence in Tom Jones is in actuality the primary ideological vehicle in the novel. Gift giving in the novel reinforces through a misrecognition of the social work of the gift an upper-class moral authority. The gifts in Tom Jones circulate not as gestures of social alliance, but as ways to obligate recipients to an upper-class moral authority that in turn preserves the prerogative of material property. As I argued in the introduction to this dissertation, eighteenth-century conceptions of property and benevolence are closely related in the sense that benevolence ironically becomes a way to mediate and secure property relations that favor the land-owning classes. Because the gift always is a form of property, the ongoing debates about charity in this period and the anxieties of changing property laws offer an intriguing conflict. I propose that these two seemingly antithetical concepts--the strict ownership of property handed down through a familial line and the giving away of forms of property to strangers in the name of charity--are paradoxical concepts that are mutually reinforcing and ideally mutually constitutive. In this sense, I suggest that Fielding's novel is as much about the ideology of benevolence as a means to preserve property relations through adherence to traditional moral and sociopolitical authority as it is about the hero's acquisition of knowledge and the inculcation of 
prudence. ${ }^{11}$

\section{II.}

To understand the dynamics of asymmetrical exchange in Tom Jones, I want to turn to the work of Slavoj Zizek and revisit Pierre Bourdieu. These two theorists offer accounts of this asymmetry that can be juxtaposed to Fielding's representations of paternalistic exchange as the basis of a moral code of authority. Zizek discusses the "misrecognition" essential to capitalist exchange, and Bourdieu analyzes the concept of misrecognition in his analysis of social practices. For Zizek, misrecognition in exchange is the overlooking of the "universal, socio-synthetic dimensions" of an act. ${ }^{12}$ For Bourdieu, misrecognition is a collective act overlooking "imposed relations of kinship, neighborhood, or work."13 In drawing on both of their concepts of misrecognition, I identify a double-misrecognition as the actual practice that enables both capitalist and gift exchange. I argue that misrecognition inheres in the socioeconomic dimension of all exchange--whether capitalist, gift, or barter. The exchange must

\footnotetext{
${ }^{11}$ For discussions of the theme of prudence in Tom Jones, see Michael Mckeon The Origins of the English Novel, 1600-1740 (Baltimore: John Hopkins University Press, 2002); and Battestin, "Fielding's Definition of Wisdom: Some Functions of Ambiguity and Emblem in Tom Jones" ELH, 35 (1968), 188-217.

${ }^{12}$ Slavo Zizek, The Sublime Object of Ideology (Verso, 1989) 10.

${ }^{13}$ Bourdieu, 112 .
} 
be misrecognized as performative: each act must represent an idealized social relationship that can be rendered in terms of mutual advantages and reciprocal obligations. As I have argued throughout this dissertation, gift exchange is predicated on a necessary collective misrecognition, one that disguises relations of obligation as selfless acts of benevolence, and in the eighteenth-century--the self-titled "Age of Benevolence"--the repression or denial of this recognition provides an ostensible model for both social and economic generosity. As with the agents who exchange in the marketplace, the participants in a gift exchange must necessarily misrecognize the nature of the transaction in order for a gift exchange to take place: once the "gift" is recognized as an object with a material or calculable value that can force a return of an object or obligation of "equal" value, the gift ceases to exist, and the moral system predicated on disinterested benevolence is called into question. Critics have written a great deal about Fielding and his ideas of benevolence. ${ }^{14}$ As Sean Shesgreen notes, "...the single most important moral concept in Henry Fielding's ethical thought is the idea of benevolence or good nature."15 Most trace Fielding's notions of benevolence to the latitudinarian tradition, and see benevolence as underwriting his concept of

\footnotetext{
${ }^{14}$ The most notable of these contributions is Battestin's The Moral Basis for Fielding's Art.

${ }^{15}$ Shesgreen, 772 .
} 
good nature, a concept promoted in both his fictional and nonfictional works. Few critics, however, take into account that Fielding's traditional views of property and sociopolitical authority seem to be antithetical to his understanding of benevolence. The disinterested and selfless goodness that the novelist locates as an intrinsic part of human nature that only needs to be tapped to be put into effect is shown to emerge in a select few: "Good nature is that benevolent and amiable temper of mind, which disposes us to feel the misfortunes, and enjoy the happiness of others; and consequently, pushes us to promote the latter and prevent the former..."16 The "good man" is a benevolent man; the benevolent man is a property owner.

Halfway through Tom Jones, the narrator gives the reader a yardstick by which to measure a man's good nature. He first draws on the true story of Henry Fisher, who reportedly shot and killed his friend and benefactor to whom "he owed his Bread" and "considerable bounty" (260). The narrator asserts that no one could believably be this ungrateful. The second example presents an entirely selfless man, of whom nothing bad could be said. He is perfect--an extremely bountiful man who never takes credit for his gifts. The narrator thus asserts that no one could be this good (although he claims to know this man), and that this type of man is so rare that most people would not believe he existed.

\footnotetext{
${ }^{16}$ W. E. Henley, ed. The complete works of Henry Fielding, Esq. (New York: 1967) 285.
} 
Essentially, the narrator determines how we should evaluate the poles of human nature by situating men's characters and actions within conceptions of benevolence, gratitude, and debt. In order to assess a man's value, one must determine his relation to benevolence. Tom Jones revolves around charitable giving--it determines the characters, moves the plot, resolves tensions, and dramatizes the paradox of beneficence in the period and the cultural and material means of enforcing both moral and socioeconomic order. Tom Jones demonstrates that order is not necessarily maintained by a strict adherence to a moral and religious philosophy but to a practical and material understanding of domination and obligation.

Fielding's emphasis on benevolence in Tom Jones distinguishes a type of moral authority that is intimately connected to property ownership. The cycle of reciprocity in the novel both invokes a primitive economy through the idealized and paternal representation of Paradise Hall, a representation that seems to resist the inroads of capitalism, and shores up in the novel a moral code that preserves Fielding's sociopolitical investment in a paternalist ideology. Even as Fielding satirizes the self-interest that threatens or mocks such ideals of benevolence through the characters of Thwackum and Square, for example, Tom's adventures in the novel ultimately validate the virtues that Paradise Hall represents. As both a satirist and in 
the last third of the novel a sentimentalist, Fielding was very much a man of his time.

\section{III.}

The surest way to preserve property in the eighteenth century was to manage and often restrict its transmission, sale, and distribution. The relationship between benevolence and property thus tended, ironically, to challenge the concept of disinterested benevolence itself. The ideology of benevolence was clearly aligned with property and regulation, so that the fiction of the gift--the disinterested concern for the poor--sutured over the reality that charity was a way to monitor and control the property-less lower orders. In this sense, charitable endeavors can be read as policing actions, allowing those with the means to give the authority to regulate property and exact a moral obligation in return. In the words of John Hey, the charitable institution should regulate property ownership and preserve the ideal of selfless giving within the terms of those who give:

What we want is some contrivance which shall answer the following purposes: shall leave property secure, or even add to its security; shall leave men unconfined by civil Laws as to providing any thing for the poor beyond mere necessities; shall keep alive and nourish 
the natural power of benevolence, and yet prevent its being thrown away unthinkingly or abused ungratefully $\cdot{ }^{17}$

Hey's list of requirements calls immediately into question the "natural power of benevolence" that he wants to secure and that becomes the hallmark of an age that prided itself on the rise of charitable institutions, such as the Foundling Hospital and the Magdalen Hospital. As this passage suggests, the charitable institution arises not so much from a disinterested concern for the poor, but from the social and economic threat to the elite that economic uncertainty and the population boom of the mideighteenth century posed. ${ }^{18} \mathrm{Hey}^{\prime} \mathrm{s}$ dominant concern is property, and he clearly indicates that the drive for philanthropic institutions was perpetuated by the fears of those who were vulnerable to loss, and who thereby wanted to ensure for themselves protection from socioeconomic upheaval.

Rather than alleviating the hardships of the poor out of a genuine concern for their well-being, then, many of the philanthropic supporters of the period contributed in order to

\footnotetext{
${ }^{17}$ John Hey, Fellow of Sidney Sussex College, Cambridge, 1777.
}

${ }^{18}$ The problems accompanying financial transition in the eighteenth century have been documented by a number of critics. For representative examples, see J.G.A. Pocock The Ancient Constitution and the Feudal Law: English Historical Thought in the Seventeenth Century (Cambridge University Press, 1957) and Politics, Language, and Time: Essays on Political Thought and History (New York: Antheneum, 1971); Christopher Hill, Puritism and Revolution (London: Secker and Warburgh, 1958); and Paul Langford, Public Life and the Propertied Englishman: 1689-1798 (Oxford: Clarendon Press, 1991). 
monitor the poor through judicious aid to recipients whom they deemed worthy. As Lisa Zunshine points out, one the successful campaigns of the Foundling Hospital was to allow subscribers to observe the children they supported. On many occasions, the visitors would criticize the hospital and suggest improvements. Zunshine states, "...such civic-minded interventions would be heeded with respect, no matter how high-handed and irritating they might seem to the governors."19 Therefore, gift giving in the form of charity is intended to produce in the recipients precisely the sense of unending obligation that characterizes Roxana's behavior. For Hey, however, the implication is that institutional charity is also intended to foster a specific form of gratitude-the willingness to work and to be forever thankful for such hard labor. One of the ironies that Tom Jones poses is that such unending obligation may produce guilt but it cannot in and of itself produce individual moral reform. Fielding's satire, in this regard, is often directed against the comic misappropriations of the language of unending obligation that masks hypocrisy and self-interest.

As a foundling, Tom is hyper-aware of the socioeconomic implications of his status and the potential burden his illegitimacy imposes upon the community around him. At the center

\footnotetext{
${ }^{19}$ Lisa Zunshine, Bastards and Foundlings: Illegitimacy and its Representations in Eighteenth-Century England, (Columbus: Ohio State University Press, 2005), 192.
} 
of the novel's concerns with property and benevolence is Tom himself, the foundling who threatens traditional inheritance laws and who exemplifies the kind of social anxiety that led to the Foundling Hospital, England's first national charitable institution. The Foundling Hospital attempted to regulate bastards and raise them for a life of labor that would contribute to the economic security of the nation. The legal status of the foundling or bastard, as Zunshine has shown, was incongruent with conceptions of traditional and legitimate authority and with the potential for economic and social mobility. ${ }^{20}$ As the hero, Tom shows benevolence and goodness while he errs, and he learns from his actions to be prudent. However, in the framework of a novel underwritten by concepts of property and benevolence, Tom's illegitimacy complicates traditional narratives of social and moral authority assigned to those who gave charitably in the eighteenth century. As a bastard, Tom owns nothing and is unowned. In a period in which property is synonymous with identity, Tom is crucially marginalized and seemingly powerless. On the one hand, he can be read as mimicking a rising mobile class through his peripatetic adventures and his ultimate appointment as Allworthy's heir through his moral superiority to Blifil. On the other hand, he represents the traditional values of landed property and authority associated with Allworthy-he

\footnotetext{
${ }^{20}$ Zunshine, 156-83.
} 
seems to have an innate aristocratic nature as demonstrated through his natural tendencies to gratitude, benevolence, and loyalty. Certainly, we are given an ambiguous hero whose fate can go either way: he can remain outcast or be incorporated into the patriarchal economy of Paradise Hall. His generosity is a return for the economy of privilege that enables Allworthy to raise him as his own without any charge to the parish. In this sense, the ambiguity of the foundling's social position produces a narrative of obligation in which the foundling repays society for his acceptance into the community. Tom's adventures on the road and in London extend Allworthy's example, and his trial is not so much to learn prudence, but to enact the return of the gifts he has received. This repost becomes evidence of his exemplary moral behavior towards the upper-class and shows him to be worthy as both recipient and benefactor.

The early scene in the novel in which Tom sells his horse thus defines the crucial problem with concepts of ownership involved in gift exchange. Tom's sale of his horse points to the central conflict in the novel: ownership and the rights and liberties that attend those who own. The problem that accompanies Tom's charity and which provokes a "rebuke" from Allworthy is the implication that the horse was not Tom's to sell (94). While defending himself, Tom repeatedly refers to the horse as "your 
present," identifying the legitimate owner of the horse as Allworthy (94). Thus, the horse is at once Allworthy's possession that he puts into circulation as a present to Tom, but is also Tom's possession from which he receives pleasure and satisfaction. This confusion highlights the hierarchical relationship between Allworthy and Tom: Allworthy remains the symbolic owner while Tom is an indebted recipient of Allworthy's generosity. Thus Allworthy can accuse Tom legitimately of ingratitude, of corrupting the gift by turning it into a form of capital, a marketable commodity described by its monetary instead of its affectionate value. As Sahlines reminds us, the spirit of the gift insinuates that "what is one Man's gift should never be another man's capital."21 What this scene illuminates is the relationship between gifts and property, and the complexities of ownership that inhere in the dynamics of benevolence. Allworthy retains a level of ownership over the gifts he has given Tom, so that even through Tom's acquisition of things through others generosity, he has little authority over them. Allworthy's response to Tom's gesture is interesting for the ways in which it situates Tom's generous behavior as both good and bad form. Allworthy "now stood silent for some Moments, and before he spoke, the Tears started from his Eyes. He at length dismissed

\footnotetext{
${ }^{21}$ Sahlins, 79.
} 
Tom with a gentle rebuke, advising him for the future to apply to him in Cases of Distress, rather than to use extraordinary Means of relieving himself" (94). Tom's very unselfishness marks him paradoxically as both a generous and potentially ungrateful individual.

Much of the satire in Tom Jones stems from the ironies that exist within systems of debt and obligation. Tom's generosity, his very lack of prudence with money, distinguishes him from Blifil, whose outwardly demonstrates his obligations to Allworthy. Shortly after the scene in which Tom sells his horse, the reader learns that Tom has sold a bible, a nightgown and other items, also a gifts from Allworthy, to Blifil, for the purpose of getting money for Black George's family. Blifil, recognizing the implied ingratitude and breach of propriety, purchases the bible in order to highlight Tom's supposed transgression-appropriating a gift as property that can be transferred as one's own property or transformed into capital. ${ }^{22}$ As Stewart notes, Tom's circulation of gifts given to him by Allworthy "serve to associate Tom with poachers, wastrels, and thieves in the minds of most who judge him." ${ }^{23}$ While Allworthy is

\footnotetext{
${ }^{22}$ Ironically, it is Blifil who earlier in the novel lets lose a bird that was given to Sophia by Tom, and thus he "gives" the gift away. Interestingly as well is the narrator's mention that Tom stole the bird from its nest (IV. III, 104-105).

${ }^{23}$ Stewart, 760 .
} 
impressed by Tom's selflessness, he still rebukes him, although gently, for resorting to what he considers an extraordinary and unnecessary measure: selling a gift. In contrast to Blifil, Tom has a moral consciousness that sets him up as Allworthy's rightful heir. Tom ultimately owes Allworthy and demonstrates this gratitude by perpetuating a moral economy that circulates through gifts and debt that inevitably support the authority that makes this circulation necessary. Although Blifil does not inherit the estate that he covets, he is not totally disowned-Tom agrees to help support him with a yearly sum. Wolfram Schmidgen describes Tom himself as a gift that circulates within the community; however, in the narrative of the gift it is not people who mediate gifts but gifts that mediate people. ${ }^{24}$ Tom does not own anything; the gifts that he receives own him.

As a bastard, Tom owns no property, but seemingly would have claim to those items that Allworthy gives him. Yet, within the logic of the gift, Tom owes Allworthy a return, but he uses the money he gets from the horse and other gifts not to make a repost to Allworthy but to extend another gift to a third party. The issue of inequality disrupts the idealized operation of a system based on reciprocal obligation. Mauss would have the gift

\footnotetext{
${ }^{24}$ Wolfram Schmidgen, Eighteenth-century Fiction and the Law of Property (Cambridge: Cambridge University Press, 2002).
} 
circulate between the community to confirm this network of reciprocal obligation, which Tom attempts to do by converting the horse into cash. However, Black George then converts the cash into capital to pay his debts. When the gift leaves the realm of social mediation, it becomes an owned object that is appropriated by Tom, Black George, and then the creditors. This transformation also undermines Allworthy's claim to the presents and the relationship they embody. As gifts, they were affective gestures to reward Tom, and, as such, can be defined only by being his. Yet Allworthy believes he still has a claim to the presents and by insisting that Tom direct cases of distress to him, Allworthy reinforces his position as the wealthy property owner and Justice-of-the-Peace who evaluates actions and characters and determines punishments and rewards. In Tom Jones, the gift acts as a substitute for the market, enabling a limited circulation of goods and at the same time ensuring cohesion within the parish. The gift in Tom Jones manipulates the emerging ambiguities of property in terms of benevolence and mutual exchange that in turn reaffirm relations of dependence and the rights defended by an upper-class ideology. 
Tom Jones provides an exemplary representation of the misrecognition necessary for gift exchange to do its ideological work. Squire Allworthy's unending generosity is misrecognized by his myriad recipients in order to deny (to themselves as well as to others) the obligation they have to his authority, both before and after they receive his gifts. They also misrecognize their dependence on his mode of administering justice. Those who come before Allworthy exhibit an internalized sense of moral deference, so that they offer in exchange for justice their submission to Allworthy's ideal of civic virtue, one which privileges the rich over the poor, and the maintenance of property relations over an abstract generosity. Thus, the recipients of Allworthy's generosity and justice are made to reinforce the terms of their subjection.

As Zizek claims, the misrecognition of this fundamentally economic exchange as a reciprocal social and personal sense of mutual obligation is what makes the exchange possible. The characters in Tom Jones demonstrate this dynamic: the recipients of Allworthy's "gifts," most especially Tom, misrecognize these inherently asymmetrical relations of obligation because they misrecognize the nature of their debts to Allworthy and the socioeconomic order he embodies. Throughout the novel, the ideology of domination must be misrecognized as the rationale for 
the affective and mutual bonds of social cohesion and even quasipaternal affection. This misrecognition is best demonstrated through Tom's repeated deferral to the morality and privilege encompassed by an ethic of benevolence as a means to repay Allworthy's moral compassion--Tom's adoption of benevolence as the defining feature of his identity is in itself a form of return: it returns to Allworthy the moral character he demands from a foundling who is to become the heir of his estate and fortune. Tom's understanding of generosity and giving situates him as a representative of a class that expects consistent returns from those who are dependent, so that by the end of the novel Tom's benevolent nature makes him the ideal authority to regulate the parish and to exhort returns from the community through the perpetuation of misrecognized gestures of natural and selfless giving. Tom pays back his obligation to Allworthy by learning to become his legitimized heir.

The relationships between Allworthy and his dependents demonstrates the complex relationships between the gift and property that come into play when seemingly benevolent exchanges enforce an upper-class socioeconomic ideology. Rather than allowing the recipients to achieve a sense of autonomy, the gifts obligate them to Allworthy's moral and economic authority. For example, when Jenny is reintegrated into the community as Mrs. 
Waters, Allworthy's initial plan for her finally comes to fruition: "As to those of lower accounts, Mrs. Waters returned to the country, had a pension of 60 l. a year settled upon her by Mr. Allworthy, and is married to Parson Supple..."(640). Cleared of the crime of being Tom's mother, Jenny can return but must inevitably be subjected to the traditional, moral order which she originally was only too willing to escape at the expense of her reputation-she is married with an appropriate income. The recipients do not gain ownership or property-the circulation of the gift requires a return and this return manifests itself throughout as an obligation to Allworthy's standard of virtue, one that problematically is defined by ownership. Therefore, the gift is not the exchange of property that allows an assertion of ownership but a mechanism through which to police social and economic mobility. The gift is a fantasy in Tom Jones because the individuals who receive Allworthy's gifts remain dependent, even when individuals such as Thwackum remain resentful and hypocritically complaisant.

Most critics argue that Allworthy truly is generous for generosity sake-that he does not use his gifts to demand direct and overt submission. However, Allworthy is also, in some respect, a victim of the ideology of the gift. Rather than mediating the gift exchanges, he himself is mediated by the gifts 
he bestows. His conception of generosity is formulated within a distinct class and economic position that is not shared by those around him. Allworthy believes that he is being just and conferring his favors on worthy recipients, but often-even characteristically-he is wrong. The most prominent of these errors of course is his misreading of Tom and his unquestioned trust in Blifil for most of the novel. He expects certain responses to his judgment, mercy, and generosity and he reads both his gifts and the returns he receives (or expects to receive) as disinterested gestures. He remains unaware of the plots by others, most notably Blifil, Thwakum, and Square. For their part, the inhabitants of the parish misrecognize their indebtedness: it is not to a specific individual, Allworthy, but to a system of gift exchange, the process that binds them to an economy of obligation because they do not have the resources to engage in a market economy, own land and give gifts. Ultimately, the gifts that define Allworthy's relationships to his dependents are not simply objects with value but legitimacy and moral selfidentity. As Mauss points out

the nature of the legal tie that arises through the passing on of a thing is mythical, symbolic, imaginary, and for that reason all the more exacting. Since the gift is an expression of human solidarity, and involves 
the imagined oneness of a community, the failure to honor the tie is to reject the bond of alliance and commonality ${ }^{25}$

Because those in the parish are dependent on Allworthy's generosity for financial support and for the justice that regulates their lives, they accept his gifts and thus, in theory, accept the debt they owe him. The relationship between gifts and eighteenth-century conceptions of property works in this novel not only as a system of loss and continual circulation of goods throughout the community through repost, but, ironically, as a means of a securing, stabilizing, and increasing private property. In this respect, Allworthy's gifts reinforce an upperclass socioeconomic order that obligates the lower economic classes to a moral authority and asymmetrical social cohesion. To recognize one's debts is virtue; to evade one's obligations marks a surrender to ingratitude, self-interest and vice. Those who merit his rewards are then given monetary gifts-annuities, living, sums of money-but these are only enough to sustain them within the class status of which they already belong. Allworthy does not enable them to be mobile individuals in the new economy, but restricts them to a tradition, carefully controlled economy predicated on the squire-the symbolic paternal figure-judging

\footnotetext{
${ }^{25}$ Marcel Mauss, “Gift, Gift,” trans. Koen Decoster in Schrift, 28.
} 
them worthy to receive their gifts.

In contrast to Thwackum and Square, Allworthy may seem an ideal instance of prudent conduct, though many critics have pointed out his gullible nature and quick, and therefore often incorrect, judgments. ${ }^{26}$ As a Justice of the Peace, he is authorized to distribute justice, pronounce sentences on criminals, and display charitable leniency on those whom he deems fit. Both Black George and Partridge are victims of his asymmetrical justice. The narrator takes pains to point out when describing Allworthy that

$$
\begin{aligned}
& \text { there was no one in the Kingdom less interested in } \\
& \text { opposing that Doctrine concerning the Meaning of the } \\
& \text { Word Charity,...So as no man was ever more sensible of } \\
& \text { the Wants, or more ready to relieve the Distresses of } \\
& \text { others, so none could be more tender of their } \\
& \text { Characters, or slower to believe any thing to their } \\
& \text { Disadvantage (my emphasis). }
\end{aligned}
$$

In fact, Allworthy is very quick to judge. When Partridge is accused of infidelity and of being Tom's father, Allworthy allows him to plead his innocence. However, when Jenny cannot be found to corroborate Partridge's claim, Allworthy passes judgment

\footnotetext{
${ }^{26}$ For representative examples see Shesgreen, Battenstin, and Stewart. Also, Eric Rothenstein, "Virtues of Authority in Tom Jones," The Eighteenth Century28.2 (1987).
} 
quickly based on his own moral standards and judgements rather than any sufficient evidence:

Mr. Allworthy then declared that the Evidence of such a slut as she appeared to be, would have deserved no credit; but he said he could not help thinking,...she must have confirmed what so many Circumstances...did sufficiently prove. (68)

The ambiguity of Allworthy's character arises from his gifts binding him to a sense of social obligation rather than his regulating the dispensation of gifts. At the beginning of the novel the readers learn that Allworthy had intended to give Jenny in marriage "together with a small Living, to a neighbouring Curate" (36). This ambiguity is evident both early and late in the novel in his relationships with the women of the parish, and the ways in which women are judged by Allworthy's moral rather than legal standards.

The conflict between property as gift and property as identity first becomes apparent when Allworthy applies the poor laws to Jenny. When he administers the poor laws to Jenny he is merciful and forgiving, and in fact, members of the parish feel he is too lenient: "...' it was universally apprehended, that the House of Correction would have been her fate" (41). However, at the same time he insists that Jenny commit to a specific moral 
code, and she is removed from the parish. The child is kept and cared for by Allworthy and thus he removes the burden of care for the foundling from the parish. Allworthy's form of justice implies that he too sees his gifts of justice and mercy as binding him to an obligatory logic of guardianship and moral and political responsibility. His mercy to Jenny gives him the authority later in the novel to reassert his authority over her when she is discovered to be Mrs. Waters. The consideration that he shows her demands that she demonstrate her submission to his authority and thus justifies Allworthy's later giving Jenny away in marriage. Furthermore, at the novel's conclusion he appoints Molly as Partridge's wife, and thus adopts a paternal authority over the subjects of the parish by enacting a right "give" them in marriage. Essentially, the parish is an extension of Allworthy's property and his assistance to its inhabitants binds them to the dynamic of obligation by convincing them that they are rightfully and honorably subjected to Allworthy's power. The fiction of the gift recasts this subjection as gratitude. The Millers, for example, are thankful for the gifts because Allworthy"s "generosity" disguises their true socioeconomic positions. In justifying her authority to regulate Tom's behavior, Mrs. Miller invokes her obligation to Allworthy: Mr. Allworthy placed me in the House where you now see 
me, gave me a large Sum of Money to furnish it, and settled an Annuity of 50 l. a Year.... Do not think me impertinent ...if I beg you not to converse with these wicked women. (491)

On more than one occasion, Mrs. Miller refers to Allworthy as her Benefactor and thus regulates her household in London on terms she believes he will find acceptable. Thus, his recipients see themselves as an extension of an ideology of benevolence and property-not as subjects to the rule of an authoritarian governor but as children protected and rightfully admonished by a caring paternal figure.

The inconsistencies in Allworthy's judgments occur because instead of moderating justice and exchange he himself is moderated by it. The idealized reciprocity of obligation and debt-and the problems of actually living up to such ideas-are evident in the relationship between the squire and his adopted heir. Allworthy gives Tom his name, he inculcates him into the value system defined by propriety and asks to be referred to as father. This relationship binds Tom to Allworthy, and Tom is repeatedly punished for his transgressions that seem to violate this relationship. Tom is exiled from Paradise Hall because of ingratitude, because he fails to reciprocate adequately a return for the Squire's generosity. Allworthy insists that Tom's return 
adhere to a specific moral standard-the same that he asks of Jenny, Molly, and for which he ultimately condemns Black George. Deference to Allworthy's generosity is more important than any material repost. Even after Tom is exiled from Paradise Hall and takes to the road, his sense of generosity, obligation, and virtue reinforce the values associated with squire Allworthy. He does not convert any of the gifts to cash but gives what he gets from Lady Bellaston to others.

In an important sense, much of the novel explores how Tom comes to attain and deserve the money and property that he is always willing to give away. Tom clearly has an idea of proper ownership and a value for property-he refuses to break sophia's bank note so that he and Partridge can travel easier or rest for the night or even purchase food. When Partridge tries to convince Tom to spend the bank bill instead of starving, his pleas are "rejected with disdain" (459). Later, when Tom gives 50 pounds to Mrs. Miller to give to her indigent cousin, Fielding himself notes the reader's curiosity about the source of his wealth and clarifies that the money had in fact been given to Tom by Lady Bellaston. We recognize the strong moral conscience that is presented as innate in Tom when he sacrifices all the money that he has to his name, even while he wonders how he will get by without it. Because Fielding identifies this money as a gift, it 
therefore represents something other than Tom's property to give. By giving away the 50 pounds, Tom circulates the gifts he has received in his kept status-however questionable his sexual behavior may be-to maintain the needy. Tom's indebtedness to Lady Bellaston serves the greater good-he is able to give to the highway robber who turns out to be a desperate father. Unlike Roxana, who accumulates gifts but withholds them from circulation, Tom practices generosity when he has little means to do so.

Tom's relationship with Lady Bellaston has been a problem for critics; indeed, the inequalities of gender show Tom trading his sexual labor for subsistence, but at no time does Tom or anyone else-including the narrator-call him a "whore" the way that Roxana is labeled by herself and society. In fact, Rexroth sites all of Tom's relationships with women as "motivated by the desire to please or help" and describes his response to seduction by both Mrs. Waters and Lady Bellaston as "the reaction of a generous man to generosity." ${ }^{27}$ While Tom and Roxana both are obligated by the gifts they receive, their gender determines how readers perceive them. Roxana clearly is consciously repaying a debt with her sexual labor-she is an obligated debtor-while Tom reinforces an upperclass morality even within a system of loss

\footnotetext{
${ }^{27}$ Rexroth, 676.
} 
and obligation that prepares him for his inheritance of both Allworthy's estate and a paternalistic moral authority. This point will be taken up in more detail during my discussion of Cecilia in chapter five, but for now it is important to consider that Roxana's narrative ends in disaster, Cecilia's in "resigned contentment" and Tom's with "the entire community praising the day he married his Sophia" (641). In this respect, the narrative of the gift rewards a male authority that can give away property as a means to ensure socioeconomic stability, and chides female attempts to exert authority over property. Tom's return, his sexual labor, is articulated as gratitude even in his relationship with Lady Bellaston, while both Roxana and Cecilia identify their returns as debts that never can be repaid.

In this respect, Tom recognizes that his relationship with Bellaston confers on him an obligation. He consents to the relationship so that he can get financial assistance and find Sophia. As Spacks states, Tom's exhibits "a mistaken sense of honor and a genuine sense of gratitude."28 Many critics read this as one of Tom's faults, but one that actually reaffirms his status as hero because, according to Fielding, no believable character in a history can be too perfect. However, his

\footnotetext{
${ }^{28}$ Patricia Meyers Spacks, Desire and Truth: Functions of Plot in Eighteenth-century English Novels (Chicago: University of Chicago Press, 1990), 82.
} 
willingness to sleep with Lady Bellaston for money also shows that Tom is aware of the intricacies of obligation and debt, and the underlying interestedness of benevolence: "He knew the tactic consideration upon which all her Favours were conferred; and as his Necessity obliged him to accept them, so his Honour, he concluded, forced him to pay the Price" (463). The obligation he has to Lady Bellaston (like the one he feels to Black George)differs from other obligations in the novel because Tom often gives to others to whom he seemingly has no obligation, particularly, the would-be thief and Mrs. Miller's family members. Although Lady Bellaston gives money to Tom, enacting openly an exchange of sexual labor, she dismisses her obligation to the poor and refuses to marry Tom. Lady Bellaston and Tom engage in reciprocal obligation but the marriage proposal (though false) exposes the fiction that Lady Bellaston is a giver motivated by Allworthy-like benevolence: she may exchange her money and her body for Tom's sexual "gratitude" but she will not marry a man without money or prospects. Lady Bellaston seems like one of Hey's beneficiaries of institutionalized charity-the gift keeps the lower orders in their place.

\section{$\boldsymbol{V}$.}

The final sentence of the novel focuses not on Tom's 
personal education or on his knowledge of prudence and selfregulation, but on the passing of Allworthy's wealth to Tom and the continuance of gift exchange through Tom and Sophia's generosity. The novel, therefore, affirms a concept of material circulation that is in fact static, that supports a traditional status quo. The gift informs Tom Jones as much as moral knowledge and prudence; in fact, the vocabulary and logic of the gift underwrite the novel's conception of morality and knowledge, so that these are supplements to achieving and maintaining a communal form of exchange that ultimately legitimates and reifies upper-class authority through the ownership and preservation of property. The final sentence of the novel articulates precisely Fielding's purpose of a peripetitic novel that ends precisely where it began. The narrator states of Tom and Sophia,
And such is their Condescension, their Indulgence, and their Beneficence to those below them, that there is not a single neighbor, a Tenant, or a Servant who doth not most gratefully bless the Day when Mr. Jones was married to his Sophia. (641)

The satisfactory conclusion is dependent upon the reassertion of the divide between those who give and those who receive. While Tom has learned to mediate his vices through the lesson of prudence, the community is sealed by the comfort that Tom and 
Sophia are the generous authorities of the parish. However, the final sentence throws these concerns into relief as the real issue-one of ownership of property and the right to give it away-is reconciled by Tom's assuming the crucial role of the generous squire. 


\section{CHAPTER FIVE}

\section{'Her Gift Was Compelled' :}

\section{Gender and the Failure of the 'Gift' in Cecilia}

\section{I.}

Throughout the first half of Frances Burney's Cecilia; or Memoirs of an Heiress (1782), the heroine engages in what she believes are disinterested acts of generosity. Orphaned, single, and heiress to a large estate, Cecilia adopts a sense of fiscal and moral agency as she awaits her twenty-first birthday . Although legally under the authority of three guardians, she considers her money hers to spend and regards herself as "an agent of Charity, and already in idea anticipated the rewards of a good and faithful delegate..."(1:52). ${ }^{1}$ Cecilia's scheme for happiness through philanthropy arises from her almost immediate dissatisfaction with her life in London and in the Harrel household. Unable to find in the world of fashion the human intimacy she had cherished when in the care of an "aged and maternal counselor" $(1: 6)$, she commits herself to acts of

${ }^{1}$ Frances Burney, Cecilia; or Memoirs of an Heiress, ed. Peter Sabor and Margaret Anne Doody (New York: Oxford University Press, 1988). Subsequent references are to this edition. 
charity, convinced that they promise social and moral authority. As Kristina Straub points out, Cecilia views giving as a way to "enable herself to act and initiate rather than being acted upon;"2 she truly believes she will succeed in making "worthy use of the affluence, freedom and power" she possesses (1:55). At the same time, Cecilia considers her fortune "a debt contracted with the poor, and her independence, as a tie upon her liberality to pay it with interest" (1:55, my emphasis); or, as Catherine Gallagher states, she believes that "she owes whatever she owns." 3 The novel, however, works to undermine her belief in unalloyed generosity; she is both impractical and mistaken in her assumptions about self and socioeconomic obligation. Confusing benevolence for "DUTY" and with "a fervent desire to ACT RIGHT," (1:55) Cecilia formulates a plan to give, and to give generously-a plan that, from its inception, never enacts the disinterestedness she covets. Rather, it entangles her in an ethical dilemma of financial obligation, threatening both her fortune and identity. Cecilia's intended acts of generosity are revealed to be instances of coercion as she quickly finds herself giving her money to the most unlikely of recipients, such as her

${ }^{2}$ Kristina Straub, Divided Fictions: Fanny Burney and Feminine Strategy (Lexington: University Press of Kentucky, 1987), 123.

${ }^{3}$ Catherine Gallagher, Nobody's Story: The Vanishing Acts of Women Writers in the Marketplace, 16701820 (Berkeley: University of California Press, 1994), 238. 
guardian Harrel, and the most unworthy of causes. In actuality, her acts of gift-giving and charity are compelled acts in response to a paternal debt-a debt that, by its very nature, can never be repaid and always is experienced as an imposition.

This chapter examines the intersections among gift economy, paternal authority, and the patriarchal structures that inform Cecilia's understanding of the "gift" and its social implications. As a novel written by a woman, Cecilia depicts the heroine's relationship to the complexities of gift exchange in ways that differ subtly from the analogous portraits of Defoe and Fielding. The problems within the novel provoked by an economy of gift exchange have both historical and theoretical dimensions, and, in this chapter, I want to examine how the dilemmas that confound Cecilia locate Burney's novel within eighteenth-century debates about women's roles in philanthropic giving and expose the problems posed by the mutual implications of gifts and obligation. The gift-particularly the heroine's "gift" to the Harrels, her acts of "charity," and the love exchange between Cecilia and Mortimer-sutures over her complicity in a patrilineal and repressive economic system. The novel's representation of the complexities of gift exchange exposes what Derrida terms the "impossibility" of the gift and presents interested and exploitative exchange as disinterested generosity and voluntary 


\begin{abstract}
charity.4 My reading of Cecilia, in this respect, draws on debates about the nature of gift exchange to contest arguments that the heroine acts in accordance with eighteenth-century conceptions of social responsibility. Critics such as Terry Castle and Catherine Gallagher read Cecilia's capitulation to a patriarchal economy ultimately as informed, socially aware, and voluntary. ${ }^{5}$ Similarly, Barbara Zonitch states that "practicing charity is the key to female self-empowerment in Cecilia," (78) and Catherine Keohane argues that Cecilia's giving in the novel offers the possibility of female agency through charitable participation in the public sphere. ${ }^{6}$ Keohane states that the novel's focus on charitable giving signifies Cecilia's "authority to distribute money while single" and her "belief that
\end{abstract}

${ }^{4}$ Jacque Derrida, Given Time: I. Counterfeit Money, ed. Peggy Kamuf, (Chicago: The University of Chicago Press, 1992. See also the introduction to this dissertation, "The Impossible Gift in the Age of Benevolence," for a thorough discussion of Derrida's theory of the impossible gift and its intersections with other gift economy theories.

${ }^{5}$ Terry Castle, Masquerade and Civilization: The Carnivalesque in Eighteenth-Century English Culture and Fiction (Stanford: Stanford University Press, 1986), 253-289. Castle states that the benevolent projects Cecilia engages in "have the status of voluntary acts: she takes 'exquisite satisfaction' in relieving others from penury. Yet in light of displaced authorial intentions, Cecilia's charities might be seen as enforced: they represent the theme of repayment in its morally sentimentalized form. ...nevertheless, to the extent that Cecilia does begin to divest herself of wealth, she prefigures her later acts of voluntary self-impoverishment...." Gallagher, 203-256. Gallagher states that "the heroine very gradually loses her fortune through a series of painful extortions. Nevertheless, each expropriation displays Cecilia's moral consciousness, that is, the consciousness that she is already in debt."

${ }^{6}$ Barbara Zonitch, Familar Violence: Gender and Social Upheaval in the Novels of Frances Burney (Newark: University of Delaware Press, 1997), 78. Catherine Keohane, “'Too Neat for a Beggar,' Charity and Debt in Burney's Cecilia,” Studies in the Novel, vol. 33 (winter 2001): 379-401. 
she has a right to choose what to do with it."7 Despite the overt connections in the novel among violence, coercion, and giving, Keohane and others align all of Cecilia's acts of giving with a "traditional model of hospitality" and responsible charity. ${ }^{8}$ That is, they hold open the possibility of the disinterested gift as an alternative-even if only an idealized one-to an exploitative, masculinist, and capitalist economy. In countering this reading, I examine scenes in the novel that expose the impossibility of the gift and the limitations of female agency even within networks of charity and social duty. Specifically, Cecilia's appearance at the masquerade, her relationship with Mr. Harrel and her other guardians, and the consequences of her courtship and marriage with Mortimer demonstrate ways in which women are compelled to assume a socioeconomic identity that allows them temporarily to act as though their giving can suspend or somehow transcend the inequalities of a male-dominated economic system

To understand how Cecilia forms her assumptions about her social and familial obligations to give and the ways in which these assumptions are defeated, it is helpful to understand the status of women's charity in the eighteenth century. Although

${ }^{7}$ Keohane, 383 .

${ }^{8}$ Ibid, 384. 


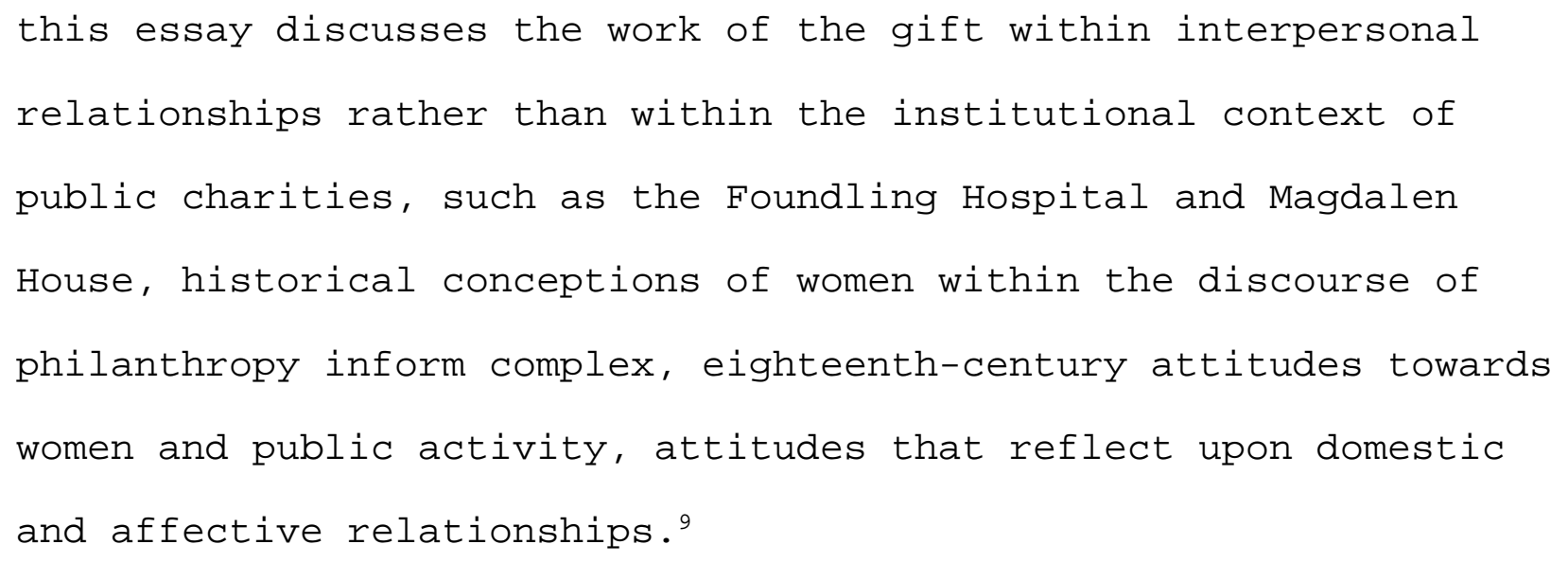

As historian W. K. Jordan notes, the number of female donors to charitable organizations in England rose steadily before and during the eighteenth century. However, the limited legal status of women and their restricted involvement in public life makes any specific number unreliable; Jordan observes that the numerous gifts from women were "in all cases...credited to the husband."10 A recurring problem is our inability to discern the extent to which women were following their husband's or their family's wishes, acting on their own, or having males in the family donate in

${ }^{9}$ The relationship between gifts and philanthropy is complex and beyond the scope of this essay. For studies regarding gifts and charitable exchange in the eighteenth century, see Donna T. Andrew, Philanthropy and Police: London Charity in the eighteenth century (Princeton: Princeton University Press, 1989); Margot Finn, The Character of Credit: Personal Debt in English Culture, 1740-1914 (Cambridge: Cambridge University Press, 2003) Beth Fowkes Tobin, Superintending the Poor: Charitable Ladies and Paternal Landlords in British Fiction 1770-1860 (New Haven: Yale University Press, 1993); Roy Porter, "The Gift Relation: Philanthropy and Provincial Hospitals in eighteenth-century England," in The Hospital in History Lindsay Granshaw and Roy Porter, eds. (London: Routledge, 1989), 149-78; and Lisa Zunshine, "The Gender Dynamics of the Infanticide Campaign in Eighteenth-Century England and Richardson's History of Sir Charles Grandison" in Writing British Infanticide: Child Murder, Gender, and Print, 1722-1859, ed. Jennifer Thorn (Newark: University of Delaware Press, 2003).

${ }^{10} \mathrm{~W}$. K. Jordan, The Charities of London 1480-1660: The Aspirations and the Achievements of the Urban Society, (London: Ruskin House, 1960), 353. 
their names. The true status of women's charitable participation and the gender politics entrenched in eighteenth-century philanthropy is revealed in the complicated ways in which women were both committed to and excluded from public charities. Lisa Zunshine notes that female participation was both crucial to and problematic for one of the period's most well-know charities, the Foundling Hospital. ${ }^{11}$ Zunshine observes that the support of upper-class women in the campaign for the hospital was encouraged and highlighted: "correspondence between the Hospital and its Govenors attests to the crucial role played by women...in the functioning of the charity." ${ }^{12}$ However, she adds that by the early 1740 s "women ceased to lend their names to the public support of the hospital all together."13 How and why women resisted public acknowledgment of their giving remains another key historical problem. Ruth McClure suggests that women withdrew from public support of the Foundling Hospital because they were "...unaccustomed to the burden of governing a public charity...."14 Donna Andrews, more pointedly, views the exclusion

\footnotetext{
${ }^{11}$ Lisa Zunshine, Bastards and Foundlings: Illegitimacy and its Representations in Eighteenth-Century
} England, (Columbus: Ohio State University Press, 2005).

${ }^{12}$ Zunshine, 153.

${ }^{13}$ Ibid.

${ }^{14}$ Ruth McClure, Coram's Children: The London Foundling Hospital in the Eighteenth Century (New Haven: Yale University Press, 1971), 46. 
of women as enmeshed in crucial social, moral, and ideological values:

$$
\begin{aligned}
& \text {...the absence or presence of female subscribers can be } \\
& \text { taken as an indication of the "reputation" of the } \\
& \text { charity, that is, of its supposed tendency to increase } \\
& \text { or decrease vice while relieving affliction. Both the } \\
& \text { Foundling and the Lock hospitals listed no female } \\
& \text { subscribers, though the former had sent a petition } \\
& \text { signed by a host of noblewomen to the king, and the } \\
& \text { latter indicated that they received donations from } \\
& \text { women who had requested that their names not appear on } \\
& \text { any public lists. }{ }^{15}
\end{aligned}
$$

These requests by women to remain anonymous indicate their awareness that even ostensibly disinterested acts of charitable giving come with costs, obligations, and consequences. Although women contributed to charities such as the Lock Hospital and the Lying-in Hospital, the masculine and paternal anxieties about female benevolence that women internalized dictated the ways in which their giving was represented.

In both social and literary texts, women writers in

\footnotetext{
${ }^{15}$ Andrews, 72.
} 
particular often take pains to present their giving as an act of agency that reinforces, rather than usurps, masculine prerogatives and paternalistic values. As Beth Fowkes-Tobin points out, women authors, most notably Hannah More, defined responsible charity for middle and upper class women by arguing that the traditional purveyors of benevolence, such as the clergy and the gentry, had failed in their duty to attend to the poor. In turn, these writers asserted that because women had "mastered the microtechnologies of self-regulation, [they] could change the hearts of the poor, teaching them to accept with humility and gratitude their place in the paternal order."16 As Tobin's analysis suggests, female philanthropy was tied to the reinforcement of masculinist values, so much so that women's involvement in the public sphere ironically was formulated as rescuing failing patriarchal authority. Paradoxically, in its ineffectiveness, a dominate masculine ideology continued to define social order by assigning a feminized moral authority to regulate the moral economy of seemingly disinterested philanthropy. Thus, the benevolent agency that late eighteenthcentury women appeared to regulate in actuality worked to reinforce the very system that limited their public activity: their charitable aims and education promoted among the poor duty

\footnotetext{
${ }^{16}$ Fowkes-Tobin, 123.
} 
and deference to an exploitative and morally indifferent hierarchy. Burney herself knew well the middle-class conviction that charity bound the poor to an ongoing debt that required they accept their place in the social order. In regards to the orphans aided by the Foundling Hospital, she states "they were to be trained up to useful purposes, with a singleness that would ward off any ambition for what was higher, and teach them to repay the benefit of their support by cheerful labour." ${ }^{17}$ As Cecilia demonstrates, female benevolence certainly had its place in the eighteenth century, as long as women's charitable efforts reinscribed masculine and hierarchical values. Chief among these values was women's self-regulation of their own desires for an independent economic agency expressed through such gifts.

\section{II.}

In addition to the problems associated with female charity, the gift poses particular problems in Cecilia because the culture the novel critiques through an emphasis on charity is one dominated by public credit. ${ }^{18}$ As Derrida's description of the

\footnotetext{
${ }^{17}$ Frances Burney, The Diary and Letters of Frances Burney, Madame d'Arblay, ed. Sarah Chauncey Woolsey (Boston: Robert Brothers, 1880), 135.

${ }^{18}$ For discussions of Burney's critique of public credit in Cecilia, see D. Grant Campbell, "Fashionable Suicide: Conspicuous Consumption and the Collapse of Credit in Frances Burney's Cecilia," Studies in Eighteenth-Century Culture, vol 20 (1990), 131-145, and Keohane.
} 
gift makes clear, gift exchange is impossible because it always is implicated in notions of debt and return. In this respect, the conditions that define the disinterested gift cannot be articulated without invoking a rhetoric of credit and the practices that define credit relations:

\begin{abstract}
For there to be a gift, it is necessary that the donee not give back, amortize, reimburse, acquit himself, enter into a contract, and that he never have contracted a debt. There must be no reciprocity, return, exchange, countergift, or debt. If the other gives me back or owes me or has to give me back what I give him or her, there will not have been a gift.... ${ }^{19}$
\end{abstract}

The staging of gift-giving eludes the possible since the moment the gift presents itself as gift it simultaneously is annulled. Because it is necessary that the recipient not give back, it also is imperative that at the same time he or she not acknowledge the gift as such; recognition of the gift as gift implies a restitution in that it demands in exchange a "symbolic equivalent;" it "perceives the gift...the intentional meaning of the gift...[and] this simple identification of the gift seems to

\footnotetext{
${ }^{19}$ Derrida, 13.
} 
destroy it."20 The gesture of the gift in Cecilia-for example, her "loan" of money to the profligate Harrel-presents itself as a paradoxical instance in the sense that Derrida suggests: "the gift is never truly a gift but instead a symbolic transaction that must take the form of the gift for it to be recognized." ${ }^{21}$ The impossibility of the gift that Derrida identifies is what allows gift-giving to perform an act of ideological recuperation in the novel, one that is subjected to compulsive repetition in order to be sustained. For instance, in order for Cecilia's "gift" to repair Harrel's economic disasters, it must appear as a gift, but, in actuality, perform the work of a loan.

In both modern and primitive societies, the language of debt and the implications of extended credit interrupt the idealized gift process. As Mauss argues in his discussion of primitive gift economies, modern notions of credit essentially are extensions of the gift: both distribute power and authority to forge social relations, and both function on the premise that a return is imminent and indeed due. ${ }^{22}$ Pierre Bourdieu also finds a homology between the obligatory gift and modern credit; both are

${ }^{20}$ Ibid, 13-14.

${ }^{21}$ Ibid.

${ }^{22}$ Marcel Mauss, The Gift: Form and Reason for Exchange in Archaic Societies, trans. W.D. Halls, (London: Routledge, 1990). 
an "attack on the freedom of one who receives it....it creates obligations."23 It is significant that while Burney attempts to critique a society that has become engrossed in an unstable economy of extended credit, the gift that is presented as an alternative economy is recast as credit and debt itself. Consequently, in Cecilia the impossible gift reinscribes the market economy of credit and debt even as Burney casts the heroine as a rational and responsible heiress who identifies wealth as an opportunity to mitigate others' hardships. Because the gift is impossible, Cecilia cannot avoid being implicated in a system of debt herself, even while she attempts to reconcile her mounting loss with a benevolent spirit. Although Cecilia's intentions are to assist the poor without bounds, her generosity places her in precarious financial situations. The power of the credit system consumes her charity within an illusion that is the motor of credit. Just as Harrel can engage in an illusion of wealth through credit's legitimization of a delayed return, Cecilia is caught up in the illusion that she can continually give without receiving returns and still maintain her status as heiress in control of her fortune. However, her gifts come to resemble in form and in rhetoric the credit system that pervaded 193.

\footnotetext{
${ }^{23}$ Pierre Boudieu, The Logic of Practice, trans. Richard Nice, (Stanford: Stanford University Press, 1977),
} 
the late eighteenth-century economy. ${ }^{24}$ The semblance of the logic of the gift in the novel and the logic of credit in the eighteenth century is not coincidental. Despite Burney's attempt to posit an alternative economy of selfless giving to an economy of consumption and credit, the gift merely denies the overt recognition of a specific return within a given period of time. In fact, the gift in Cecilia is a much more insidious exchange than the often vilified system of credit. ${ }^{25}$ The eighteenthcentury credit system was predicated on the legal articulation of the obligations entailed by giving and receiving. On the other hand, as is clear in Cecilia's acts of giving, gift exchange revolved around unspoken obligations mediated by a fantasy of equality and mutual concern. In this sense, the gift is a disguised process and the motor of the exchange is hidden by relations of friendship, kinship, and charity. The dynamics of credit and the gift are homologous except that credit is based on

\footnotetext{
${ }^{24}$ For details about the emergence of public credit in eighteenth century England and its implications on social and economic life, see Neil McKendrick, The Birth of a Consumer Society: The Commericaliztion of Eighteenth-Century England, (Bloomington: Indiana University Press, 1982), Peter Mathias, The Transformation of England, (New York: Columbia University Press, 1988), E. J. Hobsbawm, Industry and Empire,

(Harmondsworth, U.K.: Peguin, 1969), and D. E. C. Eversley, "The Home Market and Economic Growth in England, 1750-80," in

E .L. Jones and G. E. Mingay, eds. Land, Labour and Population in the Industrial Revolution (London: Edward Arnold, 1967).

${ }^{25}$ For contemporary responses to the dangers of credit see Samuel Johnson, The Letters of Samuel Johnson, ed. R. W. Chapman, 3 vols., (Oxford: Clarendon Press, 1952), Jonathan Swift, The History of the Four Last Years of the Queen, vol. 7 of The Prose Works of Jonathan Swift, ed. Herbert Davies et al., 14 vols., (Oxford: Blackwell, 1939-1968) and Alexander Pope, The Correspondence of Alexander Pope, ed. George Sherburn, 5 vols., (Oxford: Clarendon Press, 1956).
} 
legal and compulsory practices while gift exchange is misrecognized and the power relations it inscribes are disguised. Ironically, Cecilia is no better off as a charitable giver than she would be as a creditor. The gift is impossible precisely because it takes the form of credit that cannot be recognized as such. This is significant because by not recognizing the gift, the exchanges that should empower Cecilia as both a charitable citizen and compassionate friend are manipulated to increase her debt to a patriarchal imperative.

Burney's novel reinforces the homology between credit and gift exchange, illustrating also the harm that can befall the giver and the creditor. The relationship between gift and credit problematizes Cecilia's understanding of generosity. Despite her intentions, her acts of giving are always accompanied by a language of contract, credit, and debt. While her generosity may play itself out in her mind as a selfless gesture that does not anticipate a return, the realities of late eighteenth-century market economy repeatedly interfere with her good intentions. For example, when she identifies Mrs. Hill as a worthy recipient of her charity, she attempts to bestow more than she has available (she has not yet turned 21 and is living on an allowance), subsequently placing herself in debt through her generosity. Later, her gifts to Harrel accumulate to the point that she must draw on credit, thus implicating herself in the 
credit system that has destroyed the Harrels: she now owes the usurer and must borrow to repay that debt. The inability to distinguish between credit and gift is a central problem in Cecilia because it both encourages Cecilia to idealize her generosity while allowing the recipients to engage her not in charity, but in a network of debt.

The impossibility of the gift means that there can only be an account of the gift and of the desire that impels us to mislabel obligations as gift, even if, as Derrida suggests, "the gift were never anything but a simulacrum": there must be an account "of the possibility of this simulacrum and the desire that impels towards this simulacrum." ${ }^{26}$ Thus, in Cecilia, this account must present itself, I argue, as a narrative of unending obligation, as a narrative of familial and paternal obligation, specifically, an open-ended debt to a patriarchal ideology that ultimately demands the "restitution" of the female self to paternal authority. Therefore, while Cecilia's gifts ostensibly empower her as an agent in a feminized economy of charity, the gift simultaneously subverts this authority because it functions symbolically to bolster patrilineal succession and a socioeconomic ideology based on subordination and exploitation. By consistently aligning acts of gift exchange with scenes of

\footnotetext{
${ }^{26}$ Derrida, 12.
} 
violence and extortion, the novel effaces feminine moral and economic agency, thereby exposing benevolence as an inherently feminine form of obligation to a masculinist symbolic order.

\section{III.}

The first recipient in the novel, Cecilia begins her life as an heiress with a paternal debt: she owes an obligation to the "Father" for the independence that the system of inheritance allows her. Receiving this gift automatically obligates her to make a return because the gift ethic insists on repayment. While she immediately recognizes charitable donation as a means of recompense, she unknowingly repays her inheritance in other ways throughout the novel as those around her deplete her fortune through the demands of social customs that she cannot resist. In effect, her giving consistently is compelled by the pressures of a masculinist prerogative that regulates the economic system; her charity is recast as a debt to a patriarchal ideology and repaid only through her complicity in its networks of obligation and privilege, as well as in a system of credit and payment schedules. Because Cecilia's gifts of charity and "loans" must be subsumed within a system of exchange that requires a countergift in order to prevent her from attaining the idealized agency that the gift promises, the gifts are inscribed within a symbolic 
order and translated into an account of daughterly duty to the father. In other words, the "gift" is payment on a symbolic debt to a paternal ideology that never can be repaid and which demands Cecilia's total submission.

Cecilia fails to recognize that her inheritance places her in debt not to the poor but to the patrilineal structures that define her social and personal identity. Therefore, the money is never hers to give. Within the opening paragraphs of the novel, we learn that Cecilia, having received 10,0001. from her father and an estate of 30001 . per annum from her recently deceased uncle, not only is "indebted to fortune, [but that] to nature she had yet greater obligations" (1:6). Cecilia is endowed with financial independence, at least to the extent that the legacy from her father carries no overt restrictions on its use-it does, however, imposes on her the kinds of obligations to class and gender based notions of benevolence that Zunshine, Andrews, and Fowkes Tobin discuss. Concomitantly, she possesses elegance, liberality, and intelligence, commodities that should ensure her success in fashionable society and on the marriage market. On the brink of maturity, however, Cecilia experiences a familial, social, and economic crisis. Her father and her uncle dead, she is left with no male kin to authorize her entrance into the world, to exchange her in marriage, or for her to repay through her obedience to social custom. Moreover, her uncle's will 
inextricably links her patrimony to her social identity: a name clause insists on Cecilia's future husband "annexing her name" of Beverly or the inheritance will revert to a distant third cousin (1:6)-a restriction that ultimately will make the heroine's reintegration into domesticity violent and prolonged. Bereft of familial ties that would dictate her course in life, she finds herself wondering not as her novel predecessor Evelina does, "to whom I most belong," but to whom her money, and therefore her social identity, most belongs.

This identity crisis prompts Cecilia's philanthropic plan. However, as Catherine Gallagher points out, the novel asserts continually the indebtedness of single women and demonstrates that their socioeconomic identities are their only means of repayment; fortunes do not belong to women but are "property she holds in trust for her future husband."27 This indebtedness, though, does not enact itself in a particular moment, such as in marriage, but is an ongoing responsibility. The 'impossibility' of Cecilia's adequately reciprocating a gift traps her in a narrative that ultimately evades resolution. Her "scheme of happiness" ultimately is eroded by her perpetual debt. By the novel's conclusion, "the strong spirit of benevolence which had ever marked her character, was... no longer, as hitherto,

\footnotetext{
${ }^{27}$ Gallagher, 244.
} 
unbounded" (939). Cecilia's blunted spirit of benevolence represents what has been demonstrated throughout: Cecilia may be authorized to occupy a feminized space of generosity but she never is authorized to act or to give freely.

The masquerade episode reveals early in the novel the cultural conflict inherent in Cecilia's social position as a single woman and as an heiress with a name and fortune to give. Her fortune and autonomy situate her as a culturally conspicuous parodic male: her plain dress at the masquerade signifies the complicated dual role that the title of "heiress" entails by placing her simultaneously outside and within the confines of traditional systems of exchange. While she does not appear literally in masquerade dress, the scene dramatizes the process of unmasking Cecilia. Almost immediately after her arrival in the Harrel household she is thrust into a scene of conspicuous consumption as they prepare for an "at home" masquerade. The reckless spending at the masquerade proves an exemplary instance of the Harrels' extravagance and prefigures the pressures Cecilia will endure to give, donate, contribute, and lend. These pressures expose and eventually repair the cultural indiscretion in her uncle's will by stripping Cecilia of her fortune and reintegrating her into domesticity as a wife.

Furthermore, the masquerade foreshadows the love conflict 
that reduces Cecilia by the end of the novel to a "dejected and melancholy gift..."(623). That her inheritance is, essentially, Cecilia, an economic identity that makes her an exchangeable good, implicates her as an agent of exchange--more specifically, as an agent in her own exchange since her acts of giving have direct consequences on her value as an object. On one hand, by presenting her social role at the masquerade as heiress without disguise, Cecilia symbolically presents herself as a "gift," a commodity on the marriage market that inscribes her as an object to be bargained for rather than as an agent who controls how she will appear and function. Because the fortune left to her by both her father and uncle should secure a respectable husband for Cecilia, her inheritance relegates her to the position of commodity on the marriage market; she is, like all women, an object of exchange, and the inheritance she receives assigns her a specific value on that market. On the other hand, the inheritance enables her to give and embark on missions of charity and potentially to subvert the narrative that would force her to exchange herself. Where her money ends up, however, exposes the complexities that the gesture of the gift seeks to bury. Cecilia's economic transactions must necessarily take the form of gift-giving as a means to deflect her participation as both an agent and object of exchange in a repressive and competitive economic system. Through the performance of gift-giving, 
Cecilia's role as lender to Harrel and philanthropist to the Hills-distinctly masculine roles, as Zunshine and Andrews demonstrate, in eighteenth-century society-appears as an externally feminine form of obligation. As a woman, Cecilia must appear disinterested, even adverse to economic agency. Her role is not to exchange commodities one for the other but to be given passively as the object, and the marriage plot eventually overwhelms her schemes for disinterested generosity and erases her charitable agency. Cecilia's dual role is ultimately what subverts her benevolent agency. Her gifts, both compelled and seemingly given freely, actually undermine her authority over herself and her money so that the generous gestures that would give her independence work steadily throughout the novel to position her a dependent wife.

Although Cecilia herself is a 'gift' to be given, the love exchange between her and Mortimer becomes burdened with issues of debt: despite the seeming equality gift exchange presupposes, their love cannot be given freely and without incurring a loss. As Gayle Rubin makes clear, in order to participate in gift exchange, "one must have something to give;" however, women, as traditional objects of exchange for men, "are in no position to 
give themselves away."28 Moreover, the name clause in her uncle's bequest threatens the integrity of patrilineal succession by discupting familial and marital tradition. Therefore, the most important act of giving in the novel-Cecilia's giving up of her name-requires also that she give over her inheritance and her fantasy of autonomy. For Cecilia, the role of heiress not only signifies her coming into wealth but also the agency she attempts to assert through charitable donation. In order to sustain this agency, her husband must agree to take her last name of Beverly when she marries. Thus, the disruption of a traditional giftexchange ritual-the man gives his name, the woman's father or guardian a dowry-renders the fiction of exchange. In the case of Cecilia and Mortimer, the giving of one negates the possibility of the other. If Cecilia takes Mortimer's gift, her gift of money is revoked by the conditions of her uncle's will. If Mortimer takes Cecilia's name, then he does nothing but take, as that familial signifier-his name-is his right to confer on his wife only in exchange for her fortune. Moreover, the act of giving his name is an act of possession: to receive the "gift" of the Delvile family name, the heroine must surrender to Mortimer her social and economic agency. The tradition of the gift ultimately impedes the union and forces the most economically

\footnotetext{
${ }^{28}$ Gayle Rubin, "The Traffic in Women: Notes on the "Political Economy' of Sex," in Toward an Anthropology of Women, ed. Rayna Reiter (New York and London: Monthly Review Press, 1975), 173.
} 
transgressive act in the novel, the secret marriage. This dilemma reveals the impossibility of ethical gift-exchange even at a contractual level when the partners clearly know their obligations and have agreed to the terms. There is no equal gift exchange, no one instance when what is given by one is equivalent to what is given by the other. While Cecilia's financial loss resolves the ambiguity of her status by making her a socially sanctioned wife, it is not self-denial that enacts the reversion but the pressures of a patriarchal economy.

\section{IV.}

In a strategy that challenges the very nature of generosity, Burney repeatedly situates her heroine in moments of duress, therefore insisting her benevolent acts be read as forced responses to paternal aggression. Because the gift always is, in Bourdieu's terms, a misrecognition, Cecilia can never give from the disinterested motivations that serve as her moral guide; rather, the hostility, emotional manipulation, and selfdestruction that Burney links to the economic throughout Cecilia prevents the heroine from ever giving out of an idealized benevolence. Rarely does she experience the anticipated bliss that accompany her daydreams of charity: "...now she supported an orphan, now softened the sorrows of a widow.... The prospect at 
once exalted her hopes and enraptured her imagination" (1:55). Her gestures to the Hills reward her with only a brief sense of gratification. Instead, Cecilia consistently attempts to justify her gifts while simultaneously trying to force herself into believing in the worthiness of her recipients:

She had now parted with 80501 . to Mr. Harrel, without any security when or how it was to be paid; and that ardor of benevolence which taught her to value her riches merely as they enabled her to do good and generous acts, was here of no avail to console or reward her, for her gift was compelled, and its receiver was all but detested (271).

Each time Cecilia attempts to mediate familial and economic conflict by giving over money, she invariably becomes the victim, not the savior: "The soothing recompense of succouring benevolence, followed not this gift, nor made amends for its loss"(383). Her belief that she gives to help others merely masks the underlying corruption of the system which depends on self-interest and productive exploitation. The rhetoric of the gift from Cecilia to Harrel succeeds in cloaking Harrel's manipulation of her compassion and over-zealous generosity when he threatens suicide: "'you have stopt me,' said he, in a voice 
scarce audible, 'at the very moment I had gathered courage for the blow: but if indeed you will assist me, I will shut this up,-if not, I will steep it in my blood!"" (266). Driven to desperation by Harrel's threat, Cecilia agrees hastily to do "all-any-everything" he asks (266). While she ultimately reconciles her complicity in her own exploitation by describing the exhorted money as a "donation"(270) and "gift" (271), the transaction is nothing more than a paternal demand on her economic identity as a means to redeem Harrel from ruin. In effect, the gift reproduces itself as debt. Rather than enabling Harrel finally to subvert the burdens of the credit system, Cecilia's generosity places her in debt and at the mercy of others: "Cecilia turned from [Harrel] in horror; and with a faltering voice and heavy heart, entreated Mr. Arnott to settle for her with the Jew" (271). By having to borrow money against her own future inheritance, Cecilia's gift incorporates her within a system of debt rather than a network of charity-a debt that Cecilia will discover revolves around continual loss and ultimate subjection.

Both Harrel and Albany exploit the coercive nature of gift exchange by insisting that Cecilia give while they themselves refuse to engage in the structure of reciprocal obligation that gift exchange entails. Albany, with "vehemence and authority," demands Cecilia "seek the virtuous, relieve the poor"(68), but he 
fails to acknowledge that his idealized notion of charity requires she get nothing in return, an omission that eventually contributes to her financial ruin. He coerces Cecilia through verbal assault and guilt so that even generosity becomes exploitative--another gift that is compelled:

Thou hast lost a faithful old friend, a loss which with every setting sun thou may'st mourn, for the rising sun will never repair it! But was that a reason for shunning the duties of humanity? Was the sight of death a motive for neglecting the claims of benevolence? Ought it not rather to have hastened your fulfilling them? (746-747).

Cecilia clearly can never give enough, but Albany demonstrates that her giving has moral consequences; he judges her moral value on her willingness to give: "Frivolous, unmeaning, ever ready excuses! . .what business is so important as the relief of a fellow- creature?... again thou failest me?" (747). Albany's rant shows that his investment in Cecilia's charity is a paternal and coercive investment and that her duty to benevolence is a duty to him as well. His insistence that she consistently attend to objects of charity, even if this means she ignore the loss of a close, maternal companion, emphasizes the lack of options 
Cecilia has as a wealthy and single heiress: if she does not pay heed to her duty of giving away her money, then she fails both as a moral agent and as an indebted ward. Albany and Harrel, therefore, succeed in exhorting money from Cecilia on the basis of a paternal authority that can continually measure and pass judgement on Cecilia's moral worth.

The internalization of the ideology of the gift likewise provokes Mrs. Delvile to pressure both Cecilia and Mortimer out of trying to transgress the aristocratic rules of patrilineal succession. Appalled at Mortimer's intention of marrying Cecilia and taking her name, Mrs. Delvile accuses Mortimer of trying to subvert this most valued of exchanges by threatening the status of the Delvile name: "How will the blood of your wronged ancestors rise into your guilty cheeks, and how will your heart throb with secret shame and reproach, when wished joy upon your marriage by the name of Mr. Beverly!" (677). The construction of marriage as a form of gift exchange ensures that the inequities of gender exploitation appear voluntary and equally beneficial; however, the gift does not presuppose equality, it simply disguises inequality. Because this inequality works in favor of aristocratic paternalism, Mrs. Delvile's behavior demonstrates the extent to which women must internalize the manipulative realities of the gift. On the one hand, the traditional marriage exchange promises to preserve for the Delviles an aristocratic 
lineage. On the other hand, Mortimer's potential marriage to Cecilia threatens the collective fantasy that disguises the true contradictions of a society that uses women as symbolic gestures of benevolence. As a result, Mrs. Delvile too must resort to threats, and Mortimer blatantly accuses her of manipulating Cecilia's duty to propriety: "You will exhort from her a promise to see me no more" (680). While Harrel can use threats to control Cecilia and self-inflicted violence to evade his creditors, Mrs. Delvile relies on the gift to prevent overt violence to herself. Her involuntary self-affliction shows that relinquishing the fantasy of the gift creates the potential for uncontrollable and unwarranted violence towards women. Without the symbolic gesture of the gift-the collective fantasy of equal exchange-the violent realities to which females are subjected become real. Ironically, Mrs. Delvile's hemorrhage finally secures for her, temporarily, Mortimer's obedience. Her attack becomes a violent extortion that mirrors Harrel's earlier manipulation. This time, Cecilia gives over her name and identity to save Mrs. Delvile through the perpetuation of aristocratic lineage, just as she relinquished earlier her economic independence to save Harrel. 
If in non-western societies gift exchange, ideally, was a way to construct and affirm a variety of interpersonal and social relationships, then in capitalist society the gift acts as means to deny and conceal economic injustices that lie at the heart of the social and economic system. Cecilia offers a circuitous route to blame by invoking the rhetoric of a gift economy to deflect responsibility and disguise bad behavior. The men surrounding Cecilia, both her guardians and her suitors, consistently are rendered impotent or infantile in their attempts to perform properly in the economic sphere and to assure paternal authority: Harrel is a spendthrift, Briggs is a miser, Albany, despite his invoking of Christian theology, is an abusive exploiter, and Delvile is a fading aristocrat who depends on his son's marriage to avoid slipping into upper-class penury. Cecilia's suitors eye the heroine for what she can offer in the most basic form of gift-exchange-marriage. Sir Robert Floyer agrees to marry Cecilia in a deal that promises to bring him a fortune in exchange for releasing Harrel from a gambling debt, a debt he is unable to recover by any other means; her childhood friend Monckton has "long looked upon her as his future property" (9) and believes he can court Cecilia through the pressures of debt: "he was glad in making her owe him an obligation"(438). Similarly, the Delviles too depend on the tradition of giving the husband's name in marriage as a means of repairing their finances 
and sustaining symbolically an aristocratic image that they cannot otherwise support economically.

Just as Cecilia is read within the novel by fashionable society as a female philanthropist who resists classification, Cecilia's guardians struggle with the burdens of masculine propriety. Most specifically, Harrel attempts to hide the fact that he does not have money by continually spending and publicly displaying his diminishing and then borrowed wealth. His exploitation of the obligations of gift exchange that Cecilia has internalized enables him to keep his creditors temporarily at bay and to postpone suffering publicly the consequences of his financial mismanagement. His hollow promises to pay back Cecilia's "gifts" serve to invoke the gesture of the gift, to imply a circular pattern of gift and repost, and consequently disguise from his fashionable friends his inability to function responsibly in an economic system that demands masculine superiority. The money he owes to the Hills, while an obviously tragic transgression in Cecilia's eyes, goes practically unnoticed by Harrel's family as the debt repeatedly is relegated outside to the competitive economic sphere of legal obligations and usurious interest payments. Only Cecilia's persistent championing of the Hills' cause and Arnott's generous "loan" eventually rights the wrong. Cecilia's repeated loans demonstrate her investment in the fiction of the gift as a way to 
rescue a morally corrupt system. At the same time that the creditors close in on Harrel's estate in an attempt to redeem their loans, he uses Cecilia to redeem his character when faced with bankruptcy and humiliation. Harrel, who does anything but give, finds temporary salvation in the practice of gift-exchange as a means by which to deflect blame for his financial irresponsibility. The impossibility of the gift authorizes Harrel's repeated deferral of a return as well as his habitual denial of the need to reciprocate. Unlike the gifts given to Mrs. Harrel-who is able to extort money from Cecilia on the basis of a nostalgic childhood friendship-the gift between Cecilia and Harrel is not between friends but between a daughter and a father, between one who owes a debt continually and one who never is expected to repay. Cecilia's money is not hers to give but for her guardians to regulate and exploit. Hence, Cecilia's "gift" does not arise out of an autonomous act that signifies her agency in economic exchange but rather as the payment of an openended debt concealed as both a loan and a gift.

Likewise, Albany, who verbally abuses Cecilia into parting with her money through gifts of assistance, is driven not by a genuine sense of sympathy for the poor or a natural inclination to benevolence, but by guilt. After breaking a marriage vow to a fifteen-year old girl of a lower class, Albany revels in his newly attained paternal inheritance only to find later that by 
abandoning the girl he has forced her into a clandestine affair, prostitution, and her untimely death. As a means of alleviating his overwhelming guilt, Albany converts himself into a philanthropist. But the purpose of his gift-giving is two-fold. Not only does he attempt to rid himself of guilt, he also secures himself in a masculine economic tradition as a giver, or as one who has an abundance to give. For Albany, gift-giving reinstates the fallen into positions of power-determining who will receive his gifts of charity and who will not-thus covering up his moral and spiritual defects with an idealized masculine economic authority.

Burney repeatedly aligns financial transgressions with gender transgressions and deviations within gendered spaces. The heroine's coerced gifts draw Cecilia into the contemporary dialogue concerning female value and domesticity that pervaded the eighteenth-century conduct books. By having the spendthrift Harrel implicate Mrs. Harrel in the indulgence which led to their ruin, Burney offers an account not only of the dissipated male but of the irresponsible domestic woman. Harrel is shown attempting to mitigate his own poor judgment by blaming his wife for ill-managing the domestic economy. As Nancy Armstrong explains, late eighteenth-century conduct books repeatedly located the domestic woman's ability to manage the household 
economy as the primary factor in determining her value. ${ }^{29}$ While the husband's role was to bring in capital, the woman's role was to regulate it, thus adding value to his labors of accumulation. Although Mrs. Harrel follows her husband's profligate lead, her spending is a transgression of cultural expectations. Her husband's participation in the economic sphere is a distinctly male activity while her disregard for financial moderation stands out as a violation within the private sphere, a violation her husband can justifiably condemn:

A good wife perhaps might have saved me,--mine, I thank her! tried not. Disengaged from me and my affairs, her own pleasure and amusements have occupied her solely. Dreadful will be the catastrophe she will see to-night; let her bring it home, and live better (431).

In his own mind and within the code of eighteenth-century domesticity, Harrel rightly targets Mrs. Harrel as having ruined him by neglecting her wifely duty. It is not surprising, therefore, that Harrel looks to Cecilia for recourse as the creditors close in. He immediately recognizes Cecilia as both an economic and domestic asset. Early in the novel, she stands out

\footnotetext{
${ }^{29}$ Nancy Armstrong, Desire and Domestic Fiction: A Political History of the Novel (New York: Oxford University Press, 1989).
} 
as a voice of reason directly in opposition to Mrs. Harrel. All too quickly, however, Cecilia's role as a financially independent woman becomes a way to manage not just Harrel's economic crises but his crisis of identity. His inability to give in any exchange, whether it be the repayment of a debt or the reciprocation of a gift, ultimately emasculates him. As merely a receiver, Harrel is powerless in the system and only the heroine's money enables him to perform his social role of the wealthy male who controls and manipulates money-a role that must publicly disguise the loan as a gift, even as it forces Cecilia into debt.

\section{$V I$.}

Benevolence in Cecilia becomes a form of social obligation, a demand on one's personal and socioeconomic identity. The work of Cecilia is to take back what belonged to the father and insist on a return with interest, the added value the daughter has acquired as an heiress. Thus, the first half of the novel extorts her money and the second half her independence. Cecilia is an heiress only because there is a failure in the male line: there are no male heirs to inherit her father's and uncle's estates so it goes to Cecilia only by default and only temporarily-her inheritance, in effect, is a loan. While the 
reinstatement of Cecilia into a domestic space seemingly nullifies her father's and uncle's gifts, these gifts ironically secure patriarchal order. The novel unmasks the paternal gift as a loan that eventually must be paid back to her husband's family. While the route is circuitous, what rightly belongs to the Father returns to the Father: Cecilia's inheritance pays for Harrel's loses, repairs the capitalist oversight that renders the Hills at Harrel's mercy, and transfers the Beverly name and fortune to a distant male relative when Cecilia marries. Ultimately, Cecilia's fortune and identity are returned symbolically to the Father when she is reintegrated into society as a dependent object. Despite the absence of a real father and the too obvious presence of inept paternal substitutes, the Law of the Father systematically reasserts itself until the heroine is properly reinstated into a domestic role.

Before her reintegration into private life, however, Cecilia suffers precisely for her presumption of economic independence. Eventually, her own sanity is added to the list of returns she makes throughout the novel. The secret marriage culminates in her complete loss of agency and her recourse to a socially sanctioned authority figure fo help. After running mad through the streets of London in search of Mortimer, certain he is near death at the hands of Belfield in a duel, she loses her purse and is taken in by the owners of a pawnshop. Her crazed, amnesic, 
and penniless state is a precise metaphor for the dependent condition of married women and the asymmetrical nature of the gift. While the fiction of the gift implies equality, Cecilia's marriage shows clearly that gift exchange in fact takes from women their social identity and potential independence without a sufficient return: "No one will save me now! I am married, and no one will listen to me! ill were the auspices under which I gave my hand. Oh it was a work of darkness, unacceptable and offensive" (903). Cecilia's loss of sanity, as Gray-Cutting notes, coincides with a promotion of her own self-interest: her commitment to Mortimer in a marriage disproved of by her guardians and his parents. The "ruling order of reason" is obscured when Cecilia strays from the "female standard of benevolence and self-sacrifice" that is demanded as the only appropriate female passion (40). Even after she is rescued by Albany and returned to the paternalist fold, she continues to pay interest on her debt; she must disguise her passion in the "transparency of sincerity and care," (40) living a domestic life that is "imperfect" and only with "cheerful resignation" (941).

If the partners in a gift exchange, as I have argued in my chapters on foreign trade, Roxana, and Tom Jones, forge complex familial, economic, and political relationships, then intergender giving should result in the securing of male/female relations, most especially if it is a woman who gives. The 
inherent refusal of the economic system to acknowledge feminine agency in transactions calls into question the very relations the gift supposedly affirms. Thus, despite the tendency on the part of early modern economic theory to feminize gift exchange, the gift ultimately maintains a patrilineal and repressive economic system. ${ }^{30}$ Clearly, Cecilia's gifts do little to seal a bond between herself and her male guardians or to change the lives of the lower and middle-class objects of her charity. In fact, the gifts further alienate Cecilia while solidifying the symbolic paternal authority of the males surrounding her. As a result, her acts of gift-giving appear not as moments of disinterested generosity but as instances of the coercion that redeems an ideology of crass economic self-interest under the rubric of symbolic familial obligation and gendered authority. The ultimate gift, the debt that Cecilia must pay, forces her to surrender her fortune, sanity, and social identity. The demands of the male recipients are finally insatiable: the female self is the gift, who in marriage and domesticity, must keep on giving.

\footnotetext{
${ }^{30}$ For analyses of the gift and feminine economy see Helen Cixous, "Sorties: Out and Out: Attacks/Ways Out/Forays," and Luce Irigaray, "Women on the Market," both reprinted in Alan D. Schrift, ed., The Logic of the Gift: Toward an Ethic of Generosity (New York: Routledge, 1997).
} 


\section{Works Cited}

Andrew, Donna T. Philanthropy and Police: London Charity in the Eighteenth Century

Princeton: Princeton University Press, 1989.

Armstrong, Nancy. Desire and Domestic Fiction: A Political History of the Novel. New York: Oxford University Press, 1989.

Barbon, Nicholas. A Discourse of Trade. London, 1690.

Barrow, John. Travels in China. London, 1804.

Bataille, Georges. "The Notion of Expenditure" in Visions of Excess: Selected Writings, 19271939. Trans. Allan Stoekl, with Carl R. Lovitt and Donald M. Leslie Jr. Minneapolis: University of Minnesota Press, 1985.

Battestin, Martin. "Fielding's Definition of Wisdom: Some Functions of Ambiguity and Emblem in Tom Jones." ELH, 35 (1968).

Bellamy, Liz. Commerce, Morality, and the Eighteenth-century Novel. Cambridge: Cambridge University Press, 1998.

Bourdieu, Pierre. The Logic of Practice. Trans. Richard Nice. Cambridge: Polity Press, 1990.

Braverman, Richard. “Capital Relations and The Way of the World.” ELH 52.1 (1985): 133-58.

Burney, Frances. Cecilia; or Memoirs of an Heiress. Ed. Peter Sabor and Margaret Anne Doody New York: Oxford University Press, 1988.

Campbell, D. Grant. "Fashionable Suicide: Conspicuous Consumption and the Collapse of Credit in Frances Burney’s Cecilia." Studies in Eighteenth-Century Culture, vol 20 (1990). 
Castle, Terry. Masquerade and Civilization: The Carnivalesque in Eighteenth-Century English Culture and Fiction. Stanford: Stanford University Press, 1986.

Chaudhuri, K.-N. Asia before Europe: Economy and Civilization of the Indian Ocean from the Rise of Islam to 1750. Cambridge: Cambridge University Press, 1990.

Cixous, Helen. "Sorties: Out and Out: Attacks/Ways Out/Forays." Ed. Alan D. Schrift. The Logic of the Gift: Toward an Ethic of Generosity. New York: Routledge, 1997.

Congreve, William. The Way of the World. Ed. Brice Harris, Restoration Plays. New York, NY: The Modern Library, 1953.

Defoe, Daniel. Roxana; or the FortunateMistress. Ed. Robert Clark. London: Orion Publishing Group, 1998.

Derrida, Jacques. Given Time. 1. Counterfeit Money. Trans. Peggy Kamuf. Chicago: University of Chicago Press, 1992.

Durant, David. "Roxana’s Fictions.” Studies in the Novel, vol. 13 (1993).

Elison, George. Deus Destroyed: The Image of Christianity in Early Modern Japan. Cambridge: Harvard University Press, 1973.

Evelyn, John. Navigation and Commerce, Their Original and Progress. London, 1674.

Eversley, D. E. C. “The Home Market and Economic Growth in England, 1750-80," in Eds. E .L. Jones and G. E. Mingay. Land, Labour and Population in the Industrial Revolution. London: Edward Arnold, 1967.

Fairbank, J. K. "Tributary Trade and China's Relations with the West." Far Eastern Quarterly 1 
(1942), 129-49.

Farrington, Anthony, ed. The English Factory in Japan, 1613-23. London: British Library, 1991.

Fielding, Henry. Tom Jones: The History of a Foundling. Ed. Sheridan Baker. New York: W. W. Norton \& Company, 1995.

Finn, Margot. The Character of Credit: Personal Debt in English Culture, 1740-1914 Cambridge: Cambridge University Press, 2003.

Fowkes-Tobin, Beth. Superintending the Poor: Charitable Ladies and Paternal Landlords in British Fiction 1770-1860. New Haven: Yale University Press, 1993.

Frank, Andre Gunder. ReOrient: Global Economy in the Asian Age. Berkeley and Los Angeles: University of California Press, 1997.

Gabbard, Christopher. “The Dutch Wives' Good Husbandry: Defoe's Roxana and Financial Literacy.” Eighteenth Century Studies, vol. 37 (2004).

Gallagher, Catherine. Nobody's Story: The Vanishing Acts of Women Writers in the Marketplace, 1670-1820. Berkeley: University of California Press, 1994.

Gernet, Jacques. China and the Christian Impact: A Conflict of Cultures. Trans. Janet Lloyd. Cambridge: Cambridge University Press, 1985.

Gregory, C. A. Gifts and Commodities. London: Academic Press, 1982.

Hamilton, Alexander. A New Account of the East Indies. 2 vols. Edinburgh, 1727.

Harrison, Bernard. Henry Fielding's Tom Jones: The Novelist as Moral Philosopher. London: Sussex University Press, 1975. 
Hendry, Joy. "To Wrap or not to Wrap." Man. New Series 24 (1989)

Henley, W. E., ed. The complete works of Henry Fielding, Esq. New York: 1967.

Hevia, James. Cherishing Men from Afar: Qing Guest Ritual and the McCartney Embassy of 1793. Durham: Duke University Press, 1995.

Hey, John. Fellow of Sidney Sussex College, Cambridge, 1777.

Hill, Christopher. Puritism and Revolution. London: Secker and Warburgh, 1958.

Hobsbawm, E.J. Industry and Empire. Harmondsworth, U.K.: Peguin, 1969.

Hummel, William E. “'The Gift of my Father's Bounty': Patriarchal Patronization in Moll Flanders and Roxana." Rocky Mountain Review of Language and Literature, vol. 48:2 (1994).

Ides, Evret Ysbrants. Three Years Travels from Moscow Over-Land to China. London, 1706.

Ingrassia, Catherine. Authorship, Commerce, and Gender in Early Eighteenth-century England: A Culture of Paper Credit. Cambridge: Cambridge University Press, 1998.

Irigaray, Luce. "Women on the Market." Ed. Alan D. Shrift. The Logic of the Gift: Towards and Ethic of Generosity. New York: Routledge, 1997.

Jacobson, Susan L. "A Dialogue of Commerce: Defoe's Roxana as Mistress and Entrepreneur." Compendious Conversations: The Method of Dialogue in the Early Enlightenment. Ed. Kevin Cope. Frankfurt: Anglo-American Studies: vol. 4, (1992).

Jensen, Lionel. Manufacturing Confucianism: Chinese Traditions and Universal Civilization. Durham: Duke University Press, 1997.

Johnson, Samuel. The Letters of Samuel Johnson. Ed. R. W. Chapman, 3 vols. Oxford: Clarendon 
Press, 1952.

Jordan, W. K. The Charities of London 1480-1660: The Aspirations and the Achievements of the Urban Society. London: Ruskin House, 1960.

Kaempfer, Engelbertus. The History of Japan. Trans. J. G. Scheuchzer. London, 1727.

Keay, John. The Honourable Company: A History of the English East India Company. New York: Macmillan, 1991.

Keohane, Catherine. "“Too Neat for a Beggar,' Charity and Debt in Burney's Cecilia," Studies in the Novel, 33 (winter, 2001): 379-401.

Klekar, Cynthia. "'Her Gift was Compelled': Gender and the Failure of the Gift in Cecilia." Eighteenth-Century Fiction, forthcoming.

Langford, Paul. Public Life and the Propertied Englishman: 1689-1798. Oxford: Clarendon Press, 1991.

Lillo, George. The London Merchant. ed. Lincoln Faller in The Broadview Anthology of Restoration and Eighteenth-Century Drama. Gen. Ed J.Douglas Canfield. Peterborough, Ontario: 2001.

Macartney, Lord George. An Embassy to China, ed. J.L. Cranmer-Byng. Archon Books, Hamden: 1963.

Markley, Robert. "Civility, Ceremony, and Desire at Beijing: Sensibility and the European Quest for 'Free Trade' with China in the Late Seventeenth Century." Passionate Encounters in a Time of Sensibility. Ed. Anne Mellor and Maximilian Novak. Newark: University of 
Delaware Press, 2000, 60-88.

. "Riches, Power, Trade, and Religion: The Far East and the English Imagination, 1600-1720." Renaissance Studies 17 (2003).

Marx, Karl. The Critique of Capitalism. Ed. Robert E. Tucker. The Marx-Engels Reader, $2^{\text {nd }}$ ed. New York: W.W. Norton \& Company Inc, 1978.

Massarella, Derek. A World Elsewhere: Europe's Encounter with Japan in the Sixteenth and Seventeenth Centuries. New Haven: Yale University Press, 1990.

Mathias, Peter Mathias. The Transformation of England. New York: Columbia University Press, 1988.

Mauss, Marcel. The Gift: The Form and Reason for Exchange in Archaic Societies. Rpt. New York: Norton, 2000.

McAdam, E.L., Jr.and George Milne, eds., Johnson's Dictionary. New York: Pantheon Books, 1963.

McClure, Ruth. Coram's Children: The London Foundling Hospital in the Eighteenth Century New Haven: Yale University Press, 1971.

McKendrick, Neil. The Birth of a Consumer Society: The Commericaliztion of EighteenthCentury England. Bloomington: Indiana University Press, 1982.

McKeon, Michael McKeon. The Origins of the English Novel: 1660-1740. Baltimore: Johns Hopkins University Press, 2002.

Milton, Giles. Samurai William: The Adventurer Who Unlocked Japan. London: Hodder and 
Stoughton, 2002.

Morse, Hosea B. The Chronicles of the East India Company Trading to China 1635-1834, 5 vols. Oxford: Clarendon, 1926-29.

Nieuhoff, Jan. An Embassy from the East-India Company of the United Provinces, to the Grand Tartar Cham Emperor of China; Delivered by their Excellencies Peter de Goyer, and Jacob De Keyzer, At his Imperial City of China. Trans. John Ogilby. London, 1669.

Novak, Maximillan E. Daniel Defoe: Master of Fcitions. Oxford: Oxford University Press, 2001.

Osteen, Mark, ed. The Question of the Gift: Essays Across Disciplines. New York: Routledge, 2002.

Pocock, J.G.A. The Ancient Constitution and the Feudal Law: English Historical Thought in the Seventeenth Century. Cambridge: Cambridge University Press, 1957. . Politics, Language, and Time: Essays on Political Thought and History (New York, NY: Antheneum, 1971.

Pomeranz, Kenneth. Europe, China, and the Making of the Modern World Economy. Princeton: Princeton University Press, 2000.

Pope, Alexander. The Correspondence of Alexander Pope. Ed. George Sherburn, 5 vols. Oxford: Clarendon Press, 1956.

Porter, David. Ideographia: The Chinese Cipher in Early Modern Europe. Stanford: Stanford University Press, 2001.

Porter, Roy. "The Gift Relation: Philanthropy and Provincial Hospitals in eighteenth-century 
England," in The Hospital in History Lindsay Granshaw and Roy Porter, eds. London: Routledge, 1989: 149-78.

Proust, Jacques. Europe through the Prism of Japan. Trans. Elizabeth Bell. Notre Dame: Notre Dame University Press, 2002.

Rexroth, Kenneth. “Tom Jones.” The Saturday Review. (1968) 13-15. Reprinted in Tom Jones: A Norton Critical Edition. Ed. Sheridan Baker. New York: W. W. Norton \& Company, 1995.

Rothenstein, Eric. "Virtues of Authority in Tom Jones." The Eighteenth Century 28.2 (1987).

Rubin, Gayle. "The Traffic in Women: Notes on the 'Political Economy' of Sex." Toward an Anthropology of Women. Ed. Rayna Reiter. New York and London: Monthly Review Press, 1975.

Saris, John. The First Voyage of the English to Japan. Ed. Takanobu Otsuka. Tokyo: The Toyo Bunko [The Oriental Library], 1941.

Saussy, Haun. Great Walls of Discourse and Other Adventures in Cultural China. Cambridge: Harvard University Press, 2001.

Schmidgen, Wolfram. Eighteenth-Century Fiction and the Law of Property. Cambridge: Cambridge University Press, 2002. . "Illegitimacy and Social Observations: The Bastard in the Eighteenth-Century Novel.” ELH 69.1 (2002).

Schrift, Alan D., ed. The Logic of the Gift: Toward an Ethic of Generosity. New York: 
Routledge, 1997.

Sherman, Sandra. Finance and Fictionality in the Early Eighteenth Century: Accounting for Defoe. Cambridge: Cambridge University Press, 1996.

Shesgreen, Sean. "The Moral Function of Thwakum, Square, and Allworthy." Studies in the Novel, 2 (1970).

Smith, Adam. The Wealth of Nations. Books I-III. Ed. Andrew Skinner. Rev. ed. New York: Penguin, 1999.

Spacks, Patricia Meyers. Desire and Truth: Functions of Plot in Eighteenth-century English Novels. Chicago: University of Chicago Press, 1990.

Spence, Jonathan D. The Chan's Great Continent: China in Western Minds. New York: Norton, 1998.

Straub, Kristina. Divided Fictions: Fanny Burney and Feminine Strategy. Lexington: University Press of Kentucky, 1987.

Stewart, Maaja A. "Ingratitude in Tom Jones." Journal of English and Germanic Philology, vol. 89 (1990).

Swift, Jonathan. The History of the Four Last Years of the Queen, vol. 7 of The Prose Works of Jonathan Swift. Ed. Herbert Davies et al., 14 vols. Oxford: Blackwell, 1939-1968. Thompson, James. Models of Value: Eighteenth-century Political Economy and the Novel. 
Durham: Duke University Press: 1996.

Waley-Cohen, Joanna. The Sextants of Beijing: Global Currents in Chinese History. New York: Norton, 1999.

Wills, John E., Jr. Pepper, Guns, and Parleys: The Dutch East India Company and China, 16621681. Cambridge: Harvard University Press, 1974.

Wills, John E., Jr. Embassies and Illusions: Dutch and Portuguese Envoys to K'ang-hsi, 16671687. Cambridge: Council on East Asian Studies, Harvard University, 1984.

Wong, R. Bin. China Transformed: Historical Change and the Limits of European Experience. Ithaca: Cornell University Press, 1997.

Zemon Davis, Natalie. The Gift in Sixteenth-Century France. Madison: The University of Wisconsin Press, 2000.

Zizek, Slavo. The Sublime Object of Ideology. Verso, 1989.

Zonitch, Barbara. Familar Violence: Gender and Social Upheaval in the Novels of Frances Burney. Newark: University of Delaware Press, 1997.

Zunshine, Lisa. "The Gender Dynamics of the Infanticide Campaign in Eighteenth-Century England and Richardson's History of Sir Charles Grandison" in Writing British Infanticide: Child Murder, Gender, and Print, 1722-1859, ed. Jennifer Thorn. Newark: University of Delaware Press, 2003. . Bastards and Foundlings: Illegitimacy and its Representations in Eighteenth- 
Century England. Columbus: Ohio State University Press, 2005. 